\title{
Investigation of the palladium-catalysed cyclisation of $\alpha$-amido malonates with propargylic compounds
}

\author{
Sean R. Barlowa , Lily J. Callaghan ${ }^{a}$, and Vilius Franckevičius ${ }^{a}{ }^{*}$ \\ aDepartment of Chemistry, Lancaster University, Lancaster LA1 4YB, UK
}

\begin{abstract}
The palladium-catalysed cyclisation of propargylic electrophiles with nucleophiles represents a useful synthetic approach for the rapid construction of heterocyclic building blocks. However, these cyclisation reaction processes often pose a number of challenges due to the need for the simultaneous control of chemo-, regio- and stereoselectivity. Herein, we disclose the discovery of $\alpha$-amido malonates as novel bis-nucleophiles in the highly chemo- and regioselective, as well as moderately enantioselective, palladium-catalysed cyclisation with propargylic compounds to afford a broad range of functionalised dihydrooxazine heterocycles. The new dihydrooxazine products will expand the suite of heterocycles available to medicinal chemists, and prompt the investigation of unchartered bis-nucloeophiles in palladium-catalysed cyclisation reactions en route to novel classes of heterocycle.
\end{abstract}

Introduction. Aromatic and aliphatic heterocycles are highly prevalent structural motifs in small molecule drugs and biologically active compounds, ${ }^{1}$ and expedient synthetic access to heterocycles remains an active area of research. ${ }^{2}$ Aromatic heterocycles, rich in $\mathrm{sp}^{2}$ centres and structurally flat, have historically been particularly common due to the availability of robust and efficient methods for their synthesis and functionalisation. ${ }^{3}$ However, more recent studies indicate that the use of building blocks possessing higher levels of saturation can contribute to lower attrition rates during drug development. ${ }^{4}$ In addition, a greater degree of saturation in heterocycles results in enhanced 3D shape diversity, thus, enabling more efficient sampling of chemical and biological space. ${ }^{5}$ As the synthesis of functionalised saturated heterocycles is more challenging due to the introduction of chiral centres, there is increasing interest in the development of new chemical methods to procure stereoselectively substituted heterocycles. ${ }^{6}$

In order to access heterocycles with unique substitution patterns, we sought to harness the reactivity of propargylic compounds under palladium catalysis (A, Scheme 1). Oxidative addition of palladium( 0 ) to propargylic electrophile 1 affords a $\pi$-propargylpalladium(II) species $2 .{ }^{7}$ Hard nucleophiles then typically undergo either propargylation (3) or allenylation (4) processes by addition to one of the termini of $2 .^{8}$ In contrast, soft nucleophiles tend to react via a double addition mechanism, affording products 5 in which one equivalent of the nucleophile has undergone alkenylation, and one, allylic alkylation. ${ }^{9}$ The latter reactivity pathway becomes relevant to heterocycle synthesis if the two nucleophiles are tethered, resulting in cyclic products 6 . 


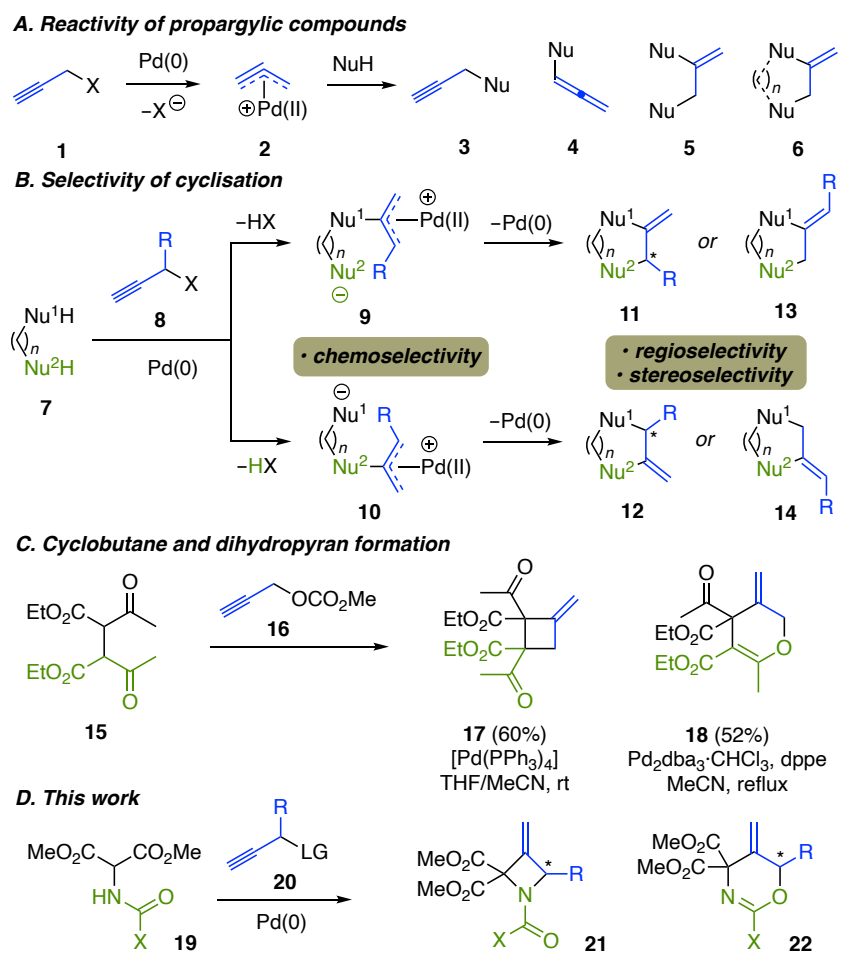

Scheme 1. Cyclisation reactions with propargylic electrophiles.

Indeed, by utilising tethered bis-nucleophiles 7 , in which at least one of the two nucleophiles is a heteroatom, in a palladium-catalysed reaction with propargylic electrophile $\mathbf{8}(\mathrm{B}$, Scheme 1), cyclisation reactions can be invoked, leading to a range of heterocycles. ${ }^{10}$ However, for such a cyclisation to be successful, the control of chemo-, regio- and stereoselectivity may be required. Chemoselectivity arises from the order of addition of nucleophiles. If both nucleophiles are identical and bis-nucleophile 7 is symmetrical, then the order of alkenylation and allylic alkylation is inconsequential, as illustrated in the synthesis of 1,4benzodioxins, ${ }^{11}$ piperazines, ${ }^{12}$ and medium-ring heterocycles. ${ }^{13}$ In contrast, when the two nucleophiles are different, or if the nucleophiles are identical but the physical tether is not symmetrical, then appropriate bias needs to be present to enable selective initial addition of one of the two nucleophiles (9 vs 10). Several strategies have been implemented to control chemoselectivity by ensuring sufficient difference in acidity, ${ }^{12,14}$ whereby the first anion made is the first to react, exploiting differences in nucleophilicity, ${ }^{9 a, 9 b, 15}$ introducing sufficient steric bias, ${ }^{12}$ or specifically generating one of the nucleophiles by means of decarboxylation. ${ }^{16}$ Following the selective addition of the first nucleophile, the conjugate acid of the second nucleophile then needs to be acidic enough to undergo deprotonation and, thus, facilitate intramolecular allylic alkylation with $\pi$-allylpalladium(II) electrophile $\mathbf{9}$. Nevertheless, if propargylic electrophile $\mathbf{9}$ is substituted, regioselectivity of allylic alkylation becomes important. Addition at the more substituted position in $\pi$-allylpalladium(II) electrophiles 9 or 10 would afford products 11 or 12 , respectively, and addition at the less substituted end would give products 13 or 14, respectively. Alkylation at the more hindered end to afford 11 or 12 is more common for electronic reasons, $11 \mathrm{a}, 11 \mathrm{~b}, 12,14 \mathrm{a}, 14 \mathrm{c}, 14 \mathrm{~d}, 15 \mathrm{a}, 15 \mathrm{~b}, 15 \mathrm{~h}, 16$ presumably due to better stabilisation of positive charge at the more substituted centre in the $\pi-$ allylpalladium(II) cation, ${ }^{11 c, 17}$ but may also result in alkylation at the less substituted terminus for steric reasons. ${ }^{13,15 e-9}$ Regioselectivity of alkylation can also depend on the nature of the substituents, ${ }^{11 \mathrm{e}-\mathrm{g}}$ ligand effects, reaction temperature, ${ }^{12,15 \mathrm{c}}$ and product ring size. ${ }^{18}$ In addition to regioselectivity, the allylic alkylation step of a substituted $\pi$-allylpalladium(II) cation necessitates the control of stereoselectivity. Concerning the formation of products 11 or $\mathbf{1 2}$, 
in the presence of chiral ligands for palladium, allylic alkylation has been shown to successfully install the chiral allylic centre with high levels of enantioselectivity at the electrophile, ${ }^{11 b, 11 d-f, 14 b, 19}$ or the chiral centre at the prochiral nucleophile. ${ }^{14 f, 14 g, 15 d}$ If the alkylation step is regioselective for the formation of 13 or 14 , each of which contains a substituted alkene, the preferred configuration of the alkene is typically $Z$ due to the syn geometry of the $\pi$-allylpalladium(II) complex unless syn-anti isomerisation is present for steric reasons. ${ }^{20}$

A further regioselectivity aspect has to be taken into account if the allylic alkylation step can give rise to two potential ring sizes due to the ambident nature of the nucleophile, such as enolates, ${ }^{9 a, 9 b, 15 a, 15 \mathrm{~h}}$ enamines, ${ }^{15 b}$ indoles, ${ }^{14 \mathrm{~g}}$ phenols, ${ }^{15 \mathrm{f}}$ and naphthol, ${ }^{15 \mathrm{~g}}$ typically affording the most stable product. Lu et al. explored this type of regioselectivity through the use of a symmetrical bis-nucleophile 15, in which two b-ketoesters are tethered by a $\mathrm{C}-\mathrm{C}$ bond $(\mathrm{C}$, Scheme 1). ${ }^{21}$ It was found that, depending on the catalyst and solvent employed, cyclisation at room temperature led to the selective formation of kinetic cyclobutane product 17 via enolate $C$-allylic alkylation, whereas an elevated reaction temperature afforded thermodynamic dihydropyran 18 via O-allylic alkylation.

Inspired by this report, we sought to investigate novel $\alpha$-amino malonate bis-nucleophiles of type 19 in palladium-catalysed cyclisation reactions that could give rise to azetidine and dihydrooxazine nitrogen heterocycles 21 and 22, respectively (D, Scheme 1). We reasoned that, by employing an appropriate $N$-protecting group in 19 and identifying suitable reaction conditions, either $\mathrm{N}$-allylic alkylation to azetidine $\mathbf{2 1}$, or $\mathrm{O}$-allylic alkylation to dihydrooxazine 22 could become selective. The challenges with this approach are the simultaneous control of chemoselectivity to ensure the correct order of addition of the nucleophiles, regioselectivity that installs an allylic chiral centre, stereoselectivity that enables enantiocontrolled construction of that centre, as well as regioselectivity in terms of kinetic vs thermodynamic product formation. The successful control of these selectivity aspects would pave the way to flexibly functionalised heterocycles with novel substitution patterns.

\section{Results and Discussion.}

\section{Effect of N-protecting group}

Our study began with the synthesis of bis-nucleophiles 23,24 and $25 a$, bearing a sulfonamide, carbamate and amide functionality, respectively (Figure 1), by means of $N$ protection of $\alpha$-amino dimethylmalonate. ${ }^{22}$ Sulfonamide 23 was expected to undergo cyclisation to afford an azetidine, whereas carbamate and amide 24 and 25a, respectively, could in principle give rise to either 4- or 6-membered products due to the presence of a carbonyl functionality in the protecting group.

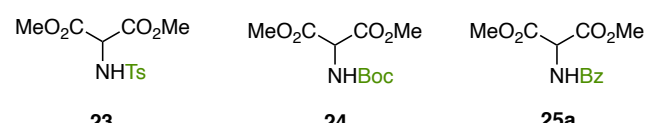

Figure 1. $N$-protected a-amino malonate bis-nucleophiles.

Our investigation into the propensity of cyclisation of malonate-amine bis-nucleophiles with propargylic electrophiles commenced by reacting tosyl-protected substrate $\mathbf{2 3}$ with propargylic carbonate $\mathbf{2 6}$ under palladium catalysis in THF at an ambient temperature (Scheme 2). Given that $\mathbf{2 3}$ is a sulfonamide, the cyclisation should lead to the formation of azetidine 27. Unfortunately, the use of $\mathrm{Pd}\left(\mathrm{PPh}_{3}\right)_{4}$ as the catalyst, as well as a screen of 
several large bite-angle ligands, including dppe, dppp, dppf, Xantphos, DPEphos and BINAP, resulted in no reaction taking place. In order to promote cyclisation, the same catalysts were employed in refluxing THF as the reaction solvent; unfortunately, predominantly decomposition was observed in all cases. Although the sulfonamide anion has the capacity to undergo intramolecular allylic alkylation as a nucleophile, it is also a relatively good leaving group, potentially making the formation of strained $\mathbf{2 7}$ reversible at an elevated temperature.

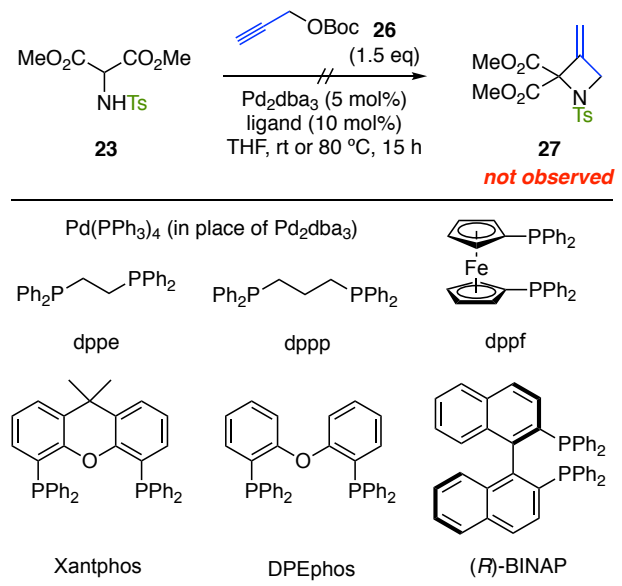

Scheme 2. Unsuccessful cyclisation of Ts-protected 23.

In contrast to sulfonamide $\mathbf{2 3}$, the cyclisation of carbamate $\mathbf{2 4}$ was expected to lead to two potential products (Table 1): Boc-protected azetidine $\mathbf{2 8}$ as the kinetic product via $\mathrm{N}$-allylic alkylation, or 6-membered carbamate 29 as the thermodynamic product arising from $\mathrm{O}$ allylic alkylation. Under all conditions tested, we were not able to isolate either of the two heterocycles irrespective of reaction temperature. Instead, a substantial amount of homocoupled product $\mathbf{3 0}$, resulting from double addition of the enolate of $\mathbf{2 4}$, was formed. At room temperature, the extent of homocoupling was highly dependent on the ligand for palladium. The effect of a higher reaction temperature served only to facilitate the homocoupling of 24. Whilst dppe as the ligand was much less effective (entry 1), Xantphos, $\mathrm{Pd}\left(\mathrm{PPh}_{3}\right)_{4}$ and $(R)$-BINAP readily mediated the formation of $\mathbf{3 0}$ (entries 2-4), whereas dppp, $\mathrm{dppf}$ and DPEphos led to quantitative homocoupling (entries 5-7), as observed by ${ }^{1} \mathrm{H}$ NMR spectroscopy. 
Table 1. Homocoupling of Boc-protected 24. ${ }^{\text {a }}$

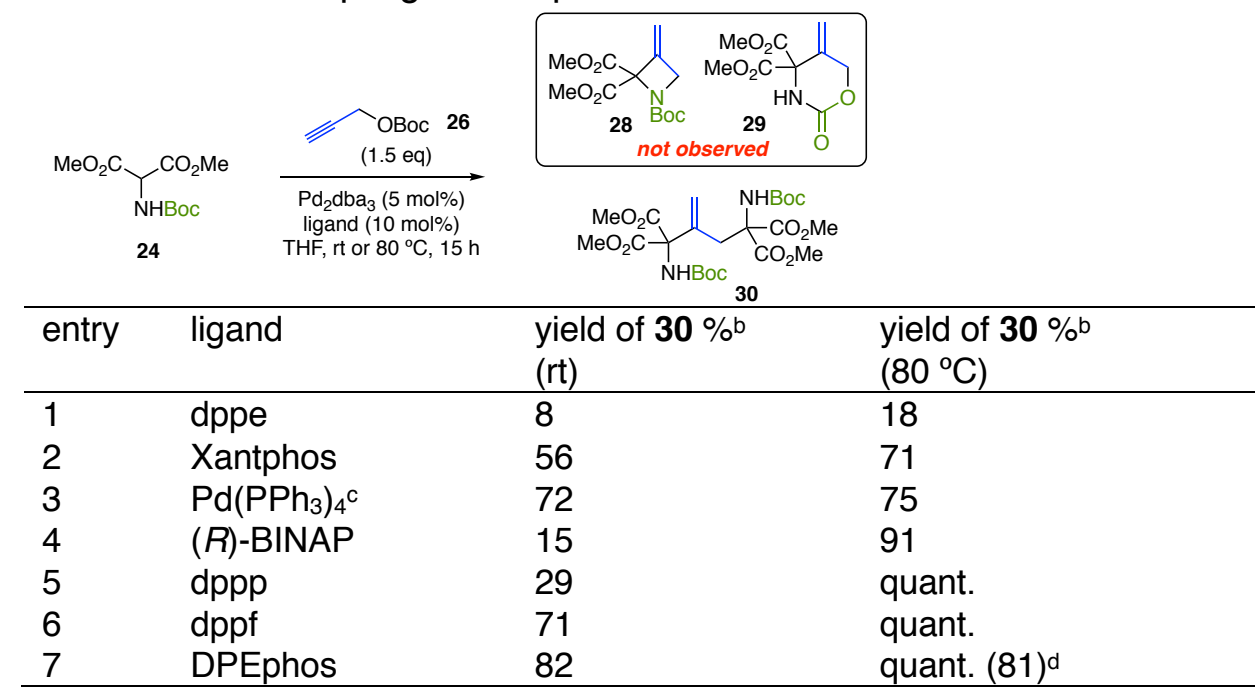

aReactions were performed on $0.2 \mathrm{mmol}$ scale.

bYield determined by ${ }^{1} \mathrm{H}$ NMR spectroscopy of the crude product mixture using 1,3,5trimethoxybenzene as the internal standard.

cUsed in place of $\mathrm{Pd}_{2}(\mathrm{dba})_{3}$.

dYield of isolated $\mathbf{3 0}$.

Finally, benzamide 25a was found to display reactivity that was different from that of both sulfonamide 23 and carbamate 24 (Table 2). We first attempted the cyclisation at room temperature in order to promote regioselective cyclisation via the nitrogen atom to afford azetidine $\mathbf{3 1}$ as the kinetic product. Again, the formation of $\mathbf{3 1}$ could not be detected with a range of ligands for palladium. Instead, homocoupled product $\mathbf{3 2}$ was formed with high efficiency in the majority of cases (entries 1-7). However, we also observed trace quantities of 6-membered dihydrooxazine 33a (entries 1, 6 and 7), arising from intramolecular $O$-allylic alkylation. By performing the reaction at an elevated temperature in THF with $\mathrm{Pd}\left(\mathrm{PPh}_{3}\right)_{4}$ as the catalyst, as well as dppe, dppp and $(R)$-BINAP as the ligands for palladium, marginally higher amounts of 6-membered heterocycle 33a were observed by ${ }^{1} \mathrm{H}$ NMR spectroscopy (entries 8-11). Formation of 33a was more efficient with dppf and DPEphos as the ligands (entries 12 and 13). The highest yield of 33a was obtained with Xantphos as the ligand where homocoupling was much less prevalent (entry 14). Reaction time could also be reduced from $15 \mathrm{~h}$ to $1 \mathrm{~h}$ with little detriment to the yield of $33 \mathrm{a}$ (entry 15). Finally, we found the reaction to be scalable and $33 \mathrm{a}$ was isolated in $63 \%$ yield on $2 \mathrm{~g}$ scale (entry 16). The order of addition of nucleophiles in this cyclisation arises from the higher acidity of the malonate than the amide in $\mathbf{2 5 a}$, resulting in selective deprotonation and, thus, chemoselective alkenylation of the enolate, followed by $O$-allylic alkylation of the amide. 
Table 2. Cyclisation of benzamide 25a. ${ }^{a}$

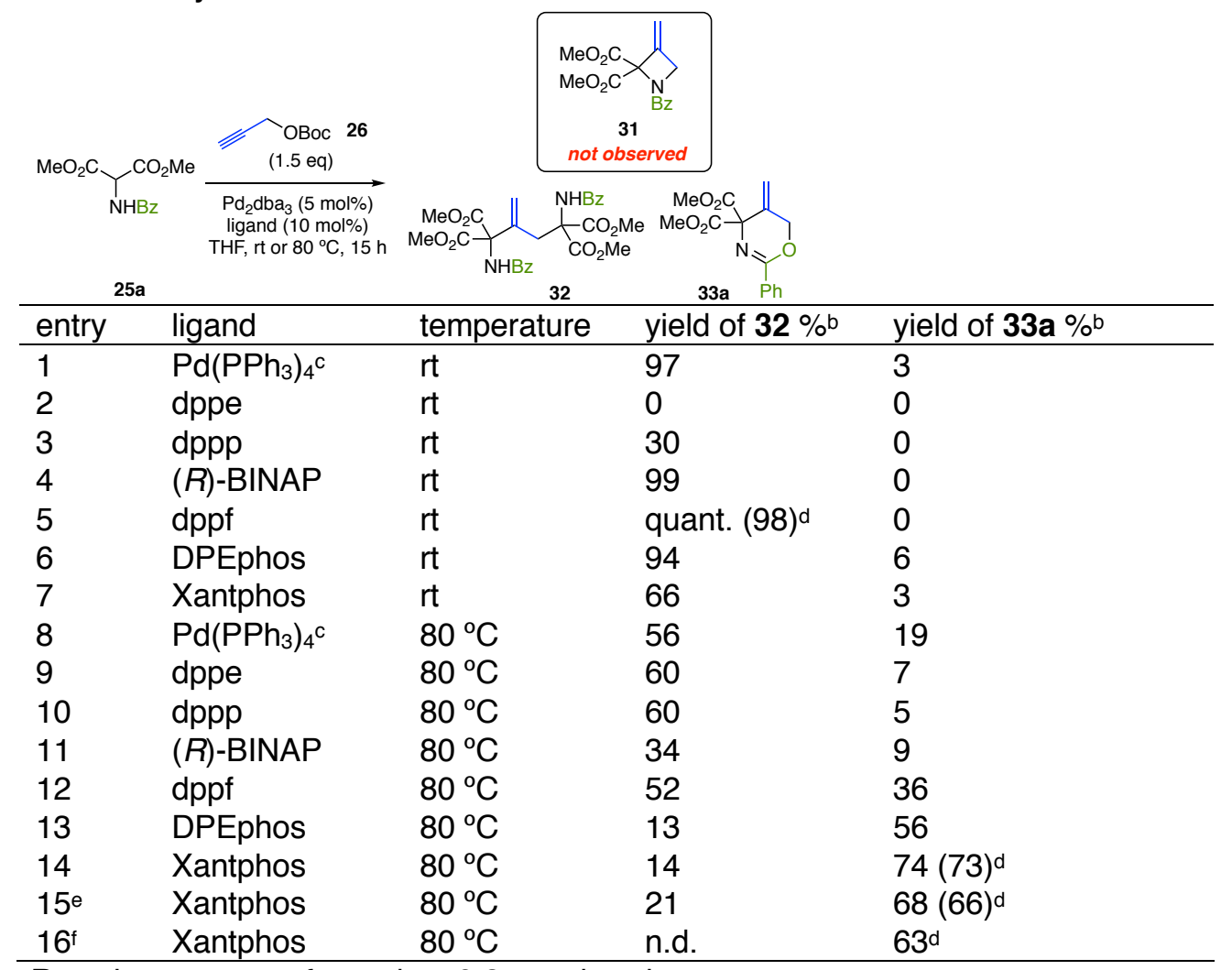

aReactions were performed on $0.2 \mathrm{mmol}$ scale.

bYield determined by ${ }^{1} \mathrm{H}$ NMR spectroscopy of the crude product mixture using 1,3,5trimethoxybenzene as the internal standard.

cUsed in place of $\mathrm{Pd}_{2}(\mathrm{dba})_{3}$.

dYield of isolated product.

eReaction time was $1 \mathrm{~h}$.

fReaction performed on $2 \mathrm{~g}$ scale.

To test whether formation of homocoupled $\mathbf{3 2}$ is a reversible process under palladium(0) catalysis and whether $\mathbf{3 2}$ could be converted to cyclic product $\mathbf{3 3 a}$, we re-subjected $\mathbf{3 2}$ to the same reaction conditions at an elevated temperature (Scheme 3 ). No reaction took place and linear 32 was re-isolated, suggesting that homocoupling of 25a is an irreversible reaction even at $80^{\circ} \mathrm{C}$.
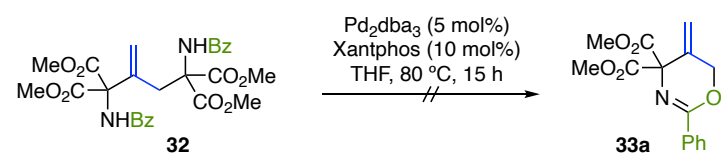

Scheme 3. Lack of reactivity of homocoupled 32.

\section{Cyclisation of $\alpha$-amido malonates}

Having established suitable reaction conditions for the cyclisation of malonate-amide bisnucleophile 25a with propargyl carbonate 26 to dihydrooxazine 33a, we next sought to investigate the substrate scope of this reaction (Table 3 ). In this context, a range of amides $\mathbf{2 5}$ were reacted with propargyl carbonate $\mathbf{2 6}$ under the optimised reaction conditions. 
Table 3. Amide scope investigation. ${ }^{a}$

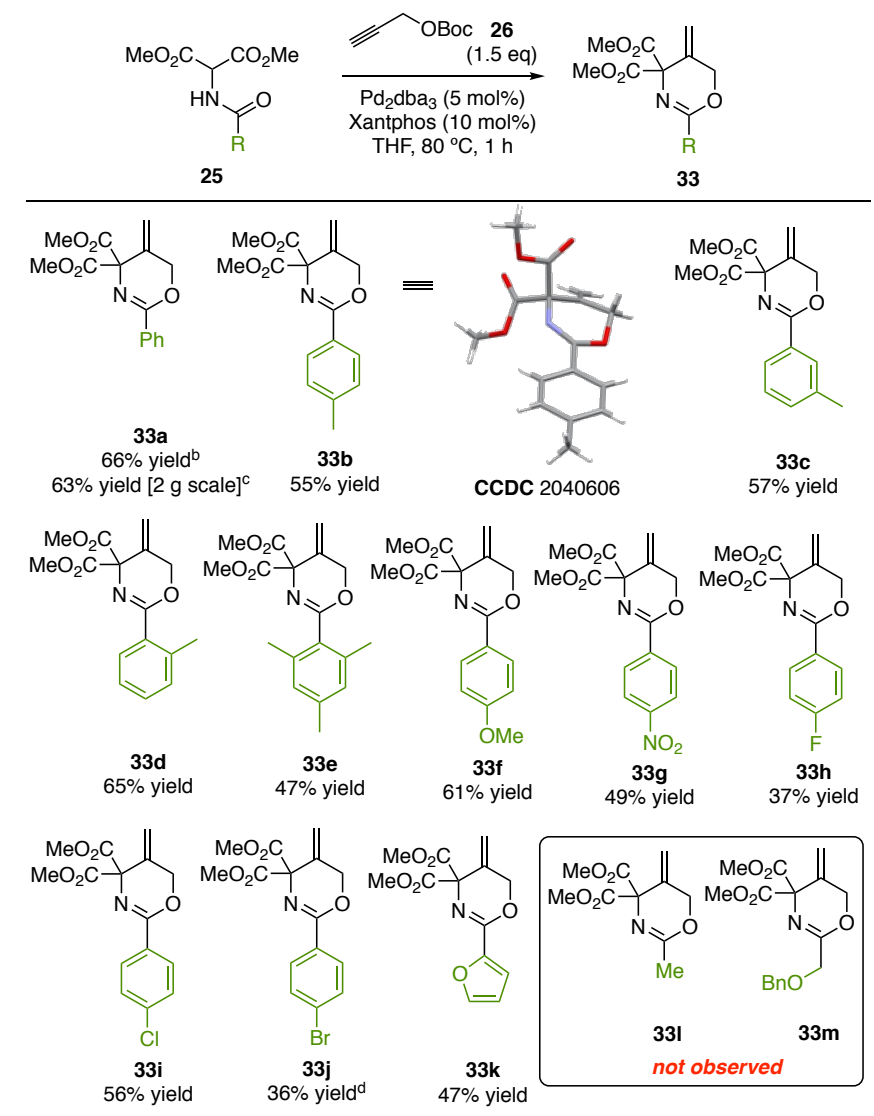

aReactions were performed on $0.2 \mathrm{mmol}$ scale.

bYield of isolated 33.

cReaction time was $15 \mathrm{~h}$.

dReaction performed in $\mathrm{CH}_{2} \mathrm{Cl}_{2}$ at $60^{\circ} \mathrm{C}$ for $15 \mathrm{~h}$.

All starting amides 25 were consumed within $1 \mathrm{~h}$, but due to the presence of some homocoupling of $\mathbf{2 5}$, the yields of product $\mathbf{3 3}$ were moderate to good in most cases. Tolylsubstituted substrates 25b-d afforded the desired heterocycles 33b-d in 55-65\% yield. An Xray structure of $\mathbf{3 3 b}$ was also obtained. ${ }^{23}$ Even more hindered mesityl $33 \mathbf{e}$ was isolated in moderate yield. Both para-electron-donating and withdrawing groups were tolerated in $\mathbf{3 3 f}$ and $\mathbf{3 3} \mathbf{g}$. The cyclisation to fluorinated $\mathbf{3} 3 \mathrm{~h}$ was less efficient compared to para-chlorosubstituted 33i. Brominated product 33j was only obtained by running the reaction in $\mathrm{CH}_{2} \mathrm{Cl}_{2}$ in low yield, presumably due to competing oxidative addition of palladium to the $\mathrm{C}-\mathrm{Br}$ bond. The reaction scope was also extended to heterocyclic $\mathbf{3 3 k}$, which was isolated in moderate yield. Unfortunately, alkyl-substituted amides did not undergo cyclisation to $33 \mathrm{I}$ and $\mathbf{3 3} \mathrm{m}$.

The substrate scope with respect to the substitution of the propargylic electrophile was explored next. The cyclisation of benzamide 25a with methyl-bearing electrophile 34a was performed under the optimised reaction conditions in refluxing THF with a longer reaction time of $15 \mathrm{~h}$ to ensure complete conversion (Scheme 5). The desired heterocycle 35a was isolated in good yield and as a single regioisomer with $O$-allylic alkylation taking place exclusively at the more substituted allylic terminus, presumably due to greater positive charge stabilisation at the more substituted position in the $\pi$-allylpalladium(II) cation. Unfortunately, in addition to $\mathbf{3 5 a}$, diene $\mathbf{3 7}$, resulting from b-hydride elimination, ${ }^{24}$ was also formed. However, by simply changing the reaction solvent to $\mathrm{CH}_{2} \mathrm{Cl}_{2}$, the formation of byproduct $\mathbf{3 7}$ was suppressed and $\mathbf{3 5 a}$ isolated in $88 \%$ yield. 


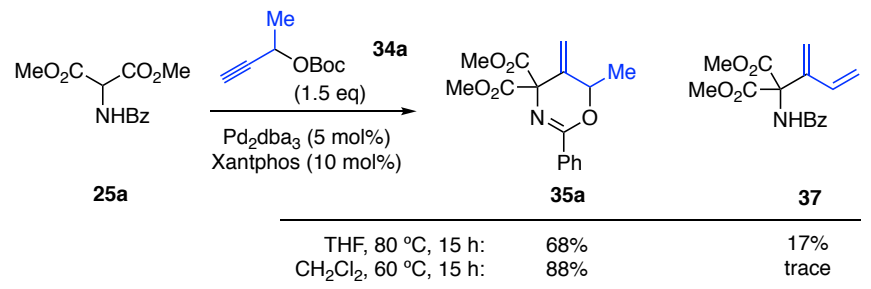

Scheme 5. Cyclisation with substituted electrophile 34a.

Using these conditions, the cyclisation reaction of 25a with other alkyl-substituted electrophiles $\mathbf{3 4}$ was attempted (Table 4). In most cases, the desired products $\mathbf{3 5}$ were isolated in significantly higher yields than $\mathbf{3 3}$ (vide supra, Table 3), as homocoupling and bhydride elimination were fully suppressed. It is also noteworthy that all reactions were completely regioselective for allylic alkylation at the more hindered position. In this context, linear aliphatic substituents in 35a-c were successfully installed in high yield, and an X-ray crystal structure of $35 \mathrm{a}$ verified the chemo- and regioselectivity of cyclisation. ${ }^{23}$ Benzyl- and thioether-bearing $\mathbf{3 5 d}$ and $\mathbf{3 5 e}$, respectively, were also readily formed. Side-chain branching in $\mathbf{3 5 f}$ did not negatively affect the reaction. More sterically hindered cyclohexyl and piperidyl examples $\mathbf{3 5 g}$ and $\mathbf{3 5 h}$, respectively, were also isolated in high yields. Surprisingly, reactions to cyclopropyl and isopropyl products $35 \mathbf{i}$ and $\mathbf{3 5} \mathbf{j}$, respectively, were lower yielding. More sterically encumbered propargylic electrophiles proved challenging: bulky tertbutyl group bearing $\mathbf{3 4 k}$, as well as tertiary carbonates $\mathbf{3 4 I}$ and $\mathbf{3 4 m}$, failed to react.

Table 4. Alkyl-substituted propargylic electrophile scope. ${ }^{a}$

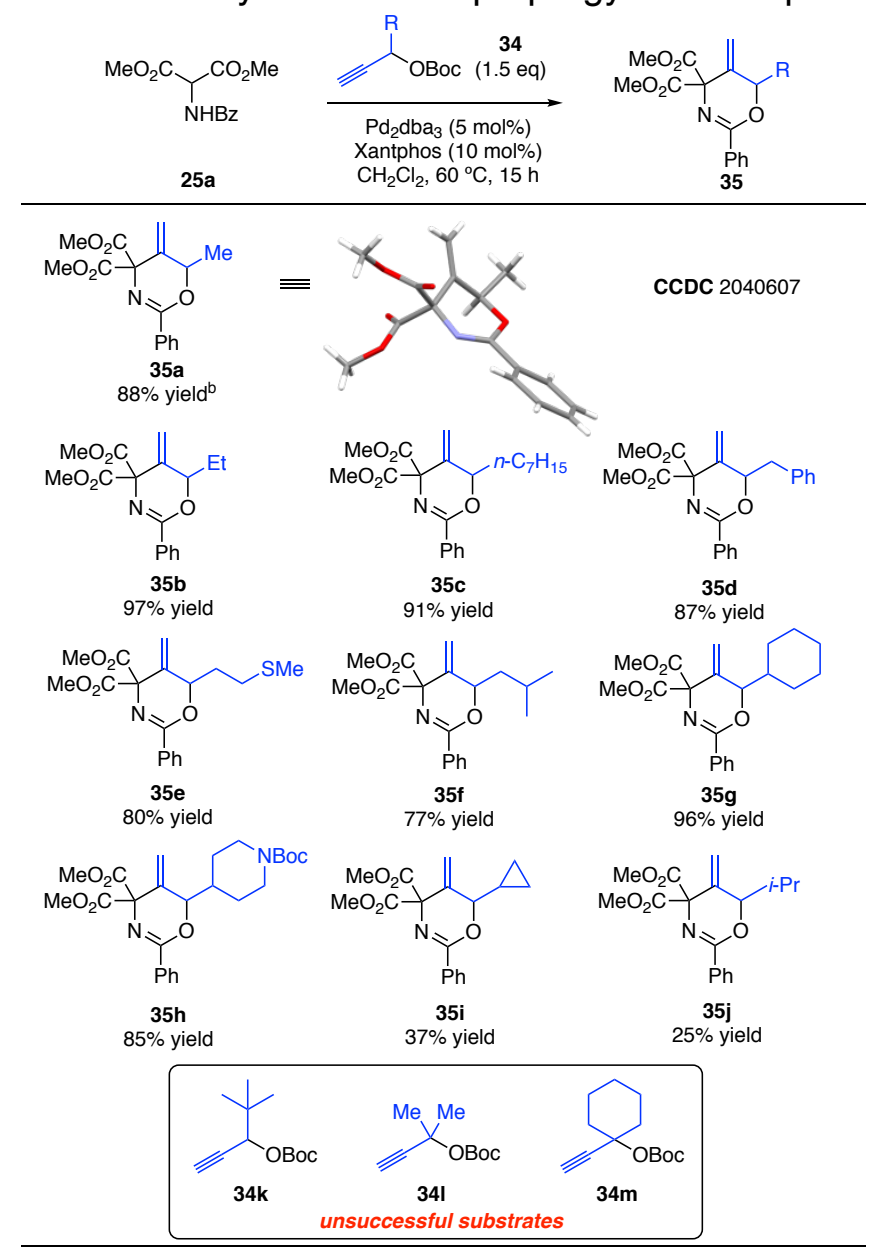

aReactions were performed on $0.2 \mathrm{mmol}$ scale.

bYield of isolated 35. 
While the cyclisation of benzamide 25a with alkyl-substituted propargylic carbonates $\mathbf{3 4}$ was found to be completely regioselective, this observation did not hold true for the cyclisation of 25a with phenyl-substituted electrophile 34n (Table 5). Specifically, when a ligand screen was performed in THF as the solvent, both $35 \mathrm{n}$ and its regioisomer $36 \mathrm{n}$ were formed in most cases, as observed by ${ }^{1} \mathrm{H}$ NMR spectroscopy. It was found that dppe did not mediate the reaction (entry 1 ), whereas reactions with dppp and $(R)$-BINAP as the ligands were low yielding with selectivity in favour of undesired isomer 36n (entries 2 and 3). Reaction with Xantphos as the ligand gave a reaction marginally in favour of 35n (entry 4), whereas DPEphos afforded a higher yield of 35n (entry 5). To explore whether the selectivity of the cyclisation and, therefore, the yield of $35 \mathrm{n}$, could be improved by varying the reaction solvent, a set of standard solvents were tested with DPEphos as the ligand. The outcome was indeed found to be highly dependent on the solvent. Toluene and 1,4-dioxane improved the ratio of products somewhat (entries 6 and 7), but a significant enhancement in reaction selectivity was seen in $\mathrm{CH}_{2} \mathrm{Cl}_{2}$ (entry 8). Although MTBE afforded by far the best selectivity (entry 9), 1,2-DCE gave the best balance of selectivity and yield (entry 10), providing $35 \mathrm{n}$ in $87 \%$ isolated yield. For comparison, we also applied the reaction conditions that had been found to be optimal for the cyclisation of alkyl-substituted carbonates (entry 11), and found that, although the regioselectivity was excellent, the yield of isolated 35n was lower.

Concerning the alkene geometry in undesired isomer $\mathbf{3 6 n}$, the $\pi$-allylpalladium(II) complex appears to have undergone a syn-anti isomerisation prior to cyclisation in order to avoid severe steric interactions between the phenyl and the malonate substituents.

Table 5. Cyclisation with phenyl propargyl carbonate $34 n .^{2}$

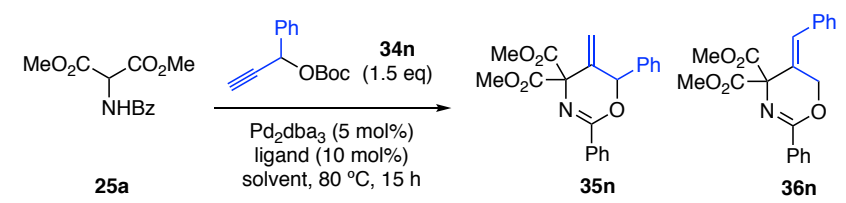

\begin{tabular}{lllll}
\hline entry & ligand & solvent & 35n : 36nc & yield of 35n \%d \\
\hline 1 & dppe & THF & - & 0 \\
2 & dppp & THF & $1: 2.5$ & 6 \\
3 & $(R)$-BINAP & THF & $1: 3.1$ & 15 \\
4 & Xantphos & THF & $1.2: 1$ & 37 \\
5 & DPEphos & THF & $1.2: 1$ & 50 \\
6 & DPEphos & toluene & $1.4: 1$ & 42 \\
7 & DPEphos & $1,4-d i o x a n e$ & $1.9: 1$ & 54 \\
$8 \mathrm{~b}$ & DPEphos & $\mathrm{CH}_{2} \mathrm{Cl}_{2}$ & $5.9: 1$ & 83 \\
$9 \mathrm{~b}$ & DPEphos & $\mathrm{MTBE}_{10}$ & $14: 1$ & $89(79)^{\mathrm{e}}$ \\
10 & DPEphos & $1,2-\mathrm{DCE}$ & $8.9: 1$ & $89(87)^{\mathrm{e}}$ \\
$11^{\mathrm{b}}$ & Xantphos & $\mathrm{CH}_{2} \mathrm{Cl}_{2}$ & $>19: 1$ & $77(73)^{\mathrm{e}}$ \\
\hline
\end{tabular}

aReactions were performed on $0.2 \mathrm{mmol}$ scale.

bReaction performed at $60^{\circ} \mathrm{C}$.

cRatio determined by ${ }^{1} \mathrm{H}$ spectroscopy of the crude product mixture.

dYield of $35 \mathrm{n}$ determined by ${ }^{1} \mathrm{H}$ NMR spectroscopy of the crude product mixture using $1,3,5$ -

trimethoxybenzene as the internal standard.

eYield of isolated $35 n$.

With optimal conditions for the regioselective cyclisation of benzamide 25a with phenylsubstituted propargylic carbonate $\mathbf{3 4 n}$ in hand, the stage was set to investigate the generality of this process with other carbonates $\mathbf{3 4}$ (Table 6), and a variety of aryl substituents were found to be well-suited in this cyclisation. More specifically, the regioselectivity of cyclisation with strongly electron-rich para-methoxy-substituted $\mathbf{3 4 0}$ to $\mathbf{3 5 0}$ 
was as high as that of $\mathbf{3 5 n}$. Although formation of dimethoxy-substituted $\mathbf{3 5 p}$ was less selective, the yield of the desired isomer was still good. Weakly electron-donating methyl substituents paved the way to good yields of products $\mathbf{3 5 q}$ and $\mathbf{3 5 r}$, albeit the regioselectivity of the formation of ortho-substituted $35 \mathrm{r}$ was moderate. Heterocycle $35 \mathrm{~s}$, bearing an electron-withdrawing ester, was also formed in good yield. Halogen substituents were readily incorporated, resulting in the formation of $35 \mathrm{t}$ and $35 \mathrm{u}$ with good selectivity and in high yield. Unfortunately, tertiary aryl-substituted carbonates $\mathbf{3 4 v}$ and $\mathbf{3 4 w}$ did not undergo cyclisation, likely due to steric effects. Although electron-donating substituents should lead to better stabilisation of the positive charge at the more substituted position in the $\pi$-allylpalladium(II) intermediate, ${ }^{11 c}$ and result in a more selective cyclisation in favour of 35 , we did not observe a definitive trend in this study. For example, 35p and 35s were formed with similar regioselectivity despite the contrasting electronic properties of the substituents, whereas $35 \mathbf{u}$ was obtained with high selectivity despite the electron-withdrawing nature of fluorine.

Table 6. Aryl-substituted propargylic electrophile scope. ${ }^{a}$

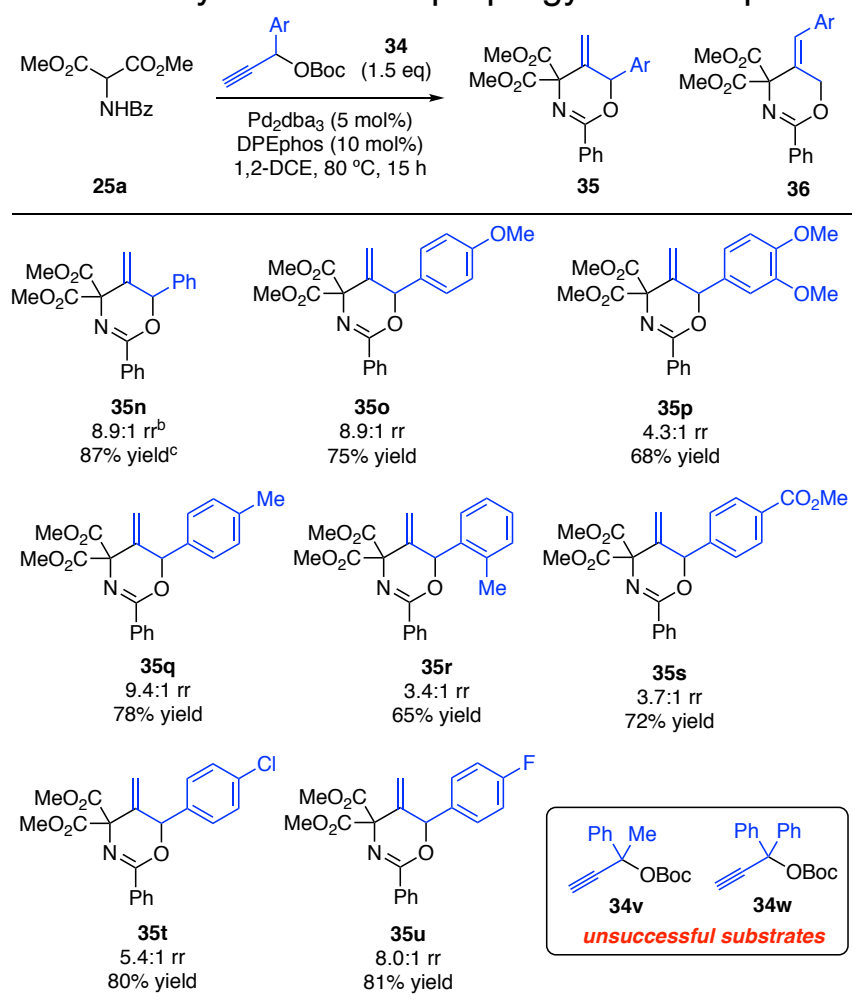

aReactions were performed on $0.2 \mathrm{mmol}$ scale.

${ }^{\mathrm{b}}$ Ratio of 35:36 determined by ${ }^{1} \mathrm{H}$ NMR spectroscopy of the crude product mixture.

cYield of isolated $\mathbf{3 5}$.

Although two individual sets of reaction conditions were required to maintain the efficiency and selectivity of the cyclisation of alkyl- and aryl-substituted propargylic electrophiles (Tables 4 and 6), we subsequently attempted the cyclisation of methyl-substituted propargyl carbonate 34a with benzamide 25a under the conditions used for reactions with arylsubstituted substrates (DPEphos, 1,2-DCE, $80^{\circ} \mathrm{C}$ ), and isolated heterocycle $35 \mathrm{a}$ in $92 \%$ yield (cf. Table 4, $88 \%$ yield of 35 a with Xantphos, $\mathrm{CH}_{2} \mathrm{Cl}_{2}, 60^{\circ} \mathrm{C}$ ). Given the equally high efficiency of this cyclisation, it is likely that DPEphos as the ligand and 1,2-DCE as the solvent under reflux may in fact represent more general reaction conditions for the efficient cyclisation of not only aryl- but also alkyl-substituted propargylic electrophiles. 


\section{Enantioselective cyclisation of $\alpha$-amido malonates}

The cyclisation of benzamide 25a with both alkyl- and aryl-substituted propargylic electrophiles has been shown to proceed with high levels of regioselectivity, in which allylic alkylation at the more substituted position is preferred, installing a chiral allylic centre. As such, these results present opportunities for the development of an enantioselective variant of the reaction using a chiral ligand for palladium provided that the desired regioselectivity is simultaneously maintained.

With this in mind, the cyclisation of bis-nucleophile 25a with methyl-substituted electrophile $34 a$ in the presence of a chiral ligand for palladium was explored (Table 7). Reactions using $(R)$-BINAP (L1), (R)-SEGPHOS (L2), ( $R$ )-P-PHOS (L3), and 2-furyl analogue of $(R)$-BIPHEP L4 as the chiral ligand in THF as the solvent all afforded 35a in good yield, with complete regioselectivity and no b-hydride elimination; however, the enantioselectivity was low (entries 1-4). The best result was obtained with ( $R$ )-Phanephos (L5) as the ligand (entry 5), giving 35a in $80 \%$ yield but low 38\% ee; the results using analogues of Phanephos, $\mathbf{L} 6$ and L7, were poorer (entries 6 and 7). Having previously observed the dramatic effect of the reaction solvent on the outcome of the cyclisation, a solvent screen was performed using ligand L5. Etherial solvents 1,4-dioxane and MTBE led to higher ees of up to 55\% (entries 8 and 9); however, the yields of 35 a were substantially lower. DME and 1,2-DCE as solvents maintained the enantioselectivity and the yields of 35a were high (entries 10 and 11). The best balance of reaction efficiency and selectivity was obtained in $\mathrm{CH}_{2} \mathrm{Cl}_{2}$, giving 35a in $90 \%$ yield and moderate $47 \%$ ee. 
Table 7. Optimisation of the enantioselective cyclisation. ${ }^{a}$

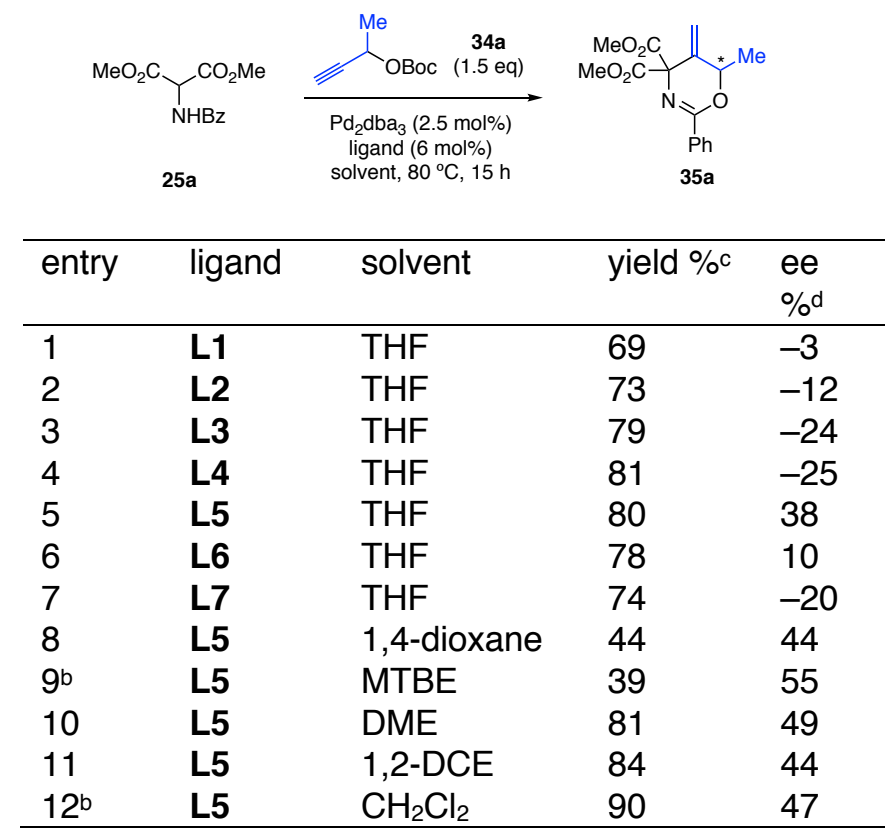

aReactions were performed on $0.15 \mathrm{mmol}$ scale. bReaction performed at $60^{\circ} \mathrm{C}$.

cYield of isolated 35a.

dDetermined by chiral HPLC.

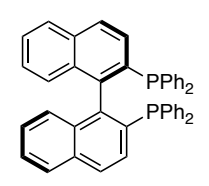

L1

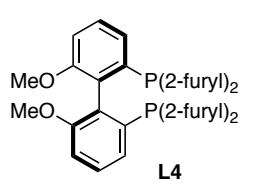

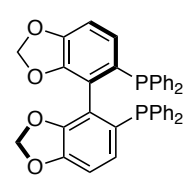

L2

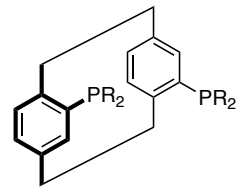

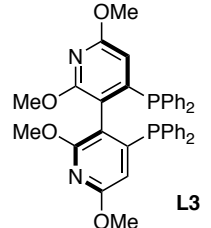

L5: $\mathrm{R}=\mathrm{Ph}$

L6: $R=3,5$-xylyl L7: $\mathrm{R}=p$-OMe-Ph

Although the enantioselectivity of cyclisation with methyl-substituted propargyl carbonate 34a was only moderate, we postulated that a substituent that is sterically larger than methyl may impart more significant steric bias in the transition state of allylic alkylation, potentially leading to higher levels of enantioselectivity. To test this idea, several alkyl- and arylsubstituted propargyl carbonates $\mathbf{3 4}$ were investigated in the enantioselective cyclisation with $\alpha$-amido malonate 25a using ( $R$ )-Phanephos (L5) as the chiral ligand for palladium under optimised reaction conditions (Table 8). Concerning the use of alkyl-substituted carbonates, all cyclisation reactions took place with complete regioselectivity at the more substituted position. Ethyl-substituted product $\mathbf{3 5 b}$ was isolated in near-quantitative yield with similar ee to 35a. Unfortunately, bulkier benzyl and isobutyl substituents led to essentially unselective reactions, albeit $\mathbf{3 5 d}$ and $\mathbf{3 5 f}$ were isolated in high yields. Piperidylsubstituted $35 \mathrm{~h}$ was also obtained with low ee. To our surprise, tert-butyl carbonate $\mathbf{3 4 k}$, which had been found too bulky to undergo cyclisation in racemic form, did give heterocycle $35 \mathrm{k}$ in $48 \%$ ee; however, the yield was very low. 
Table 8. Substrate scope of enantioselective cyclisation. ${ }^{a}$

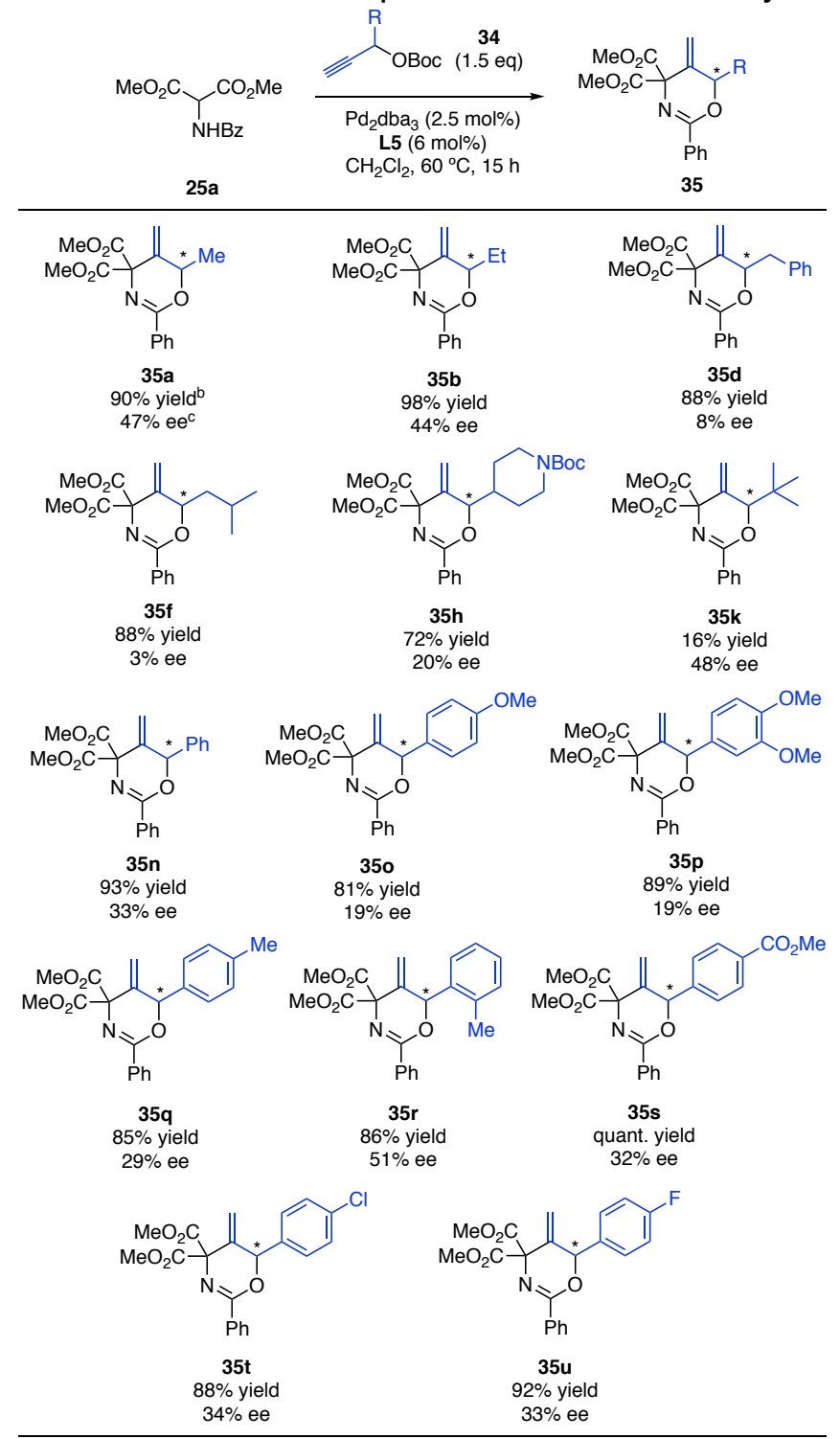

aReactions were performed on $0.15 \mathrm{mmol}$ scale.

bYield of isolated 35.

cDetermined by chiral HPLC.

Concerning aryl-substituted electrophiles 34, in contrast to the formation of products in racemic form (vide supra, Table 6), the cyclisation reactions in the presence of ligand L5 proceeded with complete regioselectivity ( $r r>19: 1)$ in all cases. As a result, the yields of products were consistently high. With respect to enantioselectivity, however, the ees were only moderate. In this context, phenyl-substituted 35 n was obtained with $33 \%$ ee, which decreased further with electron-donating substituents in 350 and $35 \mathrm{p}$. Although the ee of para-methyl-substituted $\mathbf{3 5 q}$ was only $29 \%$, ortho-methyl-substituted example $35 \mathrm{r}$ was isolated with the highest selectivity of $51 \%$ ee, presumably due to steric factors. Electronwithdrawing groups and halides in $35 \mathrm{~s}-\mathbf{u}$ gave ees of $32-34 \%$. 


\section{Reaction mechanism}

We postulate a reaction mechanism that is in accord with the general reactivity profile of propargylic electrophiles under palladium catalysis (Scheme 6). Oxidative addition of the palladium(0) catalyst to propargylic electrophile 34 results in the formation of $\pi-$ propargylpalladium(II) intermediate $\mathbf{3 8}$, releasing carbon dioxide gas and the tert-butoxide anion. Intermediate $\mathbf{3 8}$ can interconvert with its s-propargylpalladium(II) and sallenylpalladium(II) isomers. At this stage, bis-nucleophile 25a undergoes selective deprotonation by the hitherto expelled tert-butoxide anion to form an enolate nucleophile in situ due to a substantial difference in $\mathrm{p} K_{\mathrm{a}}$ between the malonate and the amide. The soft nature of the enolate ensures nucleophilic addition to the central carbon atom of $\pi-$ propargylpalladium(II) intermediate $\mathbf{3 8}$, giving rise to transient palladacyclobutene species 39.25 Protonation of palladacyclobutene 39 paves the way to the amide anion as the second nucleophile and the $\pi$-allylpalladium(II) electrophile in $\mathbf{4 0}$. In the final step, regioselective intramolecular allylic alkylation of the oxygen atom at the more substituted position of the $\pi-$ allylpalladium(II) cation affords dihydrooxazine heterocycle $\mathbf{3 5}$ and regenerates the palladium(0) catalyst.

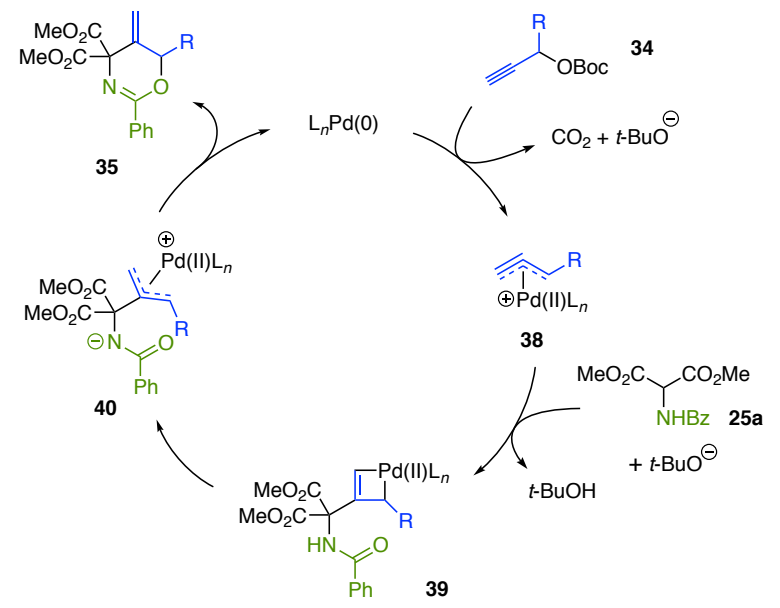

Scheme 6. Proposed reaction mechanism.

\section{Conclusions}

As part of the investigation into the palladium-catalysed cyclisation of $\alpha$-amino malonates with propargylic electrophiles, we have discovered $\alpha$-amido malonates as suitable bisnucleophiles for the catalytic construction of novel dihydrooxazine heterocycles in a manner that enables contemporaneous control of chemo-, regio- and, to some degree, stereoselectivity.

$\alpha$-Amido malonates were found to undergo cyclisation with complete chemoselectivity due to a substantial difference in $\mathrm{p} K_{\mathrm{a}}$ of the malonate and amide functionalities, whereby the presence of an amide $\mathrm{N}$-protecting group is essential to invoke the desired reactivity. A key observation was that the regioselective $O$-allylic alkylation, resulting in thermodynamic 6membered dihydrooxazine products, rather than the $\mathrm{N}$-allylic alkylation pathway to kinetic 4membered azetidine heterocycles, operates. The reaction tolerates a broad range of alkyland aryl-substituted allylic electrophiles, and affords functionalised dihydrooxazines with excellent levels of regioselectivity with respect to substitution at the $\pi$-allylpalladium(II) electrophile. Finally, although the levels of enantioselectivity were only moderate in our 
investigation of a stereoselective variant of the cyclisation, we have been able to simultaneously maintain full chemo- and regioselectivity.

As shown in this study, the synthesis of highly functionalised heterocycles by means of catalytic cyclisation of propargylic electrophiles is a challenging task due to the involvement of several layers of selectivity in a single process, as well as the sensitive nature of the reaction to both the structural features of the substrate and the reaction conditions, such as solvent and ligand. Nevertheless, upon careful optimisation, these challenges can be successfully overcome, offering access to new types of heterocycle with broad substitution in a single step. The development of an enantioselective cyclisation remains to be a formidable goal, exacerbated by the requirement for an elevated reaction temperature in order to achieve the desired reactivity.

\section{Experimental section.}

\section{General Experimental Section.}

All reactions were performed under an argon atmosphere in oven dry glassware. All commercially available starting materials were used as received without further purification. Solvents were of reagent grade and dried prior to use. Petrol refers to the fraction of petroleum ether that boils between $40^{\circ} \mathrm{C}$ and $60^{\circ} \mathrm{C}$. All aqueous reagents were saturated unless specified otherwise. Reactions were monitored by thin layer chromatography using pre-coated silica gel plates with a fluorescent indicator $(254 \mathrm{~nm})$ and visualized by UV light $(254 \mathrm{~nm})$ or by staining with potassium permanganate or aqueous acidic ammonium molybdate(IV) solutions. Flash column chromatography was carried out using Fisher silica gel (60 A particle size, 230-400 mesh). NMR spectra were recorded on either 400 or 300 $\mathrm{MHz}$ instruments ( ${ }^{1} \mathrm{H}$ NMR at 400 and $300 \mathrm{MHz}$, respectively, and ${ }^{13} \mathrm{C}$ NMR at 100 and 75 $\mathrm{MHz}$, respectively) in $\mathrm{CDCl}_{3}$. Residual solvent $\mathrm{CHCl}_{3}$ was referenced at $7.26 \mathrm{ppm}$ for ${ }^{1} \mathrm{H}$ NMR spectra and the central resonance of $\mathrm{CDCl}_{3}$ was referenced to $77.0 \mathrm{ppm}$ for ${ }^{13} \mathrm{C} \mathrm{NMR}$ spectra. IR spectra were recorded on an Agilent Technologies Cary 630 FTIR spectrometer as a neat film. High resolution mass spectrometry data were recorded using electron spray ionisation or atmospheric pressure chemical ionisation on an LCMS-IT-TOF mass spectrometer. Melting points were uncorrected. Chiral HPLC was performed on a Shimadzu instrument equipped with a UV detector. Optical rotation data were collected on an AA-65 automatic polarimeter. Single crystal X-ray crystallography data were collected on a SuperNova instrument.

\section{Experimental Procedures.}

The below compounds have been previously prepared and their characterisation data reported in the literature.

$\alpha$-Amido malonates: 23 and 25a; ${ }^{26} 24 ; 27$ 25i; 28 25l;,29 25m. ${ }^{30}$

Propargyl carbonates: $\mathbf{2 6}, \mathbf{3 4 l}$ and $\mathbf{3 4 n} ;{ }^{12} \mathbf{3 4 m} ;{ }^{31} \mathbf{3 4 0}, \mathbf{3 4 q}$ and $\mathbf{3 4 t} ;{ }^{32} \mathbf{3 4 r}$ and $\mathbf{3 4 u} ;{ }^{33} \mathbf{3 4 v}{ }^{34}$

Experimental procedures and analytical data for all novel compounds are provided below. 


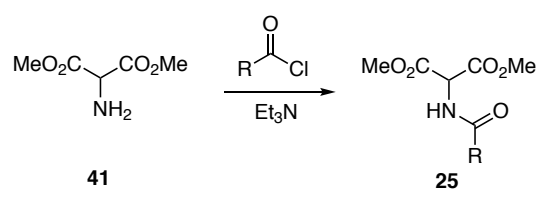

General Procedure A for the synthesis of $\alpha$-amido malonates 25. $\alpha$-Amino dimethylmalonate (41) was prepared via known literature methods. ${ }^{22}$ Amine 41 (290 mg, 2.0 mmol) was dissolved in $\mathrm{CH}_{2} \mathrm{Cl}_{2}(10 \mathrm{~mL})$. The requisite acid chloride $(2.0 \mathrm{mmol})$, followed by $\mathrm{Et}_{3} \mathrm{~N}(0.83 \mathrm{~mL}, 6.0 \mathrm{mmol})$ were added to the solution. The solution was stirred at room temperature overnight. The reaction was quenched with aq. $\mathrm{HCl}(1 \mathrm{~N}, 20 \mathrm{~mL})$. The organic phase was separated and the aqueous phase extracted with $\mathrm{CH}_{2} \mathrm{Cl}_{2}(2 \times 10 \mathrm{~mL})$. The combined organic phase was washed with brine $(20 \mathrm{~mL})$, dried $\left(\mathrm{MgSO}_{4}\right)$ and concentrated in vacuo. Purification by flash column chromatography afforded amide 25.

General Procedure B for cyclisation reactions of amides $\mathbf{2 5}$ with propargylic electrophile 26 to dihydrooxazines 33. A tube was charged with amide $25(0.20 \mathrm{mmol})$, propargylic electrophile 26 (50 mg, $0.30 \mathrm{mmol}), \mathrm{Pd}_{2} \mathrm{dba}_{3}(9.2 \mathrm{mg}, 0.010 \mathrm{mmol}$ ) and Xantphos (12 mg, $0.020 \mathrm{mmol})$. THF $(2 \mathrm{~mL})$ was added. The tube was sealed and the mixture heated at $80{ }^{\circ} \mathrm{C}$ for $1 \mathrm{~h}$. The solution was allowed to cool to room temperature and concentrated in vacuo. Purification by flash column chromatography afforded dihydrooxazine 33.

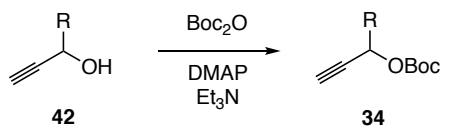

General Procedure $\mathbf{C}$ for the synthesis of substituted propargylic carbonates 34 . To a solution of di-tert-butyl dicarbonate (1-1.1 eq) in $\mathrm{CH}_{2} \mathrm{Cl}_{2}$ was added alcohol 42 (1 eq), followed by 4-dimethylaminopiridine (0.05-0.1 eq) and $\mathrm{Et}_{3} \mathrm{~N}$ (1.1-1.25 eq). The mixture was stirred at room temperature overnight. The reaction was quenched with aq. $\mathrm{HCl}(1 \mathrm{~N}, 30$ $\mathrm{mL})$. The organic phase was separated and the aqueous phase extracted with $\mathrm{CH}_{2} \mathrm{Cl}_{2}(2 \mathrm{x}$ $20 \mathrm{~mL})$. The combined organic phase was washed with brine $(50 \mathrm{~mL})$, dried $\left(\mathrm{MgSO}_{4}\right)$ and concentrated in vacuo. Purification by flash column chromatography afforded carbonate 34

General Procedure D for cyclisation reactions of amide 25a with alkyl-substituted propargylic carbonates 34 to dihydrooxazines 35 . A tube was charged with amide $25 \mathrm{a}$ (50 $\mathrm{mg}, 0.20 \mathrm{mmol})$, alkyl-substituted propargylic electrophile $34(0.30 \mathrm{mmol}), \mathrm{Pd}_{2} \mathrm{dba}_{3}(9.2 \mathrm{mg}$, $0.010 \mathrm{mmol}$ ) and Xantphos (12 mg, $0.020 \mathrm{mmol}) . \mathrm{CH}_{2} \mathrm{Cl}_{2}(2 \mathrm{~mL})$ was added. The tube was sealed and the mixture heated at $60^{\circ} \mathrm{C}$ for $15 \mathrm{~h}$. The solution was allowed to cool to room temperature and concentrated in vacuo. Purification by flash column chromatography afforded dihydrooxazine 35 .

General Procedure E for cyclisation reactions of amide 25a with aryl-substituted propargylic carbonates 34 to dihydrooxazines 35 . A tube was charged with amide 25 a $(50 \mathrm{mg}, 0.20$ $\mathrm{mmol})$, aryl-substituted propargylic electrophile 34 (0.30 mmol), $\mathrm{Pd}_{2} \mathrm{dba}_{3}(9.2 \mathrm{mg}, 0.010$ $\mathrm{mmol}$ ) and DPEphos (11 mg, $0.020 \mathrm{mmol}) .1,2-$ DCE $(2 \mathrm{~mL})$ was added. The tube was sealed and the mixture heated at $80^{\circ} \mathrm{C}$ for $15 \mathrm{~h}$. The solution was allowed to cool to room temperature and concentrated in vacuo. Purification by flash column chromatography afforded dihydrooxazine 35 .

General Procedure $\mathbf{F}$ for the enantioselective cyclisation reactions of amide 25a with propargylic carbonates 34 to dihydrooxazines 35 . A tube was charged with amide $25 a$ (38 
$\mathrm{mg}, 0.15 \mathrm{mmol})$, propargylic electrophile $34(0.23 \mathrm{mmol}), \mathrm{Pd}_{2} \mathrm{dba}_{3}(3.4 \mathrm{mg}, 0.0038 \mathrm{mmol})$ and $(R)$-Phanephos (5.2 mg, $0.0090 \mathrm{mmol}) . \mathrm{CH}_{2} \mathrm{Cl}_{2}(1.5 \mathrm{~mL})$ was added. The tube was sealed and the mixture heated at $60^{\circ} \mathrm{C}$ for $15 \mathrm{~h}$. The solution was allowed to cool to room temperature and concentrated in vacuo. Purification by flash column chromatography afforded dihydrooxazine 35 .

Dimethyl ((4-methylbenzoyl)amino)propanedioate (25b). Following General Procedure A, 41 was reacted with 4-methylbenzoyl chloride $(0.27 \mathrm{~mL})$. Purification by flash column chromatography [hexane:EtOAc $4: 1$ ] afforded $25 \mathrm{~b}(0.37 \mathrm{~g}, 70 \%)$ as a colourless solid. $R_{F}=$ 0.50 [petrol:EtOAc 1:1]. m.p. 123-125 ${ }^{\circ} \mathrm{C}$. IR (neat): 3319, 3032, 2959, 2940, $1742 \mathrm{~cm}^{-1} .{ }^{1} \mathrm{H}$ $\operatorname{NMR}\left(300 \mathrm{MHz}, \mathrm{CDCl}_{3}\right): \delta 7.73(\mathrm{~d}, J=8.3 \mathrm{~Hz}, 2 \mathrm{H}), 7.24(\mathrm{~d}, J=7.8 \mathrm{~Hz}, 2 \mathrm{H}), 7.13(\mathrm{~d}, J=7.0$ $\mathrm{Hz}, 1 \mathrm{H}), 5.39(\mathrm{~d}, J=6.9 \mathrm{~Hz}, 1 \mathrm{H}), 3.83(\mathrm{~s}, 6 \mathrm{H}), 2.39(\mathrm{~s}, 3 \mathrm{H}) .{ }^{13} \mathrm{C} \mathrm{NMR}\left(75 \mathrm{MHz}, \mathrm{CDCl}_{3}\right): \delta$ 166.9, 166.7, 142.7, 129.9, 129.2, 127.3, 56.4, 53.4, 21.4. HRMS (ESI) (m/z): calcd for $\mathrm{C}_{13} \mathrm{H}_{15} \mathrm{NO}_{5}[\mathrm{M}+\mathrm{Na}]^{+} 288.0842$; found 288.0830.

Dimethyl ((3-methylbenzoyl)amino)propanedioate (25c). Following General Procedure A, 41 was reacted with 3-methylbenzoyl chloride $(0.26 \mathrm{~mL})$. Purification by flash column chromatography [hexane:EtOAc $3: 1$ ] afforded $25 \mathrm{c}(0.28 \mathrm{~g}, 52 \%)$ as a colourless solid. $R_{F}=$ 0.48 [petrol:EtOAc 1:1]. m.p. 87-89 ${ }^{\circ} \mathrm{C}$. IR (neat): 3316, 3060, 1744, 1638, $1522 \mathrm{~cm}^{-1} .{ }^{1} \mathrm{H}$ $\operatorname{NMR}\left(400 \mathrm{MHz}, \mathrm{CDCl}_{3}\right)$ : $\delta$ 7.67-7.59 (m, 2H), 7.35-7.31 (m, 2H), $7.15(\mathrm{~d}, J=6.8 \mathrm{~Hz}, 1 \mathrm{H})$, $5.40(\mathrm{~d}, J=6.9 \mathrm{~Hz}, 1 \mathrm{H}), 3.84(\mathrm{~s}, 6 \mathrm{H}), 2.39(\mathrm{~s}, 3 \mathrm{H}) .{ }^{13} \mathrm{C} \mathrm{NMR}\left(100 \mathrm{MHz}, \mathrm{CDCl}_{3}\right): \delta$ 167.0, 166.8, 138.5, 132.9, 132.7, 128.5, 127.9, 124.3, 56.5, 53.5, 21.3. HRMS (ESI) $(\mathrm{m} / \mathrm{z}):$ calcd for $\mathrm{C}_{13} \mathrm{H}_{15} \mathrm{NO}_{5}[\mathrm{M}+\mathrm{H}]^{+}$266.1023; found 266.1010.

Dimethyl ((2-methylbenzoyl)amino)propanedioate (25d). Following General Procedure A, 41 was reacted with 2-methylbenzoyl chloride $(0.27 \mathrm{~mL})$. Purification by flash column chromatography [hexane:EtOAc $4: 1$ ] afforded $25 \mathrm{~d}(0.40 \mathrm{~g}, 75 \%)$ as a colourless solid. $R_{F}=$ 0.49 [petrol:EtOAc 1:1]. m.p. 86-88 ${ }^{\circ} \mathrm{C}$. IR (neat): 3276, 2963, 2924, 1757, $1744 \mathrm{~cm}^{-1} .{ }^{1} \mathrm{H}$ $\operatorname{NMR}\left(400 \mathrm{MHz}, \mathrm{CDCl}_{3}\right): \delta 7.48(\mathrm{~d}, J=7.9 \mathrm{~Hz}, 1 \mathrm{H}), 7.36(\mathrm{td}, J=7.3,1.5 \mathrm{~Hz}, 1 \mathrm{H}), 7.27-7.21$ $(\mathrm{m}, 2 \mathrm{H}), 6.78(\mathrm{~d}, J=6.2 \mathrm{~Hz}, 1 \mathrm{H}), 5.39(\mathrm{~d}, J=7.1 \mathrm{~Hz}, 1 \mathrm{H}), 3.86(\mathrm{~s}, 6 \mathrm{H}), 2.48(\mathrm{~s}, 3 \mathrm{H}) .{ }^{13} \mathrm{C}$ $\operatorname{NMR}\left(100 \mathrm{MHz}, \mathrm{CDCl}_{3}\right): \delta 166.4,166.7,136.8,134.5,131.2,130.6,127.1,125.8,56.4$, 53.5, 19.8. HRMS (ESI) $(\mathrm{m} / \mathrm{z})$ : calcd for $\mathrm{C}_{13} \mathrm{H}_{15} \mathrm{NO}_{5}[\mathrm{M}+\mathrm{Na}]^{+} 288.0842$; found 288.0836 .

Dimethyl ((2,4,6-trimethylbenzoyl)amino)propanedioate (25e). Following General Procedure A, 41 was reacted with 2,4,6-trimethylbenzoyl chloride $(0.33 \mathrm{~mL})$. Purification by flash column chromatography [hexane:EtOAc 3:1] afforded $25 \mathrm{e}(0.25 \mathrm{~g}, 42 \%)$ as a colourless solid. $R_{F}=0.59$ [petrol:EtOAc 1:1]. m.p. $90-93^{\circ} \mathrm{C}$. IR (neat): $3371,2956,1754$, 1655, $1506 \mathrm{~cm}^{-1}$. ${ }^{1} \mathrm{H}$ NMR $\left(400 \mathrm{MHz}, \mathrm{CDCl}_{3}\right): \delta 6.85(\mathrm{~d}, J=0.7 \mathrm{~Hz}, 2 \mathrm{H}), 6.68(\mathrm{~d}, J=7.0 \mathrm{~Hz}$, $1 \mathrm{H}), 5.41(\mathrm{~d}, J=7.0 \mathrm{~Hz}, 1 \mathrm{H}), 3.85(\mathrm{~s}, 6 \mathrm{H}), 2.30(\mathrm{~s}, 6 \mathrm{H}), 2.28(\mathrm{~s}, 3 \mathrm{H}) .{ }^{13} \mathrm{C} \mathrm{NMR}(100 \mathrm{MHz}$, $\left.\mathrm{CDCl}_{3}\right): \delta 170.1,166.5,139.0,134.6,133.2,128.2,56.0,53.4,21.1,19.0$. HRMS (ESI) $(\mathrm{m} / \mathrm{z})$ : calcd for $\mathrm{C}_{15} \mathrm{H}_{19} \mathrm{NO}_{5}[\mathrm{M}+\mathrm{Na}]^{+} 316.1155$; found 316.1150 .

Dimethyl ((4-methoxybenzoyl)amino)propanedioate (25f). Following General Procedure A, 41 was reacted with $p$-methoxybenzoyl chloride $(0.34 \mathrm{~g})$. Purification by flash column chromatography [hexane:EtOAc $4: 1$ ] afforded $25 \mathrm{f}(0.47 \mathrm{~g}, 84 \%)$ as a colourless solid. $R_{F}=$ 0.50 [petrol:EtOAc 1:1]. m.p. $116-119^{\circ} \mathrm{C}$. IR (neat): 3324, 2961, 2939, 2841, $1742 \mathrm{~cm}^{-1} .{ }^{1} \mathrm{H}$ $\operatorname{NMR}\left(400 \mathrm{MHz}, \mathrm{CDCl}_{3}\right): \delta 7.81(\mathrm{~d}, J=8.9 \mathrm{~Hz}, 2 \mathrm{H}), 7.05(\mathrm{~d}, J=6.7 \mathrm{~Hz}, 1 \mathrm{H}), 6.93(\mathrm{~d}, J=8.9$ $\mathrm{Hz}, 2 \mathrm{H}), 5.38(\mathrm{~d}, J=6.8 \mathrm{~Hz}, 1 \mathrm{H}), 3.85(\mathrm{~s}, 3 \mathrm{H}), 3.84(\mathrm{~s}, 6 \mathrm{H}) \cdot{ }^{13} \mathrm{C} \mathrm{NMR}\left(100 \mathrm{MHz}, \mathrm{CDCl}_{3}\right): \delta$ 167.0, 166.3, 162.7, 129.2, 125.1, 113.8, 56.5, 55.4, 53.5. HRMS (APCl) $(\mathrm{m} / \mathrm{z})$ : calcd for $\mathrm{C}_{13} \mathrm{H}_{15} \mathrm{NO}_{6}[\mathrm{M}+\mathrm{H}]+282.0972$; found 282.0965 . 
Dimethyl ((4-nitrobenzoyl)amino)propanedioate (25g). Following General Procedure A, 41 was reacted with $p$-nitrobenzoyl chloride $(0.37 \mathrm{~g})$. Purification by flash column chromatography [hexane:EtOAc $9: 1$ ] afforded $\mathbf{2 5 g}(0.24 \mathrm{~g}, 42 \%)$ as a colourless solid. $R_{F}=$ 0.63 [petrol:EtOAc 3:1]. m.p. 150-153 ${ }^{\circ} \mathrm{C}$. IR (neat): 3324, 2961, 2939, 2841, $1742 \mathrm{~cm}^{-1} .{ }^{1} \mathrm{H}$ $\operatorname{NMR}\left(400 \mathrm{MHz}, \mathrm{CDCl}_{3}\right): \delta 8.32(\mathrm{~d}, J=9.0 \mathrm{~Hz}, 2 \mathrm{H}), 8.02(\mathrm{~d}, J=9.0 \mathrm{~Hz}, 2 \mathrm{H}), 7.22(\mathrm{~d}, J=6.5$ $\mathrm{Hz}, 1 \mathrm{H}), 5.38(\mathrm{~d}, J=6.8 \mathrm{~Hz}, 1 \mathrm{H}), 3.88(\mathrm{~s}, 6 \mathrm{H}) .{ }^{13} \mathrm{C} \mathrm{NMR}\left(100 \mathrm{MHz}, \mathrm{CDCl}_{3}\right): \delta 166.4,164.9$, 150.0, 138.3, 128.6, 123.9, 56.6, 53.8. HRMS (APCI) $(\mathrm{m} / \mathrm{z})$ : calcd for $\mathrm{C}_{12} \mathrm{H}_{12} \mathrm{~N}_{2} \mathrm{O}_{7}[\mathrm{M}+\mathrm{H}]^{+}$ 297.0717; found 297.0729.

Dimethyl ((4-fluorobenzoyl)amino)propanedioate (25h). Following General Procedure A, 41 was reacted with 4 -fluorobenzoyl chloride $(0.26 \mathrm{~mL})$. Purification by flash column chromatography [hexane:EtOAc $4: 1$ ] afforded $25 \mathrm{~h}(0.42 \mathrm{~g}, 77 \%)$ as a colourless solid. $R_{F}=$ 0.55 [petrol:EtOAc 1:1]. m.p. 101-106 ${ }^{\circ} \mathrm{C}$. IR (neat): 3334, 2961, 2937, 1759, $1744 \mathrm{~cm}^{-1} .{ }^{1} \mathrm{H}$ $\operatorname{NMR}\left(300 \mathrm{MHz}, \mathrm{CDCl}_{3}\right): \delta 7.82(\mathrm{dd}, J=8.9,5.2 \mathrm{~Hz}, 2 \mathrm{H}), 7.05(\mathrm{t}, J=8.8 \mathrm{~Hz}, 2 \mathrm{H}), 5.35(\mathrm{~d}, J$ $=7.0 \mathrm{~Hz}, 1 \mathrm{H}), 3.77(\mathrm{~s}, 6 \mathrm{H}) .{ }^{13} \mathrm{C} \mathrm{NMR}\left(75 \mathrm{MHz}, \mathrm{CDCl}_{3}\right): \delta 166.6,165.7,164.9(\mathrm{~d}, J=252.6$ $\mathrm{Hz}), 129.7(\mathrm{~d}, J=9.0 \mathrm{~Hz}), 128.9(\mathrm{~d}, J=3.2 \mathrm{~Hz}), 115.5(\mathrm{~d}, J=22.0 \mathrm{~Hz}), 56.3,53.3$. HRMS (ESI) $(\mathrm{m} / \mathrm{z})$ : calcd for $\mathrm{C}_{12} \mathrm{H}_{12} \mathrm{NO}_{5} \mathrm{~F}[\mathrm{M}+\mathrm{Na}]^{+}$292.0592; found 292.0593 .

Dimethyl ((4-bromobenzoyl)amino)propanedioate (25j). Following General Procedure A, 41 was reacted with 4-bromobenzoyl chloride $(0.44 \mathrm{~g})$. Purification by flash column chromatography [hexane:EtOAc 9:1] afforded $25 \mathrm{j}(0.51 \mathrm{~g}, 77 \%)$ as a colourless solid. $R_{F}=$ 0.66 [petrol:EtOAc 1:1]. m.p. $161-163^{\circ} \mathrm{C}$. IR (neat): 3313, 2957, 2939, 1759, $1744 \mathrm{~cm}^{-1} .{ }^{1} \mathrm{H}$ $\operatorname{NMR}\left(400 \mathrm{MHz}, \mathrm{CDCl}_{3}\right): \delta 7.71(\mathrm{~d}, J=8.8 \mathrm{~Hz}, 2 \mathrm{H}), 7.60(\mathrm{~d}, J=8.8 \mathrm{~Hz}, 2 \mathrm{H}), 7.10(\mathrm{~d}, J=7.2$ $\mathrm{Hz}, 1 \mathrm{H}), 5.37(\mathrm{~d}, J=6.8 \mathrm{~Hz}, 1 \mathrm{H}), 3.86(\mathrm{~s}, 6 \mathrm{H}) .{ }^{13} \mathrm{C} \mathrm{NMR}\left(100 \mathrm{MHz}, \mathrm{CDCl}_{3}\right): \delta 166.7,165.9$, 131.9, 131.7, 128.9, 127.1, 56.5, 53.6. HRMS (APCl) $(\mathrm{m} / \mathrm{z})$ : calcd for $\mathrm{C}_{12} \mathrm{H}_{12}{ }^{79} \mathrm{BrNO}_{5}[\mathrm{M}+\mathrm{H}]^{+}$ 329.9972; found 329.9962 .

Dimethyl ((furan-2-ylcarbonyl)amino)propanedioate (25k). Following General Procedure A, 41 was reacted with furan-2-acetyl chloride $(0.21 \mathrm{~mL})$. Purification by flash column chromatography [hexane:EtOAc $5: 1$ ] afforded $25 \mathbf{k}(0.24 \mathrm{~g}, 49 \%)$ as a colourless solid. $R_{F}=$ 0.51 [petrol:EtOAc 1:1]. m.p. $130-137^{\circ} \mathrm{C}$. IR (neat): 3386, 3114, 2995, 1756, $1734 \mathrm{~cm}^{-1} .{ }^{1} \mathrm{H}$ $\operatorname{NMR}\left(400 \mathrm{MHz}, \mathrm{CDCl}_{3}\right): \delta 7.50(\mathrm{dd}, J=1.8,0.9 \mathrm{~Hz}, 1 \mathrm{H}), 7.28(\mathrm{~d}, J=7.0 \mathrm{~Hz}, 1 \mathrm{H}), 7.17$ (dd, $J=3.5,0.9 \mathrm{~Hz}, 1 \mathrm{H}), 6.52(\mathrm{dd}, J=3.5,1.7 \mathrm{~Hz}, 1 \mathrm{H}), 5.37(\mathrm{~d}, J=7.2 \mathrm{~Hz}, 1 \mathrm{H}), 3.85(\mathrm{~s}, 6 \mathrm{H}) .{ }^{13} \mathrm{C}$ $\operatorname{NMR}\left(100 \mathrm{MHz}, \mathrm{CDCl}_{3}\right): \delta 166.6,157.6,146.8,144.6,115.5,112.3,55.7,53.6$. HRMS (APCl) $(\mathrm{m} / \mathrm{z})$ : calcd for $\mathrm{C}_{10} \mathrm{H}_{11} \mathrm{NO}_{6}[\mathrm{M}+\mathrm{H}]^{+} 242.0659$; found 242.0655 .

Tetramethyl 2,2,13,13-tetramethyl-7-methylidene-4,11-dioxo-3,12-dioxa-5,10diazatetradecane-6,6,9,9-tetracarboxylate (30). A tube was charged with carbamate 24 (49 mg, $0.20 \mathrm{mmol}$ ), propargylic electrophile 26 (47 mg, $0.30 \mathrm{mmol}), \mathrm{Pd}_{2} \mathrm{dba}_{3}(9.2 \mathrm{mg}, 0.010$ $\mathrm{mmol}$ ) and DPEphos (11 mg, $0.020 \mathrm{mmol})$. THF $(2 \mathrm{~mL})$ was added. The tube was sealed and the mixture heated at $80^{\circ} \mathrm{C}$ for $15 \mathrm{~h}$. The solution was allowed to cool to room temperature and concentrated in vacuo. Purification by flash column chromatography [hexane:EtOAc 4:1-2:1] afforded homocoupled product $30(43 \mathrm{mg}, 81 \%)$ as a yellow oil. $R_{F}=$ 0.53 [petrol:EtOAc 1:1]. IR (neat): 3425, 2956, 1743, $1715 \mathrm{~cm}^{-1} .{ }^{1} \mathrm{H}$ NMR $\left(300 \mathrm{MHz}, \mathrm{CDCl}_{3}\right)$ : ס $5.91(\mathrm{br} \mathrm{s}, 2 \mathrm{H}), 5.57(\mathrm{~s}, 1 \mathrm{H}), 5.34(\mathrm{~s}, 1 \mathrm{H}), 3.77(\mathrm{~s}, 6 \mathrm{H}), 3.73(\mathrm{~s}, 6 \mathrm{H}), 3.27(\mathrm{~s}, 2 \mathrm{H}), 1.42(\mathrm{~s}$, 18H). ${ }^{13} \mathrm{C}$ NMR $\left(75 \mathrm{MHz}, \mathrm{CDCl}_{3}\right): \delta 168.4,167.4,154.2,137.0,120.0,80.6,80.4,70.1,66.3$, 53.5, 53.4, 34.7, 28.2, 28.1. HRMS (ESI) $(\mathrm{m} / \mathrm{z})$ : calcd for $\mathrm{C}_{23} \mathrm{H}_{36} \mathrm{~N}_{2} \mathrm{O}_{12}[\mathrm{M}+\mathrm{Na}]^{+} 555.2160$; found 555.2146 .

Tetramethyl 1,4-bis(benzoylamino)-2-methylidenebutane-1,1,4,4-tetracarboxylate (32). A tube was charged with amide $25 \mathrm{a}(50.2 \mathrm{mg}, 0.2 \mathrm{mmol})$, propargylic electrophile 26 (47 $\mathrm{mg}$, $0.30 \mathrm{mmol}), \mathrm{Pd}_{2} \mathrm{dba}_{3}(9.2 \mathrm{mg}, 0.010 \mathrm{mmol})$ and $\mathrm{dppf}(11 \mathrm{mg}, 0.020 \mathrm{mmol})$. THF (2 mL) was 
added. The mixture was stirred at room temperature for $15 \mathrm{~h}$, then concentrated in vacuo. Purification by flash column chromatography [hexane:EtOAc 1:1] afforded homocoupled product 32 (53 mg, 98\%) as a sticky yellow oil. $R_{F}=0.22$ [petrol:EtOAc 1:1]. IR (neat): 3411 , 2956, 1737, 1664, $1508 \mathrm{~cm}^{-1}$. ${ }^{1} \mathrm{H}$ NMR $\left(400 \mathrm{MHz}, \mathrm{CDCl}_{3}\right): \delta 7.74(\mathrm{~d}, J=7.0 \mathrm{~Hz}, 4 \mathrm{H}), 7.57$ (s, 1H), 7.54-7.45 (m, 3H), 7.44-7.34 (m, 4H), $5.72(\mathrm{~s}, 1 \mathrm{H}), 5.39(\mathrm{~s}, 1 \mathrm{H}), 3.77(\mathrm{~s}, 6 \mathrm{H}), 3.75$ (s, 6H), $3.52(\mathrm{~d}, J=1.1 \mathrm{~Hz}, 2 \mathrm{H}) .{ }^{13} \mathrm{C} \mathrm{NMR}\left(100 \mathrm{MHz}, \mathrm{CDCl}_{3}\right): \delta$ 168.4, 167.3, 166.2, 166.0, 136.6, 132.9, 132.8, 132.0, 131.9, 128.5, 128.5, 127.2, 120.8, 69.8, 66.5, 53.8, 53.7, 34.8. HRMS (ESI) $(\mathrm{m} / \mathrm{z})$ : calcd for $\mathrm{C}_{27} \mathrm{H}_{28} \mathrm{~N}_{2} \mathrm{O}_{10}[\mathrm{M}-\mathrm{H}]^{-} 539.1671$; found 539.1667.

Dimethyl 5-methylidene-2-phenyl-5,6-dihydro-4H-1,3-oxazine-4,4-dicarboxylate (33a). Following General Procedure B, amide 25a $(50 \mathrm{mg}, 0.20 \mathrm{mmol})$ underwent the palladiumcatalysed cyclisation. Purification by flash column chromatography [hexane:EtOAc 4:1] afforded 33a (38 mg, 66\%) as a brown solid.

The analogous reaction was carried out on larger scale. To a solution of amide $25 \mathrm{a}(2.51 \mathrm{~g}$, $10.0 \mathrm{mmol})$ in THF $(100 \mathrm{~mL})$ was added $\mathrm{Pd}_{2} \mathrm{dba}_{3}(0.46 \mathrm{~g}, 0.50 \mathrm{mmol})$ and Xantphos $(0.58 \mathrm{~g}$, $1.0 \mathrm{mmol})$. The mixture was heated to $80^{\circ} \mathrm{C}$ under reflux for $30 \mathrm{~min}$. A solution of propargylic electrophile $26(2.34 \mathrm{~g}, 15.0 \mathrm{mmol})$ in THF $(5 \mathrm{~mL})$ was added dropwise via syringe. The mixture was heated at $80^{\circ} \mathrm{C}$ under reflux for $15 \mathrm{~h}$. The mixture was allowed to cool to room temperature and filtered through celite. Water $(300 \mathrm{~mL})$ was added and the mixture extracted with EtOAc $(2 \times 250 \mathrm{~mL})$. The combined organic phase was washed with half-saturated brine $(500 \mathrm{~mL})$, dried $\left(\mathrm{MgSO}_{4}\right)$ and concentrated in vacuo. Purification by flash column chromatography [hexane:EtOAc 9:1-4:1] afforded 33a (1.82 g, 63\%) as a brown solid.

$R_{F}=0.53$ [petrol:EtOAc 1:1]. m.p. $141-143^{\circ} \mathrm{C}$. IR (neat): 3006, 2895, 1738, $1634 \mathrm{~cm}^{-1} .{ }^{1} \mathrm{H}$ $\operatorname{NMR}\left(400 \mathrm{MHz}, \mathrm{CDCl}_{3}\right): \delta 8.01(\mathrm{~d}, J=8.6 \mathrm{~Hz}, 2 \mathrm{H}), 7.46(\mathrm{tt}, J=7.3,1.4 \mathrm{~Hz}, 1 \mathrm{H}), 7.38(\mathrm{t}, J=$ $7.7 \mathrm{~Hz}, 2 \mathrm{H}), 5.47(\mathrm{t}, J=1.1 \mathrm{~Hz}, 1 \mathrm{H}), 5.36(\mathrm{~s}, 1 \mathrm{H}), 4.81(\mathrm{~s}, 2 \mathrm{H}), 3.85(\mathrm{~s}, 6 \mathrm{H}) .{ }^{13} \mathrm{C}$ NMR $(100$ $\left.\mathrm{MHz}, \mathrm{CDCl}_{3}\right): \delta 168.6,157.5,134.3,132.6,131.3,128.0,128.0,115.9,70.0,68.1,53.3$. HRMS (ESI) $(\mathrm{m} / \mathrm{z})$ : calcd for $\mathrm{C}_{15} \mathrm{H}_{15} \mathrm{NO}_{5}[\mathrm{M}+\mathrm{H}]^{+} 290.1023$; found 290.1021.

Dimethyl 5-methylidene-2-(4-methylphenyl)-5,6-dihydro-4H-1,3-oxazine-4,4dicarboxylate (33b). Following General Procedure B, amide 25b (53 mg, $0.20 \mathrm{mmol})$ underwent the palladium-catalysed cyclisation. Purification by flash column chromatography [hexane:EtOAc 6:1] afforded $33 \mathrm{~b}$ (33 $\mathrm{mg}, 55 \%)$ as a colourless solid. $R_{F}=0.40$ [petrol:EtOAc 2:1]. m.p. $120-124{ }^{\circ} \mathrm{C}$. IR (neat): $3032,2953,1738,1643 \mathrm{~cm}^{-1}$. ${ }^{1} \mathrm{H}$ NMR $(400$ $\left.\mathrm{MHz}, \mathrm{CDCl}_{3}\right): \delta 7.88(\mathrm{~d}, J=8.1 \mathrm{~Hz}, 2 \mathrm{H}), 7.18(\mathrm{~d}, J=7.9 \mathrm{~Hz}, 2 \mathrm{H}), 5.45(\mathrm{t}, J=1.2 \mathrm{~Hz}, 1 \mathrm{H})$, $5.35(\mathrm{~s}, 1 \mathrm{H}), 4.79(\mathrm{~d}, J=0.6 \mathrm{~Hz}, 2 \mathrm{H}), 3.84(\mathrm{~s}, 6 \mathrm{H}), 2.37(\mathrm{~s}, 3 \mathrm{H}) .{ }^{13} \mathrm{C} \mathrm{NMR}\left(100 \mathrm{MHz}, \mathrm{CDCl}_{3}\right)$ : $\delta 168.7,157.6,141.6,134.5,129.9,128.8,127.9,115.7,70.0,68.0,53.3,21.5$. HRMS (ESI) $(\mathrm{m} / \mathrm{z})$ : calcd for $\mathrm{C}_{16} \mathrm{H}_{17} \mathrm{NO}_{5}[\mathrm{M}+\mathrm{Na}]+326.0999$; found 326.1002.

Dimethyl 5-methylidene-2-(3-methylphenyl)-5,6-dihydro-4H-1,3-oxazine-4,4dicarboxylate (33c). Following General Procedure B, amide 25c (53 mg, $0.20 \mathrm{mmol})$ underwent the palladium-catalysed cyclisation. Purification by flash column chromatography [hexane:EtOAc 6:1] afforded $33 \mathrm{c}(34.5 \mathrm{mg}, 57 \%)$ as a pale yellow oil. $R_{F}=0.52$ [petrol:EtOAc 2:1]. IR (neat): 2953, 1735, $1640 \mathrm{~cm}^{-1}$. ${ }^{1} \mathrm{H}$ NMR $\left(400 \mathrm{MHz}, \mathrm{CDCl}_{3}\right): \delta 7.85-$ $7.82(\mathrm{~m}, 1 \mathrm{H}), 7.79-7.73(\mathrm{~m}, 1 \mathrm{H}), 7.28-7.24(\mathrm{~m}, 2 \mathrm{H}), 5.46(\mathrm{t}, J=1.2 \mathrm{~Hz}, 1 \mathrm{H}), 5.35(\mathrm{~s}, 1 \mathrm{H})$, $4.80(\mathrm{~d}, J=0.7 \mathrm{~Hz}, 2 \mathrm{H}), 3.84(\mathrm{~s}, 6 \mathrm{H}), 2.37(\mathrm{~s}, 3 \mathrm{H}) .{ }^{13} \mathrm{C} \mathrm{NMR}\left(100 \mathrm{MHz}, \mathrm{CDCl}_{3}\right): \delta 168.6$, 157.6, 137.8, 134.3, 132.5, 132.1, 128.5, 127.9, 125.0, 115.8, 70.0, 68.0, 53.3, 21.2. HRMS (ESI) $(\mathrm{m} / \mathrm{z})$ : calcd for $\mathrm{C}_{16} \mathrm{H}_{17} \mathrm{NO}_{5}[\mathrm{M}+\mathrm{Na}]^{+} 326.0999$; found 326.0993 . 
Dimethyl 5-methylidene-2-(2-methylphenyl)-5,6-dihydro-4H-1,3-oxazine-4,4-

dicarboxylate (33d). Following General Procedure B, amide 25d (53 mg, $0.20 \mathrm{mmol})$ underwent the palladium-catalysed cyclisation. Purification by flash column chromatography [hexane:EtOAc 6:1] afforded $33 \mathrm{~d}(39.5 \mathrm{mg}, 65 \%)$ as a colourless solid. $R_{F}=0.43$ [petrol:EtOAc 2:1]. m.p. $128-130^{\circ} \mathrm{C}$. IR (neat): 2953, 1736, $1645 \mathrm{~cm}^{-1}$. ${ }^{1} \mathrm{H}$ NMR $(400 \mathrm{MHz}$, $\left.\mathrm{CDCl}_{3}\right): \delta 7.61-7.57(\mathrm{~m}, 1 \mathrm{H}), 7.29(\mathrm{td}, J=7.4,1.5 \mathrm{~Hz}, 1 \mathrm{H}), 7.19(\mathrm{t}, J=7.0 \mathrm{~Hz}, 2 \mathrm{H}), 5.48(\mathrm{t}, J$ $=1.2 \mathrm{~Hz}, 1 \mathrm{H}), 5.39(\mathrm{~s}, 1 \mathrm{H}), 4.79(\mathrm{~d}, J=0.6 \mathrm{~Hz}, 2 \mathrm{H}), 3.85(\mathrm{~s}, 6 \mathrm{H}), 2.48(\mathrm{~s}, 3 \mathrm{H}) .{ }^{13} \mathrm{C}$ NMR $(100$ $\left.\mathrm{MHz}, \mathrm{CDCl}_{3}\right): \delta 168.5,159.8,137.6,134.2,132.9,130.9,130.1,129.3,125.5,115.9,70.0$, 68.0, 53.3, 20.5. HRMS (ESI) $(\mathrm{m} / \mathrm{z})$ : calcd for $\mathrm{C}_{16} \mathrm{H}_{17} \mathrm{NO}_{5}[\mathrm{M}+\mathrm{H}]^{+} 304.1179$; found 304.1164.

\section{Dimethyl 5-methylidene-2-(2,4,6-trimethylphenyl)-5,6-dihydro-4H-1,3-oxazine-4,4- dicarboxylate (33e). Following General Procedure B, amide 25e (59 mg, $0.20 \mathrm{mmol}$ )} underwent the palladium-catalysed cyclisation. Purification by flash column chromatography [hexane:EtOAc 6:1] afforded $33 \mathrm{e}(31 \mathrm{mg}, 47 \%)$ as a clear oil. $R_{F}=0.62$ [petrol:EtOAc 2:1]. IR (neat): 2954, 2920, 1735, $1655 \mathrm{~cm}^{-1}$. ${ }^{1} \mathrm{H}$ NMR $\left(400 \mathrm{MHz}, \mathrm{CDCl}_{3}\right): \delta 6.81$ (d, $J=0.7 \mathrm{~Hz}$, $2 \mathrm{H}), 5.49(\mathrm{t}, J=1.2 \mathrm{~Hz}, 1 \mathrm{H}), 5.40(\mathrm{~s}, 1 \mathrm{H}), 4.77(\mathrm{~d}, J=0.6 \mathrm{~Hz}, 2 \mathrm{H}), 3.83(\mathrm{~s}, 6 \mathrm{H}), 2.26(\mathrm{~s}, 6 \mathrm{H})$, $2.24(\mathrm{~s}, 3 \mathrm{H}) .{ }^{13} \mathrm{C} \mathrm{NMR}\left(100 \mathrm{MHz}, \mathrm{CDCl}_{3}\right): \delta 168.4,160.1,138.7,135.7,133.8,130.9,128.0$, 116.1, 69.8, 68.0, 53.2, 21.1, 18.9. HRMS (ESI) $(\mathrm{m} / \mathrm{z})$ : calcd for $\mathrm{C}_{18} \mathrm{H}_{21} \mathrm{NO}_{5}[\mathrm{M}+\mathrm{Na}]^{+}$ 354.1312; found 354.1304.

\section{Dimethyl 2-(4-methoxyphenyl)-5-methylidene-5,6-dihydro-4H-1,3-oxazine-4,4- dicarboxylate (33f). Following General Procedure B, amide $25 f(56 \mathrm{mg}, 0.2 \mathrm{mmol}$ )} underwent the palladium-catalysed cyclisation. Purification by flash column chromatography [hexane:EtOAc 3:1] afforded $33 \mathrm{f}$ (39 $\mathrm{mg}, 61 \%)$ as a brown solid. $R_{F}=0.41$ [petrol:EtOAc 2:1]. m.p. $114-117^{\circ} \mathrm{C}$. IR (neat): $2950,2845,1735,1638 \mathrm{~cm}^{-1}$. ${ }^{1} \mathrm{H} \mathrm{NMR}\left(400 \mathrm{MHz}, \mathrm{CDCl}_{3}\right)$ : $\delta 7.95(\mathrm{~d}, J=8.9 \mathrm{~Hz}, 2 \mathrm{H}), 6.87(\mathrm{~d}, J=8.9 \mathrm{~Hz}, 2 \mathrm{H}), 5.45(\mathrm{~s}, 1 \mathrm{H}), 5.34(\mathrm{~s}, 1 \mathrm{H}), 4.78(\mathrm{~s}, 2 \mathrm{H})$, $3.84(\mathrm{~s}, 6 \mathrm{H}), 3.83(\mathrm{~s}, 3 \mathrm{H}) .{ }^{13} \mathrm{C}$ NMR $\left(100 \mathrm{MHz} \mathrm{CDCl}_{3}\right): \delta 168.7,162.2,157.4,134.5,129.8$, $125.1,115.7,113.4,70.0,68.0,55.4,53.3$. HRMS (ESI) $(\mathrm{m} / \mathrm{z})$ : calcd for $\mathrm{C}_{16} \mathrm{H}_{17} \mathrm{NO}_{6}[\mathrm{M}+\mathrm{H}]^{+}$ 320.1129 ; found 320.1122 .

\section{Dimethyl 5-methylidene-2-(4-nitrophenyl)-5,6-dihydro-4H-1,3-oxazine-4,4- dicarboxylate (33g). Following General Procedure B, amide $\mathbf{2 5 g}(59 \mathrm{mg}, 0.2 \mathrm{mmol})$ underwent the palladium-catalysed cyclisation. Purification by flash column chromatography [hexane:EtOAc 5:1] afforded $\mathbf{3 3 g}$ (33 $\mathrm{mg}, 49 \%)$ as a brown solid. $R_{F}=0.51$ [petrol:EtOAc 2:1]. m.p. $113-116^{\circ} \mathrm{C}$. IR (neat): $2957,2853,1733,1641 \mathrm{~cm}^{-1}$. ${ }^{1} \mathrm{H} \mathrm{NMR}\left(400 \mathrm{MHz}, \mathrm{CDCl}_{3}\right)$ : $\delta 8.23(\mathrm{~d}, J=9.0 \mathrm{~Hz}, 2 \mathrm{H}), 8.18(\mathrm{~d}, J=9.1 \mathrm{~Hz}, 2 \mathrm{H}), 5.51(\mathrm{~s}, 1 \mathrm{H}), 5.40(\mathrm{~s}, 1 \mathrm{H}), 4.86(\mathrm{~s}, 2 \mathrm{H})$, $3.86(\mathrm{~s}, 6 \mathrm{H}) .{ }^{13} \mathrm{C}$ NMR $\left(75 \mathrm{MHz}, \mathrm{CDCl}_{3}\right): \delta 168.1,155.5,149.6,138.3,133.4,129.0,123.2$, 116.7, 70.0, 68.4, 53.4. HRMS (ESI) $(\mathrm{m} / \mathrm{z})$ : calcd for $\mathrm{C}_{15} \mathrm{H}_{14} \mathrm{~N}_{2} \mathrm{O}_{7}[\mathrm{M}+\mathrm{H}]+335.0874$; found 335.0875 .}

Dimethyl 2-(4-fluorophenyl)-5-methylidene-5,6-dihydro-4H-1,3-oxazine-4,4dicarboxylate (33h). Following General Procedure B, amide $25 \mathrm{~h}(54 \mathrm{mg}, 0.2 \mathrm{mmol}$ ) underwent the palladium-catalysed cyclisation. Purification by flash column chromatography [hexane:EtOAc 9:1] afforded $33 \mathrm{~h}(23 \mathrm{mg}, 37 \%)$ as a colourless solid. $R_{F}=0.45$ [petrol:EtOAc 2:1]. m.p. $151-153^{\circ} \mathrm{C}$. IR (neat): $2957,2888,1737,1645 \mathrm{~cm}^{-1} .{ }^{1} \mathrm{H}$ NMR $(400$ $\mathrm{MHz}, \mathrm{CDCl}_{3}$ ): $\delta 8.00$ (dd, $J=9.0,5.5 \mathrm{~Hz}, 2 \mathrm{H}$ ), 7.05 (dd, $J=9.1,8.5 \mathrm{~Hz}, 2 \mathrm{H}$ ), 5.47 (t, $J=1.2$ $\mathrm{Hz}, 1 \mathrm{H}), 5.36(\mathrm{~s}, 1 \mathrm{H}), 4.80(\mathrm{~d}, J=0.7 \mathrm{~Hz}, 2 \mathrm{H}), 3.85(\mathrm{~s}, 6 \mathrm{H}) .{ }^{13} \mathrm{C} \mathrm{NMR}\left(75 \mathrm{MHz}, \mathrm{CDCl}_{3}\right): \delta$ $168.5,164.8$ (d, $J=251.2 \mathrm{~Hz}), 156.6,134.1,130.2$ (d, $J=8.9 \mathrm{~Hz}), 128.8(\mathrm{~d}, J=3.0 \mathrm{~Hz})$, $116.0,115.0(\mathrm{~d}, J=21.8 \mathrm{~Hz}), 69.9,68.1,53.3$. HRMS (ESI) $(\mathrm{m} / \mathrm{z})$ : calcd for $\mathrm{C}_{15} \mathrm{H}_{14} \mathrm{NO}_{5} \mathrm{~F}$ $[\mathrm{M}+\mathrm{H}]^{+}$308.0929; found 308.0917. 
Dimethyl 2-(4-chlorophenyl)-5-methylidene-5,6-dihydro-4H-1,3-oxazine-4,4-

dicarboxylate (33i). Following General Procedure B, amide $25 \mathrm{i}(57 \mathrm{mg}, 0.2 \mathrm{mmol})$

underwent the palladium-catalysed cyclisation. Purification by flash column chromatography

[hexane:EtOAc 5:1] afforded $33 \mathbf{i}(36 \mathrm{mg}, 56 \%)$ as a colourless solid. $R_{F}=0.45$ [petrol:EtOAc 2:1]. m.p. $92-94{ }^{\circ} \mathrm{C}$. IR (neat): 2953, 1744, 1724, 1634, $1597 \mathrm{~cm}^{-1} .{ }^{1} \mathrm{H}$ NMR $(400 \mathrm{MHz}$, $\left.\mathrm{CDCl}_{3}\right): \delta 7.93(\mathrm{~d}, J=8.8 \mathrm{~Hz}, 2 \mathrm{H}), 7.34(\mathrm{~d}, J=8.9 \mathrm{~Hz}, 2 \mathrm{H}), 5.46(\mathrm{t}, J=1.3 \mathrm{~Hz}, 1 \mathrm{H}), 5.35(\mathrm{~s}$, $1 \mathrm{H}), 4.79(\mathrm{~d}, J=0.7 \mathrm{~Hz}, 2 \mathrm{H}), 3.84(\mathrm{~s}, 6 \mathrm{H}) .{ }^{13} \mathrm{C}$ NMR $\left(100 \mathrm{MHz}, \mathrm{CDCl}_{3}\right): \delta 168.4,156.6$, 137.5, 134.0, 131.1, 129.3, 128.3, 116.1, 69.9, 68.1, 53.3. HRMS (ESI) $(\mathrm{m} / \mathrm{z})$ : calcd for $\mathrm{C}_{15} \mathrm{H}_{14} \mathrm{NO}_{5}{ }^{35} \mathrm{Cl}[\mathrm{M}+\mathrm{H}]+324.0633$; found 324.0622 .

\section{Dimethyl 2-(4-bromophenyl)-5-methylidene-5,6-dihydro-4H-1,3-oxazine-4,4-}

dicarboxylate (33j). A tube was charged with amide $25 \mathrm{j}(66 \mathrm{mg}, 0.20 \mathrm{mmol})$, propargylic electrophile 26 (47 mg, $0.30 \mathrm{mmol}), \mathrm{Pd}_{2} \mathrm{dba}_{3}(9.2 \mathrm{mg}, 0.010 \mathrm{mmol}$ ) and Xantphos (12 mg, $0.020 \mathrm{mmol}) . \mathrm{CH}_{2} \mathrm{Cl}_{2}(2 \mathrm{~mL})$ was added. The tube was sealed and the mixture heated to 60 ${ }^{\circ} \mathrm{C}$ for $15 \mathrm{~h}$. The solution was allowed to cool to room temperature and concentrated in vacuo. Purification by flash column chromatography [hexane:EtOAc 5:1] afforded 33j (26 $\mathrm{mg}, 36 \%$ ) as a brown solid. $R_{F}=0.50$ [petrol:EtOAc 3:1]. m.p. 133-135 ${ }^{\circ} \mathrm{C}$. IR (neat): 2953 , 2886, 1744, $1632 \mathrm{~cm}^{-1}$. ${ }^{1} \mathrm{H}$ NMR $\left(400 \mathrm{MHz}, \mathrm{CDCl}_{3}\right): \delta 7.87(\mathrm{~d}, J=8.7 \mathrm{~Hz}, 2 \mathrm{H}), 7.51(\mathrm{~d}, J=$ $8.8 \mathrm{~Hz}, 2 \mathrm{H}), 5.47(\mathrm{t}, J=1.2 \mathrm{~Hz}, 1 \mathrm{H}), 5.37(\mathrm{~s}, 1 \mathrm{H}), 4.80(\mathrm{~s}, 2 \mathrm{H}), 3.85(\mathrm{~s}, 6 \mathrm{H}) .{ }^{13} \mathrm{C}$ NMR $(100$ $\left.\mathrm{MHz}, \mathrm{CDCl}_{3}\right): \delta 168.4,156.7,133.9,131.5,131.3,129.6,126.1,116.2,69.9,68.2,53.4$. HRMS (ESI) $(\mathrm{m} / \mathrm{z})$ : calcd for $\mathrm{C}_{15} \mathrm{H}_{14} \mathrm{NO}_{5}{ }^{79} \mathrm{Br}[\mathrm{M}+\mathrm{H}]+368.0128$; found 368.0117 .

\section{Dimethyl 2-(furan-2-yl)-5-methylidene-5,6-dihydro-4H-1,3-oxazine-4,4-dicarboxylate} (33k). Following General Procedure B, amide 25k (48 mg, $0.20 \mathrm{mmol}$ ) underwent the palladium-catalysed cyclisation. Purification by flash column chromatography [hexane:EtOAc 2:1] afforded 33k (26 mg, 47\%) as a yellow solid. $R_{F}=0.30$ [petrol:EtOAc 1:1]. m.p. 69-72 ${ }^{\circ} \mathrm{C}$. IR (neat): 2958, 1744, 1722, $1649 \mathrm{~cm}^{-1}$. ${ }^{1} \mathrm{H}$ NMR $\left(400 \mathrm{MHz}, \mathrm{CDCl}_{3}\right): \delta 7.51$ (dd, $J=1.8$, $0.9 \mathrm{~Hz}, 1 \mathrm{H}), 6.94(\mathrm{dd}, J=3.4,0.9 \mathrm{~Hz}, 1 \mathrm{H}), 6.44(\mathrm{dd}, J=3.4,1.8 \mathrm{~Hz}, 1 \mathrm{H}), 5.45(\mathrm{t}, J=1.2 \mathrm{~Hz}$, $1 \mathrm{H}), 5.35(\mathrm{~s}, 1 \mathrm{H}), 4.76(\mathrm{~d}, J=0.6 \mathrm{~Hz}, 2 \mathrm{H}), 3.82(\mathrm{~s}, 6 \mathrm{H}) .{ }^{13} \mathrm{C} \mathrm{NMR}\left(100 \mathrm{MHz}, \mathrm{CDCl}_{3}\right): \delta$ 168.3, 150.5, 146.0, 145.1, 133.9, 116.3, 114.1, 111.4, 69.6, 68.0, 53.4. HRMS (ESI) $(\mathrm{m} / \mathrm{z})$ : calcd for $\mathrm{C}_{13} \mathrm{H}_{13} \mathrm{NO}_{6}[\mathrm{M}+\mathrm{H}]+280.0816$; found 280.0805 .

tert-Butyl but-3-yn-2-yl carbonate (34a). Following General Procedure C, 3-butyn-2-ol $(2.35 \mathrm{~mL}, 30.0 \mathrm{mmol})$ was reacted with di-tert-butyl dicarbonate $(6.54 \mathrm{~g}, 30.0 \mathrm{mmol})$ in the presence of DMAP (183 mg, $1.50 \mathrm{mmol})$ and $\mathrm{Et}_{3} \mathrm{~N}(4.59 \mathrm{~mL}, 33.0 \mathrm{mmol})$ in $\mathrm{CH}_{2} \mathrm{Cl}_{2}(60 \mathrm{~mL})$. Purification by flash column chromatography [petrol:EtOAc 19:1] afforded 34a (2.98 g, 58\%) as a clear oil. $R_{F}=0.55$ [petrol:EtOAc 9:1]. IR (neat): $3293,2983,2123,1739 \mathrm{~cm}^{-1} .{ }^{1} \mathrm{H}$ NMR $\left(400 \mathrm{MHz}, \mathrm{CDCl}_{3}\right): \delta 5.23$ (qd, $\left.J=6.7,2.1 \mathrm{~Hz}, 1 \mathrm{H}\right), 2.46(\mathrm{~d}, J=2.1 \mathrm{~Hz}, 1 \mathrm{H}), 1.52(\mathrm{~d}, J=6.7$ $\mathrm{Hz}, 3 \mathrm{H}), 1.48(\mathrm{~s}, 9 \mathrm{H}) .{ }^{13} \mathrm{C} \mathrm{NMR}\left(100 \mathrm{MHz}, \mathrm{CDCl}_{3}\right): \delta 152.4,82.7,81.8,73.3,62.8,27.7$, 21.2 .

tert-Butyl pent-1-yn-3-yl carbonate (34b). Following General Procedure C, 1-pentyn-3-ol $(860 \mathrm{~mL}, 10.0 \mathrm{mmol})$ was reacted with di-tert-butyl dicarbonate $(2.18 \mathrm{~g}, 10.0 \mathrm{mmol})$ in the presence of DMAP $(61 \mathrm{mg}, 0.50 \mathrm{mmol})$ and $\mathrm{Et}_{3} \mathrm{~N}(1.53 \mathrm{~mL}, 11.0 \mathrm{mmol})$ in $\mathrm{CH}_{2} \mathrm{Cl}_{2}(30 \mathrm{~mL})$. Purification by flash column chromatography [hexane:EtOAc $49: 1]$ afforded $34 \mathrm{~b}(0.71 \mathrm{~g}$, $40 \%$ ) as a clear oil. $R_{F}=0.80$ [petrol:EtOAc 9:1]. IR (neat): 3287, 2978, 2939, 2120, 1738 $\mathrm{cm}^{-1}$. ${ }^{1} \mathrm{H}$ NMR $\left(400 \mathrm{MHz}, \mathrm{CDCl}_{3}\right): \delta 5.09(\mathrm{td}, J=6.6,2.2 \mathrm{~Hz}, 1 \mathrm{H}), 2.47(\mathrm{~d}, J=2.1 \mathrm{~Hz}, 1 \mathrm{H})$, $1.82(\mathrm{pd}, J=7.4,1.0 \mathrm{~Hz}, 2 \mathrm{H}), 1.49(\mathrm{~s}, 9 \mathrm{H}), 1.02(\mathrm{t}, J=7.4 \mathrm{~Hz}, 3 \mathrm{H}) .{ }^{13} \mathrm{C}$ NMR $(100 \mathrm{MHz}$, $\left.\mathrm{CDCl}_{3}\right): \delta 152.6,82.7,80.7,74.0,67.8,27.9,27.7,9.2$.

tert-Butyl dec-1-yn-3-yl carbonate (34c). Following General Procedure C, dec-1-yn-3-ol $(780 \mathrm{mg}, 5.06 \mathrm{mmol})$ was reacted with di-tert-butyl dicarbonate $(1.10 \mathrm{~g}, 5.06 \mathrm{mmol})$ in the 
presence of DMAP (31 mg, $0.25 \mathrm{mmol})$ and $\mathrm{Et}_{3} \mathrm{~N}(780 \mathrm{~mL}, 5.66 \mathrm{mmol})$ in $\mathrm{CH}_{2} \mathrm{Cl}_{2}(15 \mathrm{~mL})$. Purification by flash column chromatography [hexane:EtOAc 49:1] afforded 34c $(0.96 \mathrm{~g}$, $57 \%$ ) as a clear oil containing a small amount of unreacted di-tert-butyl dicarbonate. $R_{F}=$ 0.65 [petrol:EtOAc 9:1]. IR (neat): 3293, 2927, 2857, 2129, $1740 \mathrm{~cm}^{-1}$. ${ }^{1} \mathrm{H} \mathrm{NMR}(400 \mathrm{MHz}$, $\left.\mathrm{CDCl}_{3}\right): \delta 5.13(\mathrm{td}, J=6.7,2.1 \mathrm{~Hz}, 1 \mathrm{H}), 2.46(\mathrm{~d}, J=2.1 \mathrm{~Hz}, 1 \mathrm{H}), 1.84-1.72(\mathrm{~m}, 2 \mathrm{H}), 1.54-$ $1.39(\mathrm{~m}, 11 \mathrm{H}), 1.35-1.18(\mathrm{~m}, 8 \mathrm{H}), 0.86(\mathrm{t}, J=6.4 \mathrm{~Hz}, 3 \mathrm{H}) .{ }^{13} \mathrm{C} \mathrm{NMR}\left(100 \mathrm{MHz}, \mathrm{CDCl}_{3}\right): \delta$ 152.6, 82.6, 81.0, 73.9, 66.7, 31.7, 29.0, 29.0, 27.7, 27.4, 24.8, 22.6, 14.0.

tert-Butyl 1-phenylbut-3-yn-2-yl carbonate (34d). Following General Procedure C, 1phenylbut-3-yn-2-ol (830 mg, $5.67 \mathrm{mmol})$ was reacted with di-tert-butyl dicarbonate $(1.23 \mathrm{~g}$, $5.67 \mathrm{mmol}$ ) in the presence of DMAP $(35 \mathrm{mg}, 0.28 \mathrm{mmol})$ and $\mathrm{Et}_{3} \mathrm{~N}(870 \mathrm{~mL}, 6.24 \mathrm{mmol})$ in $\mathrm{CH}_{2} \mathrm{Cl}_{2}(15 \mathrm{~mL})$. Purification by flash column chromatography [hexane:EtOAc 99:1] afforded 34d $(0.78 \mathrm{~g}, 56 \%)$ as a clear oil. $R_{F}=0.79$ [petrol:EtOAc 9:1]. IR (neat): 3285, 2980, 2933, 2126, $1738 \mathrm{~cm}^{-1}$. ${ }^{1} \mathrm{H}$ NMR $\left(400 \mathrm{MHz}, \mathrm{CDCl}_{3}\right): \delta 7.36-7.23(\mathrm{~m}, 5 \mathrm{H}), 5.39(\mathrm{td}, J=7.0,2.1 \mathrm{~Hz}$, $1 \mathrm{H}), 3.16(\mathrm{dd}, J=13.6,6.9 \mathrm{~Hz}, 1 \mathrm{H}), 3.09(\mathrm{dd}, J=13.6,7.1 \mathrm{~Hz}, 1 \mathrm{H}), 2.51(\mathrm{~d}, J=2.2 \mathrm{~Hz}, 1 \mathrm{H})$, $1.48(\mathrm{~s}, 9 \mathrm{H}) .{ }^{13} \mathrm{C}$ NMR $\left(100 \mathrm{MHz}, \mathrm{CDCl}_{3}\right): \delta 152.2,135.3,129.5,128.2,126.8,82.5,80.2$, 74.8, 67.0, 41.0, 27.5. HRMS (APCl) $(\mathrm{m} / \mathrm{z})$ : calcd for $\mathrm{C}_{15} \mathrm{H}_{18} \mathrm{O}_{3}[\mathrm{M}+\mathrm{Na}]^{+} 296.1148$; found 296.1142.

tert-Butyl 5-(methylsulfanyl)pent-1-yn-3-yl carbonate (34e). Following General Procedure C, 5-(methylsulfanyl)pent-1-yn-3-ol (880 mg, $6.77 \mathrm{mmol})$ was reacted with di-tertbutyl dicarbonate $(1.46 \mathrm{~g}, 6.77 \mathrm{mmol})$ in the presence of DMAP $(41 \mathrm{mg}, 0.34 \mathrm{mmol})$ and $\mathrm{Et}_{3} \mathrm{~N}(980 \mathrm{~mL}, 7.01 \mathrm{mmol})$ in $\mathrm{CH}_{2} \mathrm{Cl}_{2}(15 \mathrm{~mL})$. Purification by flash column chromatography [hexane:EtOAc 49:1] afforded $34 \mathrm{e}(1.03 \mathrm{~g}, 66 \%)$ as a clear oil. $R_{F}=0.75$ [petrol:EtOAc 9:1]. IR (neat): 3285, 2980, 2920, 2124, $1740 \mathrm{~cm}^{-1}$. ${ }^{1} \mathrm{H}$ NMR $\left(400 \mathrm{MHz}, \mathrm{CDCl}_{3}\right): \delta 5.26$ (td, $J=$ 6.6, $2.1 \mathrm{~Hz}, 1 \mathrm{H}), 2.60(\mathrm{t}, J=7.6 \mathrm{~Hz}, 2 \mathrm{H}), 2.49(\mathrm{~d}, J=2.1 \mathrm{~Hz}, 1 \mathrm{H}), 2.14-1.97(\mathrm{~m}, 5 \mathrm{H}), 1.45(\mathrm{~s}$, $9 \mathrm{H}) .{ }^{13} \mathrm{C}$ NMR $\left(100 \mathrm{MHz}, \mathrm{CDCl}_{3}\right): \delta 152.3,82.9,80.2,74.6,65.3,34.1,29.1,27.6,15.3$.

tert-Butyl 5-methylhex-1-yn-3-yl carbonate (34f). Following General Procedure C, 5methyl-1-hexyn-3-ol $(0.52 \mathrm{~mL}, 4.0 \mathrm{mmol})$ was reacted with di-tert-butyl dicarbonate $(0.87 \mathrm{~g}$, $4.0 \mathrm{mmol})$ in the presence of DMAP $(24 \mathrm{mg}, 0.20 \mathrm{mmol})$ and $\mathrm{Et}_{3} \mathrm{~N}(0.61 \mathrm{~mL}, 4.4 \mathrm{mmol})$ in $\mathrm{CH}_{2} \mathrm{Cl}_{2}(30 \mathrm{~mL})$. Purification by flash column chromatography [hexane:EtOAc 99:1] afforded $34 f(0.48 \mathrm{~g}, 57 \%)$ as a clear oil. $R_{F}=0.70$ [petrol:EtOAc 9:1]. IR (neat): 3289, 2959, 2873, 2129, $1738 \mathrm{~cm}^{-1}$. ${ }^{1} \mathrm{H}$ NMR $\left(400 \mathrm{MHz}, \mathrm{CDCl}_{3}\right): \delta 5.17(\mathrm{td}, J=7.3,2.1 \mathrm{~Hz}, 1 \mathrm{H}), 2.45(\mathrm{~d}, J=$ $2.1 \mathrm{~Hz}, 1 \mathrm{H}), 1.86-1.58(\mathrm{~m}, 3 \mathrm{H}), 1.47(\mathrm{~s}, 9 \mathrm{H}), 0.92(\mathrm{~d}, J=6.6 \mathrm{~Hz}, 3 \mathrm{H}), 0.91(\mathrm{~d}, J=6.5 \mathrm{~Hz}$, $3 \mathrm{H}) .{ }^{13} \mathrm{C}$ NMR $\left(100 \mathrm{MHz}, \mathrm{CDCl}_{3}\right): \delta 152.6,82.6,81.1,73.9,65.4,43.4,27.7,24.5,22.4$, 22.1 .

tert-Butyl 1-cyclohexylprop-2-yn-1-yl carbonate (34g). Following General Procedure C, 1-cyclohexylprop-2-yn-1-ol $(0.42 \mathrm{~mL}, 3.0 \mathrm{mmol})$ was reacted with di-tert-butyl dicarbonate $(0.66 \mathrm{~g}, 3.0 \mathrm{mmol})$ in the presence of DMAP $(18 \mathrm{mg}, 0.15 \mathrm{mmol})$ and $\mathrm{Et}_{3} \mathrm{~N}(0.46 \mathrm{~mL}, 3.3$ $\mathrm{mmol}$ ) in $\mathrm{CH}_{2} \mathrm{Cl}_{2}(15 \mathrm{~mL})$. Purification by flash column chromatography [hexane:EtOAc 99:1] afforded $34 \mathrm{~g}(0.59 \mathrm{~g}, 83 \%)$ as a clear oil. $R_{F}=0.74$ [petrol:EtOAc 9:1]. IR (neat): 3287 , 2927, 2855, 2122, $1740 \mathrm{~cm}^{-1}$. ${ }^{1} \mathrm{H}$ NMR $\left(300 \mathrm{MHz}, \mathrm{CDCl}_{3}\right): \delta 4.97$ (dd, $\left.J=6.2,2.2 \mathrm{~Hz}, 1 \mathrm{H}\right)$, $2.45(\mathrm{~d}, J=2.2 \mathrm{~Hz}, 1 \mathrm{H}), 1.91-1.60(\mathrm{~m}, 6 \mathrm{H}), 1.47(\mathrm{~s}, 9 \mathrm{H}), 1.32-1.01(\mathrm{~m}, 5 \mathrm{H}) .{ }^{13} \mathrm{C}$ NMR $(75$ $\left.\mathrm{MHz}, \mathrm{CDCl}_{3}\right): \delta 152.8,82.5,79.9,74.6,71.0,41.6,28.4,27.8,27.0,26.1,25.6,25.6$.

tert-Butyl 4-(1-((tert-butoxycarbonyl)oxy)prop-2-yn-1-yl)piperidine-1-carboxylate (34h). Following General Procedure C, tert-butyl 4-(1-hydroxyprop-2-yn-1-yl)piperidine-1carboxylate $(440 \mathrm{mg}, 1.84 \mathrm{mmol})$ was reacted with di-tert-butyl dicarbonate $(410 \mathrm{mg}, 1.84$ $\mathrm{mmol})$ in the presence of DMAP $(11 \mathrm{mg}, 0.090 \mathrm{mmol})$ and $\mathrm{Et}_{3} \mathrm{~N}(0.28 \mathrm{~mL}, 2.0 \mathrm{mmol})$ in $\mathrm{CH}_{2} \mathrm{Cl}_{2}(15 \mathrm{~mL})$. Purification by flash column chromatography [hexane:EtOAc 6:1] afforded 
34h $(0.22 \mathrm{~g}, 35 \%)$ as a clear oil. $R_{F}=0.75$ [petrol:EtOAc 2:1]. IR (neat): 3283, 2976, 2931, 2119, 1742, $1686 \mathrm{~cm}^{-1}$. ${ }^{1} \mathrm{H}$ NMR $\left(400 \mathrm{MHz}, \mathrm{CDCl}_{3}\right): \delta 4.99$ (dd, $\left.J=6.2,2.2 \mathrm{~Hz}, 1 \mathrm{H}\right), 4.23-$ $4.05(\mathrm{~m}, 2 \mathrm{H}), 2.62(\mathrm{tt}, J=13.1,3.6 \mathrm{~Hz}, 2 \mathrm{H}), 2.47(\mathrm{~d}, J=2.1 \mathrm{~Hz}, 1 \mathrm{H}), 1.91-1.67(\mathrm{~m}, 3 \mathrm{H}), 1.44$ (s, 9H), $1.40(\mathrm{~s}, 9 \mathrm{H}), 1.35-1.29(\mathrm{~m}, 2 \mathrm{H}) .{ }^{13} \mathrm{C} \mathrm{NMR}\left(100 \mathrm{MHz}, \mathrm{CDCl}_{3}\right): \delta$ 154.6, 152.5, 82.8, 79.3, 79.0, 75.2, 69.8, 43.3, 40.1, 28.3, 27.6, 27.0. HRMS (ESI) $(\mathrm{m} / \mathrm{z})$ : calcd for $\mathrm{C}_{18} \mathrm{H}_{29} \mathrm{NO}_{5}$ $[\mathrm{M}+\mathrm{Na}]^{+}$362.1938; found 362.1934.

tert-Butyl 1-cyclopropylprop-2-yn-1-yl carbonate (34i). Following General Procedure C, 1-cyclopropylprop-2-yn-1-ol (410 mg, $4.27 \mathrm{mmol}$ ) was reacted with di-tert-butyl dicarbonate (930 mg, $4.27 \mathrm{mmol})$ in the presence of DMAP $(26 \mathrm{mg}, 0.21 \mathrm{mmol})$ and $\mathrm{Et}_{3} \mathrm{~N}(0.65 \mathrm{~mL}, 4.7$ $\mathrm{mmol})$ in $\mathrm{CH}_{2} \mathrm{Cl}_{2}(15 \mathrm{~mL})$. Purification by flash column chromatography [hexane:EtOAc 49:1] afforded $34 \mathbf{i}(0.59 \mathrm{~g}, 70 \%)$ as a clear oil containing a small amount of unreacted di-tert-butyl dicarbonate. $R_{F}=0.79$ [petrol:EtOAc 9:1]. IR (neat): 3291, 2981, 2935, 2123, $1736 \mathrm{~cm}^{-1} .{ }^{1} \mathrm{H}$ $\operatorname{NMR}\left(400 \mathrm{MHz}, \mathrm{CDCl}_{3}\right): \delta 5.00(\mathrm{dd}, J=7.0,2.2 \mathrm{~Hz}, 1 \mathrm{H}), 2.44(\mathrm{~d}, J=2.2 \mathrm{~Hz}, 1 \mathrm{H}), 1.49$ (s, $9 \mathrm{H}), 1.36-1.26(\mathrm{~m}, 1 \mathrm{H}), 0.64-0.48(\mathrm{~m}, 4 \mathrm{H}) .{ }^{13} \mathrm{C} \mathrm{NMR}\left(100 \mathrm{MHz}, \mathrm{CDCl}_{3}\right): \delta$ 152.6, 82.7, 78.8, $74.1,70.2,27.7,14.1,3.5,2.2$.

tert-Butyl 4-methylpent-1-yn-3-yl carbonate (34j). Following General Procedure C, 4methylpent-1-yn-3-ol (810 mg, $8.25 \mathrm{mmol})$ was reacted with di-tert-butyl dicarbonate $(1.80 \mathrm{~g}$, $8.25 \mathrm{mmol})$ in the presence of DMAP $(50 \mathrm{mg}, 0.41 \mathrm{mmol})$ and $\mathrm{Et}_{3} \mathrm{~N}(1.26 \mathrm{~mL}, 9.07 \mathrm{mmol})$ in $\mathrm{CH}_{2} \mathrm{Cl}_{2}(15 \mathrm{~mL})$. Purification by flash column chromatography [hexane:EtOAc 99:1] afforded 34j $(1.13 \mathrm{~g}, 70 \%)$ as a clear oil. $R_{F}=0.83$ [petrol:EtOAc 9:1]. IR (neat): 3293, 2980, 2935, 2134, $1742 \mathrm{~cm}^{-1}$. ${ }^{1} \mathrm{H}$ NMR $\left(300 \mathrm{MHz}, \mathrm{CDCl}_{3}\right): \delta 5.01$ (dd, $\left.J=5.8,2.2 \mathrm{~Hz}, 1 \mathrm{H}\right), 2.46(\mathrm{~d}, J=$ $2.2 \mathrm{~Hz}, 1 \mathrm{H}), 2.13-1.96(\mathrm{~m}, 1 \mathrm{H}), 1.50(\mathrm{~s}, 9 \mathrm{H}), 1.05(\mathrm{~d}, J=6.7 \mathrm{~Hz}, 3 \mathrm{H}), 1.01(\mathrm{~d}, J=6.8 \mathrm{~Hz}$, $3 \mathrm{H}) .{ }^{13} \mathrm{C} \mathrm{NMR}\left(75 \mathrm{MHz}, \mathrm{CDCl}_{3}\right): \delta 152.8,82.7,79.6,74.6,71.7,32.3,27.8,18.1,17.4$.

tert-Butyl 4,4-dimethylpent-1-yn-3-yl carbonate (34k). Following General Procedure C, 4,4-dimethylpent-1-yn-3-ol $(860 \mathrm{mg}, 7.67 \mathrm{mmol})$ was reacted with di-tert-butyl dicarbonate $(1.68 \mathrm{~g}, 7.67 \mathrm{mmol})$ in the presence of DMAP $(47 \mathrm{mg}, 0.38 \mathrm{mmol})$ and $\mathrm{Et}_{3} \mathrm{~N}(1.17 \mathrm{~mL}, 8.44$ $\mathrm{mmol}$ ) in $\mathrm{CH}_{2} \mathrm{Cl}_{2}(15 \mathrm{~mL})$. Purification by flash column chromatography [hexane:EtOAc 49:1] afforded $34 \mathbf{k}(0.97 \mathrm{~g}, 57 \%)$ as a clear oil containing a small amount of unreacted di-tert-butyl dicarbonate. $R_{F}=0.67$ [petrol:EtOAc 9:1]. IR (neat): 3289, 2974, 2937, 2122, $1742 \mathrm{~cm}^{-1} .{ }^{1} \mathrm{H}$ $\operatorname{NMR}\left(400 \mathrm{MHz}, \mathrm{CDCl}_{3}\right): \delta$ 4.91-4.88 (m, 1H), $2.43(\mathrm{~d}, J=2.1 \mathrm{~Hz}, 1 \mathrm{H}), 1.47(\mathrm{~s}, 9 \mathrm{H}), 1.01$ (s, 9H). ${ }^{13} \mathrm{C} \mathrm{NMR}\left(100 \mathrm{MHz}, \mathrm{CDCl}_{3}\right): \delta 153.1,82.1,79.7,74.6,74.5,27.7,27.4,25.3$.

tert-Butyl 1-(3,4-dimethoxyphenyl)prop-2-yn-1-yl carbonate (34p). Following General Procedure C, 1-(3,4-dimethoxyphenyl)prop-2-yn-1-ol (730 mg, $3.78 \mathrm{mmol}$ ) was reacted with di-tert-butyl dicarbonate $(910 \mathrm{mg}, 4.16 \mathrm{mmol})$ in the presence of DMAP (46 mg, $0.38 \mathrm{mmol}$ ) and $\mathrm{Et}_{3} \mathrm{~N}(660 \mathrm{~mL}, 4.73 \mathrm{mmol})$ in $\mathrm{CH}_{2} \mathrm{Cl}_{2}(30 \mathrm{~mL})$. Purification by flash column chromatography [hexane:EtOAc 6:1] afforded $34 \mathrm{p}(1.05 \mathrm{~g}, 95 \%)$ as a cream solid. $R_{F}=0.29$ [petrol:EtOAc 4:1]. m.p. 115-116 ${ }^{\circ} \mathrm{C}$. IR (neat): 3295, 2988, 2963, 2126, 1734, 1593, 1508 $\mathrm{cm}^{-1}$. ${ }^{1} \mathrm{H}$ NMR $\left(400 \mathrm{MHz}, \mathrm{CDCl}_{3}\right): \delta 7.12-7.06(\mathrm{~m}, 2 \mathrm{H}), 6.84(\mathrm{~d}, J=8.2 \mathrm{~Hz}, 1 \mathrm{H}), 6.18(\mathrm{~d}, J=$ $2.3 \mathrm{~Hz}, 1 \mathrm{H}), 3.90(\mathrm{~s}, 3 \mathrm{H}), 3.87(\mathrm{~s}, 3 \mathrm{H}), 2.69(\mathrm{~d}, \mathrm{~J}=2.3 \mathrm{~Hz}, 1 \mathrm{H}), 1.48(\mathrm{~s}, 9 \mathrm{H}) .{ }^{13} \mathrm{C}$ NMR $(100$ $\left.\mathrm{MHz}, \mathrm{CDCl}_{3}\right): \delta 152.4,149.7,149.0,128.7,120.6,110.8,110.8,83.1,80.1,75.8,68.2,55.9$, $55.9,27.7$.

Methyl 4-(1-((tert-butoxycarbonyl)oxy)prop-2-yn-1-yl)benzoate (34s). Following General Procedure C, methyl 4-(1-hydroxyprop-2-yn-1-yl)benzoate $(740 \mathrm{mg}, 3.89 \mathrm{mmol})$ was reacted with di-tert-butyl dicarbonate $(930 \mathrm{mg}, 4.28 \mathrm{mmol}$ ) in the presence of DMAP (48 $\mathrm{mg}, 0.39$ $\mathrm{mmol})$ and $\mathrm{Et}_{3} \mathrm{~N}(680 \mathrm{~mL}, 4.86 \mathrm{mmol})$ in $\mathrm{CH}_{2} \mathrm{Cl}_{2}(30 \mathrm{~mL})$. Purification by flash column chromatography [hexane:EtOAc 9:1] afforded $34 \mathrm{~s}(0.99 \mathrm{~g}, 88 \%)$ as a clear oil. $R_{F}=0.23$ [petrol:EtOAc 4:1]. IR (neat): 3288, 2954, 2982, 2126, $1720 \mathrm{~cm}^{-1} .{ }^{1} \mathrm{H}$ NMR $(400 \mathrm{MHz}$, 
$\left.\mathrm{CDCl}_{3}\right): \delta 8.05(\mathrm{~d}, J=8.5 \mathrm{~Hz}, 2 \mathrm{H}), 7.60(\mathrm{~d}, J=8.0 \mathrm{~Hz}, 2 \mathrm{H}), 6.26(\mathrm{~d}, J=2.3 \mathrm{~Hz}, 1 \mathrm{H}), 3.91$ (s, $3 \mathrm{H}), 2.71(\mathrm{~d}, J=2.3 \mathrm{~Hz}, 1 \mathrm{H}), 1.48(\mathrm{~s}, 9 \mathrm{H}) .{ }^{13} \mathrm{C} \mathrm{NMR}\left(100 \mathrm{MHz}, \mathrm{CDCl}_{3}\right): \delta 166.5,152.2$, 140.9, 130.7, 129.9, 127.5, 83.5, 79.4, 76.5, 67.5, 52.2, 27.7. HRMS (ESI) (m/z): calcd for $\mathrm{C}_{16} \mathrm{H}_{18} \mathrm{O}_{5}[2 \mathrm{M}+\mathrm{Na}]^{+} 603.2201$; found 603.2181 .

tert-Butyl 1,1-diphenylprop-2-yn-1-yl carbonate (34w). Following General Procedure C, 1,1-diphenylprop-2-yn-1-ol $(1.46 \mathrm{~g}, 10.0 \mathrm{mmol})$ was reacted with di-tert-butyl dicarbonate $(2.18 \mathrm{~g}, 10.0 \mathrm{mmol})$ in the presence of DMAP $(61 \mathrm{mg}, 0.50 \mathrm{mmol})$ and $\mathrm{Et}_{3} \mathrm{~N}(1.53 \mathrm{~mL}, 11.0$ $\mathrm{mmol})$ in $\mathrm{CH}_{2} \mathrm{Cl}_{2}(30 \mathrm{~mL})$. Purification by flash column chromatography [hexane:EtOAc 99:1] afforded 34w (1.76 g, $60 \%)$ as an orange solid. $R_{F}=0.53$ [petrol:EtOAc 9:1]. m.p. 98-102 ${ }^{\circ} \mathrm{C}$. IR (neat): 3280, 2981, 2115, $1755 \mathrm{~cm}^{-1}$. ${ }^{1} \mathrm{H}$ NMR $\left(400 \mathrm{MHz}, \mathrm{CDCl}_{3}\right): \delta 7.55$ (dd, J= 8.4, $1.3 \mathrm{~Hz}, 4 \mathrm{H}$ ), $7.33(\mathrm{tt}, J=7.3,1.6 \mathrm{~Hz}, 4 \mathrm{H}), 7.27(\mathrm{tt}, J=7.2,1.4 \mathrm{~Hz}, 2 \mathrm{H}), 3.00(\mathrm{~s}, 1 \mathrm{H}), 1.42(\mathrm{~s}$, 9H). ${ }^{13} \mathrm{C}$ NMR $\left(100 \mathrm{MHz}, \mathrm{CDCl}_{3}\right): \delta 150.7,140.0,128.2,128.0,126.1,82.9,82.5,80.3,78.0$, 27.7.

\section{Dimethyl 6-methyl-5-methylidene-2-phenyl-5,6-dihydro-4H-1,3-oxazine-4,4-}

dicarboxylate (35a). Following General Procedure D, propargylic carbonate 34a (51 mg, $0.30 \mathrm{mmol}$ ) underwent the palladium-catalysed cyclisation. Purification by flash column chromatography [hexane:EtOAc 9:1] afforded $35 \mathrm{a}(53.5 \mathrm{mg}, 88 \%)$ as a colourless crystalline solid. Following General Procedure F, propargylic carbonate $34 a(38 \mathrm{mg}, 0.23 \mathrm{mmol}$ ) underwent the enantioselective palladium-catalysed cyclisation. Purification by flash column chromatography [hexane:EtOAc 9:1] afforded 35a (41 mg, 90\%). $R_{F}=0.38$ [petrol:EtOAc 2:1]. m.p. $80-82^{\circ} \mathrm{C}$. IR (neat): 2954, 1739, $1646 \mathrm{~cm}^{-1}$. ${ }^{1} \mathrm{H}$ NMR $\left(400 \mathrm{MHz}, \mathrm{CDCl}_{3}\right): \delta 8.00$ (d, $J=7.0 \mathrm{~Hz}, 2 \mathrm{H}), 7.45(\mathrm{t}, J=7.3 \mathrm{~Hz}, 1 \mathrm{H}), 7.37(\mathrm{t}, J=7.4 \mathrm{~Hz}, 2 \mathrm{H}), 5.47(\mathrm{~d}, J=1.0 \mathrm{~Hz}, 1 \mathrm{H})$, $5.36(\mathrm{~s}, 1 \mathrm{H}), 4.91(\mathrm{q}, J=6.3 \mathrm{~Hz}, 1 \mathrm{H}), 3.85(\mathrm{~s}, 3 \mathrm{H}), 3.82(\mathrm{~s}, 3 \mathrm{H}), 1.60(\mathrm{~d}, J=6.3 \mathrm{~Hz}, 3 \mathrm{H}) .{ }^{13} \mathrm{C}$ $\operatorname{NMR}\left(100 \mathrm{MHz}, \mathrm{CDCl}_{3}\right): \delta 169.1,168.9,157.7,138.7,132.7,131.2,128.0,128.0,114.1$, 71.5, 71.3, 53.4, 53.2, 17.6. HRMS (ESI) $(\mathrm{m} / \mathrm{z})$ : calcd for $\mathrm{C}_{16} \mathrm{H}_{17} \mathrm{NO}_{5}[\mathrm{M}+\mathrm{H}]^{+} 304.1179$; found 304.1169. Chiral HPLC: CHIRALPAK AD-H, $1 \mathrm{~mL} / \mathrm{min}, 90: 10$ hexane:i-PrOH, $30^{\circ} \mathrm{C}, t_{\mathrm{A}}$ $($ minor $)=6.2 \mathrm{~min}, t_{\mathrm{B}}($ major $)=7.3 \mathrm{~min}, 47 \%$ ee. $[\alpha]_{\mathrm{D}}^{20}=+250.0\left(c=0.30, \mathrm{CHCl}_{3}\right)$.

Dimethyl (benzoylamino)(buta-1,3-dien-2-yl)propanedioate (37). A tube was charged with amide $25 \mathrm{a}$ (50 mg, $0.20 \mathrm{mmol})$, propargylic electrophile $34 \mathrm{a}(51 \mathrm{mg}, 0.30 \mathrm{mmol})$, $\mathrm{Pd}_{2} \mathrm{dba}_{3}(9.2 \mathrm{mg}, 0.010 \mathrm{mmol}$ ) and Xantphos (12 mg, $0.020 \mathrm{mmol})$. THF (2 mL) was added. The tube was sealed and the mixture heated at $80^{\circ} \mathrm{C}$ for $15 \mathrm{~h}$. The solution was allowed to cool to room temperature and concentrated in vacuo. Purification by flash column chromatography [hexane:EtOAc 9:1-4:1] afforded 35a (41 mg, 68\%), as well as b-hydride eliminated product $37(10 \mathrm{mg}, 17 \%)$ as a sticky yellow oil. $R_{F}=0.28$ [petrol:EtOAc 2:1]. IR (neat): $3414,2953,1737,1670,1508 \mathrm{~cm}^{-1}$. ${ }^{1} \mathrm{H}$ NMR $\left(400 \mathrm{MHz}, \mathrm{CDCl}_{3}\right): \delta 7.84$ (dd, $J=8.4$, $1.4 \mathrm{~Hz}, 2 \mathrm{H}), 7.54$ (tt, $J=7.4,1.3 \mathrm{~Hz}, 1 \mathrm{H}), 7.49-7.41(\mathrm{~m}, 3 \mathrm{H}), 6.55$ (dd, $J=17.3,10.9 \mathrm{~Hz}$, $1 \mathrm{H}), 5.59(\mathrm{~d}, J=1.1 \mathrm{~Hz}, 1 \mathrm{H}), 5.45(\mathrm{dd}, J=17.3,1.4 \mathrm{~Hz}, 1 \mathrm{H}), 5.36(\mathrm{~s}, 1 \mathrm{H}), 5.11(\mathrm{dd}, J=10.9$, $1.5 \mathrm{~Hz}, 1 \mathrm{H}), 3.84(\mathrm{~s}, 6 \mathrm{H}) .{ }^{13} \mathrm{C} \mathrm{NMR}\left(100 \mathrm{MHz} \mathrm{CDCl}_{3}\right)$ : $\delta 167.4,165.9,141.4,135.1,133.2$, 132.1, 128.7, 127.2, 116.7, 116.3, 68.9, 53.6. HRMS (ESI) $(\mathrm{m} / \mathrm{z})$ : calcd for $\mathrm{C}_{16} \mathrm{H}_{17} \mathrm{NO}_{5}$ $[\mathrm{M}+\mathrm{H}]+304.1179$; found 304.1169 .

Dimethyl 6-ethyl-5-methylidene-2-phenyl-5,6-dihydro-4H-1,3-oxazine-4,4-dicarboxylate (35b). Following General Procedure D, propargylic carbonate 34b (55 mg, $0.30 \mathrm{mmol}$ ) underwent the palladium-catalysed cyclisation. Purification by flash column chromatography [hexane:EtOAc 3:1] afforded 35b (51.5 mg, 80\%) as a brown solid. Following General Procedure F, propargylic carbonate $34 \mathrm{~b}(41 \mathrm{mg}, 0.23 \mathrm{mmol})$ underwent the enantioselective palladium-catalysed cyclisation. Purification by flash column chromatography [hexane:EtOAc 7:1] afforded 35b (47 mg, 98\%). $R_{F}=0.41$ [petrol:EtOAc 3:1]. m.p. $90-91^{\circ} \mathrm{C}$. IR (neat): 2953, 2849, 1738, $1645 \mathrm{~cm}^{-1}$. ${ }^{1} \mathrm{H}$ NMR $\left(400 \mathrm{MHz}, \mathrm{CDCl}_{3}\right): \delta 8.02(\mathrm{~d}, J=8.1 \mathrm{~Hz}, 2 \mathrm{H}), 7.46$ (t, 
$J=7.3 \mathrm{~Hz}, 1 \mathrm{H}), 7.39(\mathrm{t}, J=7.8 \mathrm{~Hz}, 2 \mathrm{H}), 5.45(\mathrm{~s}, 1 \mathrm{H}), 5.38(\mathrm{~s}, 1 \mathrm{H}), 4.65$ (dd, $J=8.4,4.9 \mathrm{~Hz}$, $1 \mathrm{H}), 3.85(\mathrm{~s}, 3 \mathrm{H}), 3.82(\mathrm{~s}, 3 \mathrm{H}), 2.00-1.80(\mathrm{~m}, 2 \mathrm{H}), 1.15(\mathrm{t}, J=7.4 \mathrm{~Hz}, 3 \mathrm{H}) .{ }^{13} \mathrm{C}$ NMR $(75$ $\left.\mathrm{MHz}, \mathrm{CDCl}_{3}\right): \delta 169.1,168.9,157.5,137.5,132.9,131.2,128.0,128.0,114.8,77.0,71.1$, 53.4, 53.2, 25.2, 9.9. HRMS (ESI) $(\mathrm{m} / \mathrm{z})$ : calcd for $\mathrm{C}_{17} \mathrm{H}_{19} \mathrm{NO}_{5}[\mathrm{M}+\mathrm{H}]^{+} 318.1336$; found 318.1331. Chiral HPLC: CHIRALPAK AD-H, $1 \mathrm{~mL} / \mathrm{min}, 90: 10$ hexane:i-PrOH, $30{ }^{\circ} \mathrm{C}, t_{\mathrm{A}}$ $($ minor $)=5.9 \mathrm{~min}, t_{\mathrm{B}}($ major $)=6.5 \mathrm{~min}, 44 \%$ ee. $[\alpha]_{\mathrm{D}}^{20}=+20.0\left(c=0.10, \mathrm{CHCl}_{3}\right)$.

\section{Dimethyl 6-heptyl-5-methylidene-2-phenyl-5,6-dihydro-4H-1,3-oxazine-4,4-} dicarboxylate (35c). Following General Procedure D, propargylic carbonate 34c $(76 \mathrm{mg}$, $0.30 \mathrm{mmol}$ ) underwent the palladium-catalysed cyclisation. Purification by flash column chromatography [hexane:EtOAc $7: 1$ ] afforded $35 \mathrm{c}(70.5 \mathrm{mg}, 91 \%)$ as a brown solid. $R_{F}=$ 0.54 [petrol:EtOAc 3:1]. m.p. 111-112 ${ }^{\circ} \mathrm{C}$. IR (neat): 2928, 2855, 1736, $1645 \mathrm{~cm}^{-1} .{ }^{1} \mathrm{H}$ NMR $\left(400 \mathrm{MHz}, \mathrm{CDCl}_{3}\right): \delta 8.00(\mathrm{~d}, J=8.5 \mathrm{~Hz}, 2 \mathrm{H}), 7.46(\mathrm{tt}, J=7.4,1.3 \mathrm{~Hz}, 1 \mathrm{H}), 7.38(\mathrm{tt}, J=7.3$, $1.3 \mathrm{~Hz}, 2 \mathrm{H}), 5.45(\mathrm{~d}, J=0.7 \mathrm{~Hz}, 1 \mathrm{H}), 5.37(\mathrm{~s}, 1 \mathrm{H}), 4.71(\mathrm{t}, J=7.1 \mathrm{~Hz}, 1 \mathrm{H}), 3.85(\mathrm{~s}, 3 \mathrm{H}), 3.82$ $(\mathrm{s}, 3 \mathrm{H}), 1.89-1.80(\mathrm{~m}, 2 \mathrm{H}), 1.66(\mathrm{tt}, J=14.9,6.8 \mathrm{~Hz}, 1 \mathrm{H}), 1.56-1.45(\mathrm{~m}, 1 \mathrm{H}), 1.44-1.22(\mathrm{~m}$, $8 \mathrm{H}), 0.89(\mathrm{t}, J=6.8 \mathrm{~Hz}, 3 \mathrm{H}) .{ }^{13} \mathrm{C}$ NMR $\left(100 \mathrm{MHz} \mathrm{CDCl}_{3}\right): \delta 169.1,168.9,157.6,137.8$, 132.9, 131.2, 128.1, 128.0, 114.7, 75.7, 71.2, 53.4, 53.2, 31.9, 31.8, 29.4, 29.2, 25.4, 22.6, 14.1. HRMS (ESI) $(\mathrm{m} / \mathrm{z})$ : calcd for $\mathrm{C}_{22} \mathrm{H}_{29} \mathrm{NO}_{5}[\mathrm{M}+\mathrm{H}]+388.2118$; found 388.2106.

\section{Dimethyl 6-benzyl-5-methylidene-2-phenyl-5,6-dihydro-4H-1,3-oxazine-4,4-} dicarboxylate (35d). Following General Procedure D, propargylic carbonate $\mathbf{3 4 d}$ (74 mg, $0.30 \mathrm{mmol}$ ) underwent the palladium-catalysed cyclisation. Purification by flash column chromatography [hexane:EtOAc 5:1] afforded $35 \mathrm{~d}(66.5 \mathrm{mg}, 87 \%)$ as a brown solid. Following General Procedure F, propargylic carbonate $34 \mathrm{~d}(55.5 \mathrm{mg}, 0.23 \mathrm{mmol})$ underwent the enantioselective palladium-catalysed cyclisation. Purification by flash column chromatography [hexane:EtOAc 5:1] afforded 35d (50 mg, 88\%). $R_{F}=0.44$ [petrol:EtOAc 3:1]. m.p. $123-128{ }^{\circ} \mathrm{C}$. IR (neat): $3026,2950,1729,1645 \mathrm{~cm}^{-1} .{ }^{1} \mathrm{H}$ NMR $\left(300 \mathrm{MHz}, \mathrm{CDCl}_{3}\right)$ : $\delta 7.87(\mathrm{dd}, J=8.4,1.4 \mathrm{~Hz}, 2 \mathrm{H}), 7.44(\mathrm{tt}, J=7.3,1.4 \mathrm{~Hz}, 1 \mathrm{H}), 7.40-7.27(\mathrm{~m}, 7 \mathrm{H}), 5.52(\mathrm{~s}$, $1 \mathrm{H}), 5.45(\mathrm{~s}, 1 \mathrm{H}), 4.98(\mathrm{ddt}, J=9.4,5.1,1.1 \mathrm{~Hz}, 1 \mathrm{H}), 3.88(\mathrm{~s}, 3 \mathrm{H}), 3.82(\mathrm{~s}, 3 \mathrm{H}), 3.26(\mathrm{dd}, J=$ $14.1,4.3 \mathrm{~Hz}, 1 \mathrm{H}), 3.11(\mathrm{dd}, J=14.1,9.4 \mathrm{~Hz}, 1 \mathrm{H}) .{ }^{13} \mathrm{C} \mathrm{NMR}\left(75 \mathrm{MHz}, \mathrm{CDCl}_{3}\right): \delta 169.0$, 168.8, 157.4, 137.4, 136.9, 132.5, 131.3, 129.4, 128.4, 128.0, 128.0, 126.8, 115.3, 76.2, 71.1, 53.4, 53.2, 38.5. HRMS (ESI) $(\mathrm{m} / \mathrm{z})$ : calcd for $\mathrm{C}_{22} \mathrm{H}_{21} \mathrm{NO}_{5}[\mathrm{M}+\mathrm{H}]+380.1492$; found 380.1495. Chiral HPLC: CHIRALPAK AD-H, $1 \mathrm{~mL} / \mathrm{min}, 90: 10$ hexane:i-PrOH, $30^{\circ} \mathrm{C}, t_{\mathrm{A}}$ $($ major $)=8.3 \mathrm{~min}, t_{\mathrm{B}}(\operatorname{minor})=9.1 \mathrm{~min}, 8 \%$ ee. $[\alpha]_{\mathrm{D}}^{20}=-2.3\left(c=0.44, \mathrm{CHCl}_{3}\right)$.

\section{Dimethyl 5-methylidene-6-(2-(methylsulfanyl)ethyl)-2-phenyl-5,6-dihydro-4H-1,3-} oxazine-4,4-dicarboxylate (35e). Following General Procedure D, propargylic carbonate $34 \mathrm{e}(69 \mathrm{mg}, 0.30 \mathrm{mmol})$ underwent the palladium-catalysed cyclisation. Purification by flash column chromatography [hexane:EtOAc 7:1] afforded $35 \mathrm{e}(58.5 \mathrm{mg}, 80 \%)$ as a brown solid. $R_{F}=0.54$ [petrol:EtOAc 3:1]. m.p. 99-102 ${ }^{\circ} \mathrm{C}$. IR (neat): 2950, 2916, 1735, $1643 \mathrm{~cm}^{-1} .{ }^{1} \mathrm{H}$ $\operatorname{NMR}\left(400 \mathrm{MHz}, \mathrm{CDCl}_{3}\right): \delta 7.99(\mathrm{dd}, J=8.5,1.4 \mathrm{~Hz}, 2 \mathrm{H}), 7.46(\mathrm{tt}, J=7.1,1.3 \mathrm{~Hz}, 1 \mathrm{H}), 7.38$ (tt, $J=7.4,1.7 \mathrm{~Hz}, 2 \mathrm{H}$ ), 5.47 (dd, $J=1.5,0.8 \mathrm{~Hz}, 1 \mathrm{H}$ ), 5.41 (t, $J=0.9 \mathrm{~Hz}, 1 \mathrm{H}$ ), 4.92 (tdd, $J=$ 6.7, 2.2, $1.1 \mathrm{~Hz}, 1 \mathrm{H}), 3.84(\mathrm{~s}, 3 \mathrm{H}), 3.82(\mathrm{~s}, 3 \mathrm{H}), 2.85-2.67(\mathrm{~m}, 2 \mathrm{H}), 2.18-2.10(\mathrm{~m}, 5 \mathrm{H}) .{ }^{13} \mathrm{C}$ $\operatorname{NMR}\left(100 \mathrm{MHz}, \mathrm{CDCl}_{3}\right): \delta 168.9,168.7,157.1,137.1,132.6,131.3,128.1,127.9,115.1$, 74.1, 70.9, 53.4, 53.3, 31.7, 29.9, 15.6. HRMS (ESI) $(\mathrm{m} / \mathrm{z})$ : calcd for $\mathrm{C}_{18} \mathrm{H}_{21} \mathrm{NO}_{5} \mathrm{~S}[\mathrm{M}+\mathrm{H}]^{+}$ 364.1212; found 364.1200 .

Dimethyl 5-methylidene-6-(2-methylpropyl)-2-phenyl-5,6-dihydro-4H-1,3-oxazine-4,4dicarboxylate (35f). Following General Procedure D, propargylic carbonate $34 \mathrm{f}(64 \mathrm{mg}$, $0.30 \mathrm{mmol}$ ) underwent the palladium-catalysed cyclisation. Purification by flash column chromatography [hexane:EtOAc 6:1] afforded $\mathbf{3 5 f}$ (53 $\mathrm{mg}, 77 \%)$ as a brown solid. Following General Procedure F, propargylic carbonate $34 \mathrm{f}(48 \mathrm{mg}, 0.23 \mathrm{mmol})$ underwent the 
enantioselective palladium-catalysed cyclisation. Purification by flash column chromatography [hexane:EtOAc 6:1] afforded $35 f(45.5 \mathrm{mg}, 88 \%) . R_{F}=0.50$ [petrol:EtOAc 3:1]. m.p. $104-108{ }^{\circ} \mathrm{C}$. IR (neat): $2953,1731,1643 \mathrm{~cm}^{-1}$. ${ }^{1} \mathrm{H} \mathrm{NMR}\left(400 \mathrm{MHz}, \mathrm{CDCl}_{3}\right): \delta 8.00$ (dd, $J=8.4,1.3 \mathrm{~Hz}, 2 \mathrm{H}$ ), 7.45 (tt, $J=7.2,1.3 \mathrm{~Hz}, 1 \mathrm{H}$ ), 7.38 (tt, $J=7.1,1.6 \mathrm{~Hz}, 2 \mathrm{H}$ ), 5.45 (dd, $J=1.5,0.7 \mathrm{~Hz}, 1 \mathrm{H}$ ), $5.36(\mathrm{t}, J=0.8 \mathrm{~Hz}, 1 \mathrm{H}), 4.79$ (ddt, $J=9.6,4.4,1.2 \mathrm{~Hz}, 1 \mathrm{H}), 3.84(\mathrm{~s}, 3 \mathrm{H})$, $3.82(\mathrm{~s}, 3 \mathrm{H}), 2.09-1.96(\mathrm{~m}, 1 \mathrm{H}), 1.81$ (ddd, $J=13.9,9.6,5.3 \mathrm{~Hz}, 1 \mathrm{H}), 1.63$ (ddd, $J=13.9$, 8.8, 4.3 Hz, $1 \mathrm{H}), 1.02(\mathrm{t}, J=6.6 \mathrm{~Hz}, 6 \mathrm{H}) .{ }^{13} \mathrm{C}$ NMR $\left(100 \mathrm{MHz}, \mathrm{CDCl}_{3}\right): \delta 169.0,168.8,157.6$, 138.1, 132.8, 131.2, 128.0, 128.0, 114.6, 73.7, 71.2, 53.4, 53.2, 40.6, 24.3, 23.4, 21.7. HRMS (ESI) $(\mathrm{m} / \mathrm{z})$ : calcd for $\mathrm{C}_{19} \mathrm{H}_{23} \mathrm{NO}_{5}[\mathrm{M}+\mathrm{H}]+346.1649$; found 346.1635. Chiral HPLC: CHIRALCEL OJ-H, $1 \mathrm{~mL} / \mathrm{min}, 90: 10$ hexane: $i-\mathrm{PrOH}, 30^{\circ} \mathrm{C}, t_{\mathrm{A}}$ (major) $=7.2 \mathrm{~min}, t_{\mathrm{B}}$ (minor) $=$ $8.4 \mathrm{~min}, 3 \%$ ee. $[\alpha]_{\mathrm{D}}{ }^{20}=+14.6\left(c=0.45, \mathrm{CHCl}_{3}\right)$.

Dimethyl 5-methylidene-6-(2-methylpropyl)-2-phenyl-5,6-dihydro-4H-1,3-oxazine-4,4dicarboxylate (35g). Following General Procedure D, propargylic carbonate $\mathbf{3 4 g}(71 \mathrm{mg}$, $0.30 \mathrm{mmol}$ ) underwent the palladium-catalysed cyclisation. Purification by flash column chromatography [hexane:EtOAc 7:1] afforded $\mathbf{3 5 g}(71.5 \mathrm{mg}, 96 \%)$ as a brown solid. $R_{F}=$ 0.56 [petrol:EtOAc 3:1]. m.p. 150-152 ${ }^{\circ} \mathrm{C}$. IR (neat): 2924, 2851, 1738, $1643 \mathrm{~cm}^{-1} .{ }^{1} \mathrm{H}$ NMR $\left(400 \mathrm{MHz}, \mathrm{CDCl}_{3}\right): \delta 8.03$ (dd, $\left.J=8.5,1.4 \mathrm{~Hz}, 2 \mathrm{H}\right), 7.46(\mathrm{tt}, J=7.3,1.4 \mathrm{~Hz}, 1 \mathrm{H}), 7.39(\mathrm{t}, J=$ $7.3 \mathrm{~Hz}, 2 \mathrm{H}), 5.45(\mathrm{~s}, 1 \mathrm{H}), 5.39(\mathrm{~d}, J=1.3 \mathrm{~Hz}, 1 \mathrm{H}), 4.42(\mathrm{~d}, J=8.4 \mathrm{~Hz}, 1 \mathrm{H}), 3.83(\mathrm{~s}, 3 \mathrm{H}), 3.80$ $(\mathrm{s}, 3 \mathrm{H}), 2.10-2.00(\mathrm{~m}, 1 \mathrm{H}), 1.83-1.61(\mathrm{~m}, 4 \mathrm{H}), 1.32-1.01(\mathrm{~m}, 6 \mathrm{H}) .{ }^{13} \mathrm{C} N M R(100 \mathrm{MHz}$, $\left.\mathrm{CDCl}_{3}\right): \delta 169.0,168.8,157.0,135.4,132.9,131.2,128.1,128.0,117.1,81.9,70.6,53.4$, 53.2, 39.1, 29.6, 28.8, 26.2, 25.9, 25.6. HRMS (ESI) $(\mathrm{m} / \mathrm{z})$ : calcd for $\mathrm{C}_{21} \mathrm{H}_{25} \mathrm{NO}_{5}[\mathrm{M}+\mathrm{H}]^{+}$ 372.1805 ; found 372.1794 .

Dimethyl 6-(1-(tert-butoxycarbonyl)piperidin-4-yl)-5-methylidene-2-phenyl-5,6-dihydro4H-1,3-oxazine-4,4-dicarboxylate (35h). Following General Procedure D, propargylic carbonate $34 \mathrm{~h}(101 \mathrm{mg}, 0.300 \mathrm{mmol})$ underwent the palladium-catalysed cyclisation. Purification by flash column chromatography [hexane:EtOAc 2:1] afforded 35h (80 mg, 85\%) as a brown solid. Following General Procedure F, propargylic carbonate 34h (76 mg, 0.23 $\mathrm{mmol}$ ) underwent the enantioselective palladium-catalysed cyclisation. Purification by flash column chromatography [hexane:EtOAc $2: 1$ ] afforded $35 \mathrm{~h}(51 \mathrm{mg}, 72 \%) . R_{F}=0.42$ [petrol:EtOAc 2:1]. m.p. $141-146{ }^{\circ} \mathrm{C}$. IR (neat): $2953,2853,1738,1686 \mathrm{~cm}^{-1} .{ }^{1} \mathrm{H}$ NMR $(300$ $\left.\mathrm{MHz}, \mathrm{CDCl}_{3}\right)$ : $\delta 8.01$ (dd, $\left.J=8.4,1.4 \mathrm{~Hz}, 2 \mathrm{H}\right), 7.50-7.43(\mathrm{~m}, 1 \mathrm{H}), 7.38(\mathrm{t}, J=7.3 \mathrm{~Hz}, 2 \mathrm{H})$, $5.49(\mathrm{~s}, 1 \mathrm{H}), 5.41-5.38(\mathrm{~m}, 1 \mathrm{H}), 4.44(\mathrm{~d}, J=8.5 \mathrm{~Hz}, 1 \mathrm{H}), 4.27-4.01(\mathrm{~m}, 2 \mathrm{H}), 3.82(\mathrm{~s}, 3 \mathrm{H})$, $3.80(\mathrm{~s}, 3 \mathrm{H}), 2.62(\mathrm{t}, J=12.5 \mathrm{~Hz}, 2 \mathrm{H}), 1.97(\mathrm{~d}, J=13.6 \mathrm{~Hz}, 1 \mathrm{H}), 1.88-1.64(\mathrm{~m}, 2 \mathrm{H}), 1.44(\mathrm{~s}$, $9 \mathrm{H}), 1.40-1.18(\mathrm{~m}, 2 \mathrm{H}) .{ }^{13} \mathrm{C} \mathrm{NMR}\left(75 \mathrm{MHz}, \mathrm{CDCl}_{3}\right): \delta 168.7,168.7,156.6,154.7,134.7$, 132.6, 131.4, 128.1, 127.9, 117.7, 81.1, 79.4, 70.3, 53.4, 53.3, 43.4 (br), 37.8, 28.4, 28.2. HRMS (ESI) $(\mathrm{m} / \mathrm{z})$ : calcd for $\mathrm{C}_{25} \mathrm{H}_{32} \mathrm{~N}_{2} \mathrm{O}_{7}[\mathrm{M}+\mathrm{H}]+473.2282$; found 473.2266. Chiral HPLC: CHIRALPAK AD-H, $1 \mathrm{~mL} / \mathrm{min}, 95: 5$ hexane: $i-\mathrm{PrOH}, 30^{\circ} \mathrm{C}, t_{\mathrm{A}}$ (major) $=12.7 \mathrm{~min}, t_{\mathrm{B}}($ minor $)=$ $14.7 \mathrm{~min}, 20 \%$ ee. $[\alpha]_{\mathrm{D}}^{20}=+58.3\left(c=0.31, \mathrm{CHCl}_{3}\right)$.

Dimethyl 6-cyclopropyl-5-methylidene-2-phenyl-5,6-dihydro-4H-1,3-oxazine-4,4dicarboxylate (35i). Following General Procedure D, propargylic carbonate 34i (59 mg, 0.3 $\mathrm{mmol}$ ) underwent the palladium-catalysed cyclisation. Purification by flash column chromatography [hexane:EtOAc 7:1] afforded $35 \mathrm{i}(24 \mathrm{mg}, 34 \%)$ as a brown solid. $R_{F}=0.51$ [petrol:EtOAc 3:1]. m.p. 101-104 ${ }^{\circ} \mathrm{C}$. IR (neat): 3008, 2953, 1735, $1643 \mathrm{~cm}^{-1}$. ${ }^{1} \mathrm{H}$ NMR (400 $\left.\mathrm{MHz}, \mathrm{CDCl}_{3}\right)$ : $\delta 8.02(\mathrm{dd}, J=8.5,1.4 \mathrm{~Hz}, 2 \mathrm{H}), 7.50-7.42(\mathrm{~m}, 1 \mathrm{H}), 7.38(\mathrm{t}, J=7.7 \mathrm{~Hz}, 2 \mathrm{H})$, $5.78(\mathrm{~d}, J=1.7 \mathrm{~Hz}, 1 \mathrm{H}), 5.40(\mathrm{~d}, J=1.1 \mathrm{~Hz}, 1 \mathrm{H}), 4.05(\mathrm{dt}, J=8.6,1.4 \mathrm{~Hz}, 1 \mathrm{H}), 3.86(\mathrm{~s}, 3 \mathrm{H})$, $3.80(\mathrm{~s}, 3 \mathrm{H}), 1.29-1.19(\mathrm{~m}, 1 \mathrm{H}), 0.81-0.72(\mathrm{~m}, 2 \mathrm{H}), 0.60$ (ddd, $J=9.7,4.8,1.2 \mathrm{~Hz}, 1 \mathrm{H})$, $0.53-0.46(\mathrm{~m}, 1 \mathrm{H}) .{ }^{13} \mathrm{C}$ NMR $\left(100 \mathrm{MHz}, \mathrm{CDCl}_{3}\right): \delta 169.1,168.9,157.8,137.7,132.9,131.2$, 128.0, 128.0, 115.2, 80.0, 71.3, 53.4, 53.2, 12.5, 3.3, 2.8. HRMS (ESI) ( $\mathrm{m} / \mathrm{z})$ : calcd for $\mathrm{C}_{18} \mathrm{H}_{19} \mathrm{NO}_{5}[\mathrm{M}+\mathrm{H}]+330.1336$; found 330.1325 . 
Dimethyl 5-methylidene-2-phenyl-6-(propan-2-yl)-5,6-dihydro-4H-1,3-oxazine-4,4dicarboxylate (35j). Following General Procedure D, propargylic carbonate $34 \mathbf{j}(59.5 \mathrm{mg}$, $0.30 \mathrm{mmol}$ ) underwent the palladium-catalysed cyclisation. Purification by flash column chromatography [hexane:EtOAc 5:1] afforded $35 \mathrm{j}$ (17 $\mathrm{mg}, 32 \%)$ as a brown solid. $R_{F}=0.51$ [petrol:EtOAc 3:1]. m.p. $124-127^{\circ} \mathrm{C}$. IR (neat): 2953, 2873, 1750, $1645 \mathrm{~cm}^{-1}$. ${ }^{1} \mathrm{H}$ NMR $(400$ $\mathrm{MHz}, \mathrm{CDCl}_{3}$ ): $\delta 8.04$ (dd, $\left.J=8.5,1.4 \mathrm{~Hz}, 2 \mathrm{H}\right), 7.47$ (tt, $\left.J=7.4,1.4 \mathrm{~Hz}, 1 \mathrm{H}\right), 7.39$ (t, $J=7.3$ $\mathrm{Hz}, 2 \mathrm{H}), 5.46(\mathrm{~s}, 1 \mathrm{H}), 5.43(\mathrm{~d}, J=1.3 \mathrm{~Hz}, 1 \mathrm{H}), 4.42(\mathrm{dt}, J=7.7,1.1 \mathrm{~Hz}, 1 \mathrm{H}), 3.84(\mathrm{~s}, 3 \mathrm{H})$, $3.81(\mathrm{~s}, 3 \mathrm{H}), 2.13-1.99(\mathrm{~m}, 1 \mathrm{H}), 1.09(\mathrm{~d}, J=6.5 \mathrm{~Hz}, 3 \mathrm{H}), 1.04(\mathrm{~d}, J=6.7 \mathrm{~Hz}, 3 \mathrm{H}) .{ }^{13} \mathrm{C}$ NMR $\left(100 \mathrm{MHz}, \mathrm{CDCl}_{3}\right): \delta 168.9,168.8,157.3,135.8,132.8,131.3,128.1,128.0,116.9,82.4$, 70.7, 53.4, 53.3, 29.8, 19.5, 18.2. HRMS (ESI) $(\mathrm{m} / \mathrm{z})$ : calcd for $\mathrm{C}_{18} \mathrm{H}_{21} \mathrm{NO}_{5}[\mathrm{M}+\mathrm{H}]+332.1492$; found 332.1495 .

\section{Dimethyl 6-tert-butyl-5-methylidene-2-phenyl-5,6-dihydro-4 $H$-1,3-oxazine-4,4-} dicarboxylate (35k). Following General Procedure F, propargylic carbonate 34k (34 mg, $0.23 \mathrm{mmol}$ ) underwent the enantioselective palladium-catalysed cyclisation. Purification by flash column chromatography [hexane:EtOAc 7:1] afforded $\mathbf{3 5 k}(8 \mathrm{mg}, 16 \%)$ as a brown solid. $R_{F}=0.56$ [petrol:EtOAc 3:1]. m.p. $132-134^{\circ} \mathrm{C}$. IR (neat): 3026, 2950, 1729, $1645 \mathrm{~cm}^{-}$ 1. ${ }^{1} \mathrm{H}$ NMR $\left(400 \mathrm{MHz}, \mathrm{CDCl}_{3}\right): \delta 8.06(\mathrm{~d}, J=7.0 \mathrm{~Hz}, 2 \mathrm{H}), 7.47(\mathrm{tt}, J=7.2,1.4 \mathrm{~Hz}, 1 \mathrm{H}), 7.40$ $(\mathrm{t}, J=7.3 \mathrm{~Hz}, 2 \mathrm{H}), 5.57(\mathrm{~s}, 1 \mathrm{H}), 5.51(\mathrm{~d}, J=1.7 \mathrm{~Hz}, 1 \mathrm{H}), 4.49(\mathrm{t}, J=1.1 \mathrm{~Hz}, 1 \mathrm{H}), 3.85(\mathrm{~s}$, $3 \mathrm{H}), 3.77(\mathrm{~s}, 3 \mathrm{H}), 1.04(\mathrm{~s}, 9 \mathrm{H}) .{ }^{13} \mathrm{C}$ NMR $\left(100 \mathrm{MHz}, \mathrm{CDCl}_{3}\right): \delta$ 169.5, 169.0, 157.2, 134.1, 133.2, 131.2, 128.1, 128.0, 119.7, 84.5, 71.2, 53.5, 53.3, 29.7, 26.7. HRMS (ESI) $(\mathrm{m} / \mathrm{z})$ : calcd for $\mathrm{C}_{19} \mathrm{H}_{23} \mathrm{NO}_{5}[\mathrm{M}+\mathrm{H}]+346.1649$; found 346.1635. Chiral HPLC: CHIRALPAK AD-H, 1 $\mathrm{mL} / \mathrm{min}, 90: 10$ hexane: $-\mathrm{PrOH}, 30^{\circ} \mathrm{C}, t_{\mathrm{A}}$ (major) $=5.1 \mathrm{~min}, t_{\mathrm{B}}$ (minor) $=6.5 \mathrm{~min}, 48 \%$ ee. $[\alpha]_{D}^{20}=+92.6\left(c=0.03, \mathrm{CHCl}_{3}\right)$.

\section{Dimethyl 5-methylidene-2,6-diphenyl-5,6-dihydro-4H-1,3-oxazine-4,4-dicarboxylate} (35n). Following General Procedure E, propargylic carbonate $34 \mathrm{n}$ (70 mg, $0.30 \mathrm{mmol})$ underwent the palladium-catalysed cyclisation. The ratio of 35n:36n in the crude product mixture was 8.9:1. Purification by flash column chromatography [hexane:EtOAc 9:1] afforded an inseparable $8.5: 1$ mixture of $35 \mathrm{n}: 36 \mathrm{n}(71 \mathrm{mg})$, corresponding to pure $35 \mathrm{n}$ (63.5 $\mathrm{mg}$, $87 \%$ ). Following General Procedure F, propargylic carbonate 34n (52 mg, $0.23 \mathrm{mmol}$ ) underwent the enantioselective palladium-catalysed cyclisation. Purification by flash column

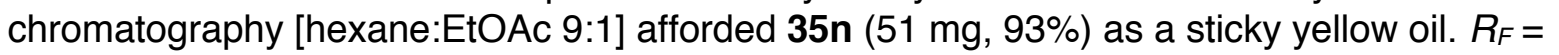
0.54 [petrol:EtOAc 2:1]. IR (neat): 2951, 1735, $1646 \mathrm{~cm}^{-1} .{ }^{1} \mathrm{H} \mathrm{NMR}\left(400 \mathrm{MHz}, \mathrm{CDCl}_{3}\right): \delta$ $8.07(\mathrm{dd}, J=8.5,1.4 \mathrm{~Hz}, 2 \mathrm{H}), 7.48(\mathrm{tt}, J=7.2,1.4 \mathrm{~Hz}, 1 \mathrm{H}), 7.44-7.36(\mathrm{~m}, 7 \mathrm{H}), 5.91(\mathrm{t}, J=$ $1.5 \mathrm{~Hz}, 1 \mathrm{H}), 5.37(\mathrm{~d}, J=1.3 \mathrm{~Hz}, 1 \mathrm{H}), 4.90(\mathrm{~d}, J=1.7 \mathrm{~Hz}, 1 \mathrm{H}), 3.88(\mathrm{~s}, 3 \mathrm{H}), 3.79(\mathrm{~s}, 3 \mathrm{H}) .{ }^{13} \mathrm{C}$ NMR $\left(100 \mathrm{MHz}, \mathrm{CDCl}_{3}\right): \delta 169.0,168.6,157.7,138.6,136.2,132.5,131.4,128.7,128.5$, 128.1, 128.1, 127.5, 117.7, 78.2, 71.2, 53.5, 53.1. HRMS (ESI) $(\mathrm{m} / \mathrm{z})$ : calcd for $\mathrm{C}_{21} \mathrm{H}_{19} \mathrm{NO}_{5}$ $[\mathrm{M}+\mathrm{H}]^{+}$366.1336; found 366.1337. Chiral HPLC: CHIRALPAK AD-H, $1 \mathrm{~mL} / \mathrm{min}, 90: 10$ hexane: $i-\mathrm{PrOH}, 30^{\circ} \mathrm{C}, t_{\mathrm{A}}$ (minor) $=7.1 \mathrm{~min}, t_{\mathrm{B}}$ (major) $=7.9 \mathrm{~min}, 33 \%$ ee. $[\mathrm{a}]_{\mathrm{D}^{20}}=+20.1(\mathrm{c}=$ $\left.0.37, \mathrm{CHCl}_{3}\right)$.

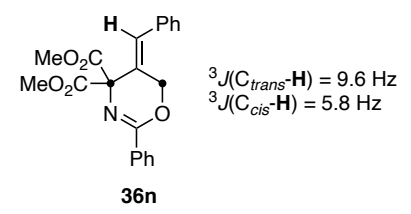

(5Z)-Dimethyl 5-benzylidene-2-phenyl-5,6-dihydro-4H-1,3-oxazine-4,4-dicarboxylate (36n). A tube was charged with amide $25 a(50 \mathrm{mg}, 0.20 \mathrm{mmol})$, propargylic electrophile $34 \mathrm{n}$ (70 mg, $0.30 \mathrm{mmol}), \mathrm{Pd}_{2} \mathrm{dba}_{3}(9.2 \mathrm{mg}, 0.010 \mathrm{mmol}$ ) and DPEphos (11 mg, $0.020 \mathrm{mmol}$ ). $\operatorname{MeCN}\left(2 \mathrm{~mL}\right.$ ) was added. The tube was sealed and the mixture heated at $80^{\circ} \mathrm{C}$ for $15 \mathrm{~h}$. 
The solution was allowed to cool to room temperature and concentrated in vacuo. The ratio of $35 n: 36 n$ in the crude product mixture was 1:3.0. Purification by flash column chromatography [hexane:EtOAc 9:1] afforded an inseparable 1:3.3 mixture of 35n:36n (71.5 $\mathrm{mg})$ as a clear oil, corresponding to pure $36 \mathrm{n}(55 \mathrm{mg}, 75 \%) . R_{F}=0.54$ [petrol:EtOAc 2:1]. IR (neat): 3029, 2952, 1733, $1646 \mathrm{~cm}^{-1}$. ${ }^{1} \mathrm{H}$ NMR (400 MHz, $\left.\mathrm{CDCl}_{3}\right): \delta 8.00$ (d, J=7.1 Hz, 2H), 7.49-7.29 (m, 6H), $7.21(\mathrm{~d}, J=7.1 \mathrm{~Hz}, 2 \mathrm{H}), 6.84(\mathrm{~s}, 1 \mathrm{H}), 5.08(\mathrm{~d}, J=1.3 \mathrm{~Hz}, 2 \mathrm{H}), 3.89$ (s, $6 \mathrm{H}) .{ }^{13} \mathrm{C} \mathrm{NMR}\left(100 \mathrm{MHz}, \mathrm{CDCl}_{3}\right): \delta 168.9,157.6,134.8,132.5,131.3,130.2,128.9,128.4$, 128.0, 127.9, 127.9, 127.6, 70.7, 63.3, 53.3. HRMS (ESI) $(\mathrm{m} / \mathrm{z})$ : calcd for $\mathrm{C}_{21} \mathrm{H}_{19} \mathrm{NO}_{5}[\mathrm{M}+\mathrm{H}]^{+}$ 366.1336; found 366.1338. A proton-selective HSQMBC NMR experiment was used to establish the alkene geometry in $36 \mathrm{n}$ by virtue of trans $\left.{ }^{3} \mathrm{~J}^{13} \mathrm{C}-{ }^{1} \mathrm{H}\right)$ alkene coupling constants being larger than cis. ${ }^{35}$

Dimethyl 6-(4-methoxyphenyl)-5-methylidene-2-phenyl-5,6-dihydro-4 $H$-1,3-oxazine-4,4dicarboxylate (35o). Following General Procedure E, propargylic carbonate 340 (79 mg, $0.30 \mathrm{mmol}$ ) underwent the palladium-catalysed cyclisation. The ratio of $350: 360$ in the crude product mixture was 8.9:1. Purification by flash column chromatography [hexane:EtOAc 6:1] afforded an inseparable 9.5:1 mixture of 35o:36o (65 mg), corresponding to pure 35o (59 $\mathrm{mg}, 75 \%$ ). Following General Procedure F, propargylic carbonate 340 (59 mg, $0.23 \mathrm{mmol})$ underwent the enantioselective palladium-catalysed cyclisation. Purification by flash column chromatography [hexane:EtOAc $6: 1$ ] afforded $350(48 \mathrm{mg}, 81 \%)$ as a pale yellow oil. $R_{F}=$ 0.58 [petrol:EtOAc 2:1]. IR (neat): 2953, 1735, 1646, 1612, $1513 \mathrm{~cm}^{-1} .{ }^{1} \mathrm{H}$ NMR $(400 \mathrm{MHz}$, $\left.\mathrm{CDCl}_{3}\right): \delta 8.05(\mathrm{dd}, J=8.5,1.4 \mathrm{~Hz}, 2 \mathrm{H}), 7.46(\mathrm{tt}, J=7.3,1.4 \mathrm{~Hz}, 1 \mathrm{H}), 7.38(\mathrm{t}, J=7.4 \mathrm{~Hz}$, $2 \mathrm{H}), 7.33(\mathrm{~d}, J=8.4 \mathrm{~Hz}, 2 \mathrm{H}), 6.95(\mathrm{~d}, J=8.9 \mathrm{~Hz}, 2 \mathrm{H}), 5.86(\mathrm{~s}, 1 \mathrm{H}), 5.36(\mathrm{~d}, J=1.6 \mathrm{~Hz}, 1 \mathrm{H})$, $4.90(\mathrm{~d}, J=2.0 \mathrm{~Hz}, 1 \mathrm{H}), 3.87(\mathrm{~s}, 3 \mathrm{H}), 3.84(\mathrm{~s}, 3 \mathrm{H}), 3.81(\mathrm{~s}, 3 \mathrm{H}) .{ }^{13} \mathrm{C} \mathrm{NMR}\left(100 \mathrm{MHz}, \mathrm{CDCl}_{3}\right)$ : $\delta 169.0,168.7,159.9,157.9,138.9,132.6,131.3,129.0,128.2,128.1,128.0,117.6,113.9$, 78.0. 71.3, 55.3, 53.5, 53.1. HRMS (ESI) $(\mathrm{m} / \mathrm{z})$ : calcd for $\mathrm{C}_{22} \mathrm{H}_{21} \mathrm{NO}_{6}[\mathrm{M}+\mathrm{H}]^{+} 396.1442$; found 396.1440. Chiral HPLC: CHIRALPAK AD-H, $1 \mathrm{~mL} / \mathrm{min}, 90: 10$ hexane:i-PrOH, $30^{\circ} \mathrm{C}, t_{\mathrm{A}}$ $($ minor $)=9.2 \mathrm{~min}, t_{\mathrm{B}}($ major $)=11.5 \mathrm{~min}, 19 \%$ ee. $[\alpha]_{\mathrm{D}}^{20}=+29.8\left(c=0.34, \mathrm{CHCl}_{3}\right)$.

Dimethyl 6-(3,4-dimethoxyphenyl)-5-methylidene-2-phenyl-5,6-dihydro-4H-1,3-oxazine4,4-dicarboxylate (35p). Following General Procedure E, propargylic carbonate $34 p$ (88 $\mathrm{mg}, 0.30 \mathrm{mmol}$ ) underwent the palladium-catalysed cyclisation. The ratio of 35p:36p in the crude product mixture was 4.3:1. Purification by flash column chromatography [hexane:EtOAc 4:1] afforded an inseparable 4.9:1 mixture of 35p:36p (70 mg),

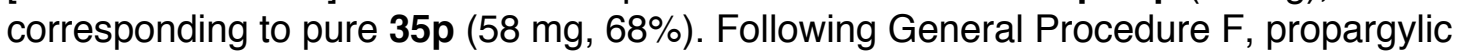
carbonate $34 \mathrm{p}$ (66 $\mathrm{mg}, 0.23 \mathrm{mmol}$ ) underwent the enantioselective palladium-catalysed cyclisation. Purification by flash column chromatography [hexane:EtOAc 4:1] afforded 35p $(57 \mathrm{mg}, 89 \%)$ as a sticky pale yellow oil. $R_{F}=0.31$ [petrol:EtOAc 2:1]. IR (neat): 2954, 1735, 1646, $1512 \mathrm{~cm}^{-1} .{ }^{1} \mathrm{H}$ NMR $\left(400 \mathrm{MHz}, \mathrm{CDCl}_{3}\right): \delta 8.05$ (dd, $\left.J=8.5,1.4 \mathrm{~Hz}, 2 \mathrm{H}\right), 7.46(\mathrm{tt}, J=$ 7.2, $1.4 \mathrm{~Hz}, 1 \mathrm{H}), 7.38(\mathrm{t}, J=7.4 \mathrm{~Hz}, 2 \mathrm{H}), 6.97(\mathrm{dd}, J=8.4,1.8 \mathrm{~Hz}, 1 \mathrm{H}), 6.91(\mathrm{~d}, J=8.3 \mathrm{~Hz}$, $1 \mathrm{H}), 6.89(\mathrm{~d}, J=2.0 \mathrm{~Hz}, 1 \mathrm{H}), 5.85(\mathrm{~s}, 1 \mathrm{H}), 5.36(\mathrm{~d}, J=1.3 \mathrm{~Hz}, 1 \mathrm{H}), 4.93(\mathrm{~d}, J=1.8 \mathrm{~Hz}, 1 \mathrm{H})$, 3.91 (s, 3H), 3.86 (s, 3H), $3.86(\mathrm{~s}, 3 \mathrm{H}), 3.82(\mathrm{~s}, 3 \mathrm{H}) .{ }^{13} \mathrm{C} \mathrm{NMR}\left(100 \mathrm{MHz}, \mathrm{CDCl}_{3}\right): \delta$ 169.0, 168.7, 157.9, 149.3, 149.0, 138.7, 132.5, 131.4, 128.6, 128.1, 128.1, 120.4, 117.6, 110.9, 110.5, 78.2, 71.3, 56.0, 55.9, 53.5, 53.1. HRMS (ESI) $(\mathrm{m} / \mathrm{z})$ : calcd for $\mathrm{C}_{23} \mathrm{H}_{23} \mathrm{NO}_{7}[\mathrm{M}+\mathrm{H}]^{+}$ 426.1547; found 426.1543. Chiral HPLC: CHIRALPAK AD-H, $1 \mathrm{~mL} / \mathrm{min}, 90: 10$ hexane:i$\mathrm{PrOH}, 30{ }^{\circ} \mathrm{C}, t_{\mathrm{A}}($ minor $)=12.1 \mathrm{~min}, t_{\mathrm{B}}$ (major $)=13.3 \mathrm{~min}, 19 \%$ ee. $[\alpha]_{\mathrm{D}^{20}}=+13.2(c=0.46$, $\left.\mathrm{CHCl}_{3}\right)$.

Dimethyl 5-methylidene-6-(4-methylphenyl)-2-phenyl-5,6-dihydro-4 H-1,3-oxazine-4,4dicarboxylate (35q). Following General Procedure E, propargylic carbonate $\mathbf{3 4 q}(74 \mathrm{mg}$, $0.30 \mathrm{mmol}$ ) underwent the palladium-catalysed cyclisation. The ratio of $\mathbf{3 5 q}: \mathbf{3 6 q}$ in the crude product mixture was 9.4:1. Purification by flash column chromatography [hexane:EtOAc 9:1] 
afforded an inseparable 9.8:1 mixture of 35q:36q (65 mg), corresponding to pure $\mathbf{3 5 q}$ (59 $\mathrm{mg}, 78 \%$ ). Following General Procedure F, propargylic carbonate 34q (55 mg, $0.22 \mathrm{mmol}$ ) underwent the enantioselective palladium-catalysed cyclisation. Purification by flash column chromatography [hexane:EtOAc 9:1] afforded $\mathbf{3 5 q}(48.5 \mathrm{mg}, 85 \%)$ as a sticky yellow oil. $R_{F}$ $=0.67$ [petrol:EtOAc 2:1]. IR (neat): 2952, 1735, $1646 \mathrm{~cm}^{-1} .{ }^{1} \mathrm{H} \mathrm{NMR}\left(400 \mathrm{MHz}, \mathrm{CDCl}_{3}\right): \delta$ $8.06(\mathrm{dd}, J=8.5,1.4 \mathrm{~Hz}, 2 \mathrm{H}), 7.47(\mathrm{tt}, J=7.4,1.3 \mathrm{~Hz}, 1 \mathrm{H}), 7.38(\mathrm{t}, J=7.4 \mathrm{~Hz}, 2 \mathrm{H}), 7.30$ (d, $J=8.2 \mathrm{~Hz}, 2 \mathrm{H}), 7.23(\mathrm{~d}, J=7.8 \mathrm{~Hz}, 2 \mathrm{H}), 5.87(\mathrm{~s}, 1 \mathrm{H}), 5.36(\mathrm{~d}, J=1.3 \mathrm{~Hz}, 1 \mathrm{H}), 4.90(\mathrm{~d}, J=$ $2.2 \mathrm{~Hz}, 1 \mathrm{H}), 3.87(\mathrm{~s}, 3 \mathrm{H}), 3.80(\mathrm{~s}, 3 \mathrm{H}), 2.39(\mathrm{~s}, 3 \mathrm{H}) .{ }^{13} \mathrm{C} \mathrm{NMR}\left(100 \mathrm{MHz}, \mathrm{CDCl}_{3}\right): \delta$ 169.0, 168.7, 157.9, 138.7, 138.6, 133.2, 132.6, 131.3, 129.2, 128.1, 128.1, 127.6, 117.6, 78.2, 71.3, 53.5, 53.1, 21.2. HRMS (ESI) $(\mathrm{m} / \mathrm{z})$ : calcd for $\mathrm{C}_{22} \mathrm{H}_{21} \mathrm{NO}_{5}[\mathrm{M}+\mathrm{H}]+380.1492$; found 380.1482. Chiral HPLC: CHIRALPAK AD-H, $1 \mathrm{~mL} / \mathrm{min}, 90: 10$ hexane:i-PrOH, $30{ }^{\circ} \mathrm{C}, t_{\mathrm{A}}$ $($ minor $)=7.3 \mathrm{~min}, t_{\mathrm{B}}($ major $)=9.6 \mathrm{~min}, 29 \%$ ee. $[\alpha]_{\mathrm{D}}^{20}=+11.8\left(c=0.38, \mathrm{CHCl}_{3}\right)$.

Dimethyl 5-methylidene-6-(2-methylphenyl)-2-phenyl-5,6-dihydro-4H-1,3-oxazine-4,4dicarboxylate (35r). Following General Procedure E, propargylic carbonate $34 \mathrm{r}(74 \mathrm{mg}$, $0.30 \mathrm{mmol}$ ) underwent the palladium-catalysed cyclisation. The ratio of $35 \mathrm{r}: 36 \mathrm{r}$ in the crude product mixture was 3.4:1. Purification by flash column chromatography [hexane:EtOAc $5: 1$ ] afforded an inseparable 3.4:1 mixture of $35 \mathrm{r}: 36 \mathrm{r}(63 \mathrm{mg})$, corresponding to pure $35 \mathrm{r}(49 \mathrm{mg}$, $65 \%$ ). Following General Procedure F, propargylic carbonate $34 \mathrm{r}$ (55 mg, $0.23 \mathrm{mmol}$ ) underwent the enantioselective palladium-catalysed cyclisation. Purification by flash column chromatography [hexane:EtOAc $6: 1$ ] afforded $35 \mathrm{r}(49 \mathrm{mg}, 86 \%)$ as a sticky yellow oil. $R_{F}=$ 0.47 [petrol:EtOAc 2:1]. IR (neat): 2952, $1735,1646 \mathrm{~cm}^{-1}$. ${ }^{1} \mathrm{H} \mathrm{NMR}\left(400 \mathrm{MHz}, \mathrm{CDCl}_{3}\right): \delta$ $8.08(\mathrm{~d}, J=7.1 \mathrm{~Hz}, 2 \mathrm{H}), 7.51-7.45(\mathrm{~m}, 2 \mathrm{H}), 7.40(\mathrm{t}, J=7.4 \mathrm{~Hz}, 2 \mathrm{H}), 7.34-7.28(\mathrm{~m}, 2 \mathrm{H}), 7.27-$ $7.22(\mathrm{~m}, 1 \mathrm{H}), 6.06(\mathrm{~s}, 1 \mathrm{H}), 5.29(\mathrm{~s}, 1 \mathrm{H}), 4.75(\mathrm{~d}, J=1.7 \mathrm{~Hz}, 1 \mathrm{H}), 3.89(\mathrm{~s}, 3 \mathrm{H}), 3.87(\mathrm{~s}, 3 \mathrm{H})$, 2.37 (s, 3H). ${ }^{13} \mathrm{C}$ NMR $\left(100 \mathrm{MHz}, \mathrm{CDCl}_{3}\right): \delta 169.2,168.8,158.1,137.6,136.3,134.3,132.5$, $131.4,130.4,128.5,128.1,128.1,127.0,126.3,116.8,75.5,71.7,53.4,53.2,18.8$. HRMS (ESI) $(\mathrm{m} / \mathrm{z})$ : calcd for $\mathrm{C}_{22} \mathrm{H}_{21} \mathrm{NO}_{5}[\mathrm{M}+\mathrm{Na}]^{+}$402.1312; found 402.1294. Chiral HPLC: CHIRALPAK AD-H, $1 \mathrm{~mL} / \mathrm{min}, 95: 5$ hexane: $-\mathrm{PrOH}, 30^{\circ} \mathrm{C}, t_{\mathrm{A}}$ (minor) $=6.8 \mathrm{~min}, t_{\mathrm{B}}$ (major) $=$ $7.4 \min , 51 \%$ ee. $[\alpha]_{D}^{20}=-23.9\left(c=0.36, \mathrm{CHCl}_{3}\right)$.

Dimethyl 6-(4-(methoxycarbonyl)phenyl)-5-methylidene-2-phenyl-5,6-dihydro-4H-1,3oxazine-4,4-dicarboxylate (35s). Following General Procedure E, propargylic carbonate $34 \mathrm{~s}$ (87 $\mathrm{mg}, 0.30 \mathrm{mmol}$ ) underwent the palladium-catalysed cyclisation. The ratio of $35 \mathrm{~s}: 36 \mathrm{~s}$ in the crude product mixture was 3.7:1. Purification by flash column chromatography [hexane:EtOAc 4:1] afforded an inseparable 3.7:1 mixture of $35 \mathrm{~s}: 36 \mathrm{~s}(77 \mathrm{mg})$, corresponding to pure 35s (61 mg, 72\%). Following General Procedure F, propargylic carbonate $34 \mathrm{~s}$ ( $65 \mathrm{mg}, 0.23 \mathrm{mmol}$ ) underwent the enantioselective palladium-catalysed cyclisation. Purification by flash column chromatography [hexane:EtOAc 4:1] afforded 35s (64 mg, quant.) as a pale yellow oil. $R_{F}=0.52$ [petrol:EtOAc 2:1]. IR (neat): 2954, 1720, $1646 \mathrm{~cm}^{-1}$. ${ }^{1} \mathrm{H}$ NMR $\left(400 \mathrm{MHz}, \mathrm{CDCl}_{3}\right): \delta 8.10(\mathrm{~d}, J=8.7 \mathrm{~Hz}, 2 \mathrm{H}), 8.05(\mathrm{~d}, J=7.1 \mathrm{~Hz}, 2 \mathrm{H})$, 7.52-7.45 (m, 3H), 7.39 (t, $J=7.4 \mathrm{~Hz}, 2 \mathrm{H}), 5.96(\mathrm{~s}, 1 \mathrm{H}), 5.38(\mathrm{~s}, 1 \mathrm{H}), 4.85(\mathrm{~d}, J=1.0 \mathrm{~Hz}$, $1 \mathrm{H}), 3.93(\mathrm{~s}, 3 \mathrm{H}), 3.87(\mathrm{~s}, 3 \mathrm{H}), 3.78(\mathrm{~s}, 3 \mathrm{H}) .{ }^{13} \mathrm{C} \mathrm{NMR}\left(100 \mathrm{MHz}, \mathrm{CDCl}_{3}\right): \delta 168.8,168.4$, 166.5, 157.4, 141.1, 138.1, 132.2, 131.5, 130.5, 129.8, 128.1, 128.0, 127.5, 117.8, 77.6, 71.1, 53.5, 53.2, 52.2. HRMS (ESI) $(\mathrm{m} / \mathrm{z})$ : calcd for $\mathrm{C}_{23} \mathrm{H}_{21} \mathrm{NO}_{7}[\mathrm{M}+\mathrm{H}]+424.1391$; found 424.1384. Chiral HPLC: CHIRALPAK AD-H, $1 \mathrm{~mL} / \mathrm{min}, 90: 10$ hexane:i-PrOH, $30^{\circ} \mathrm{C}, t_{\mathrm{A}}$ $($ minor $)=15.7 \mathrm{~min}, t_{\mathrm{B}}($ major $)=18.7 \mathrm{~min}, 32 \%$ ee. $[\alpha]_{\mathrm{D}}^{20}=+9.7\left(c=0.46, \mathrm{CHCl}_{3}\right)$.

Dimethyl 6-(4-chlorophenyl)-5-methylidene-2-phenyl-5,6-dihydro-4 $\mathrm{H}-1,3-0 x a z i n e-4,4-$ dicarboxylate (35t). Following General Procedure E, propargylic carbonate $34 \mathrm{t}(80 \mathrm{mg}$, $0.30 \mathrm{mmol}$ ) underwent the palladium-catalysed cyclisation. The ratio of $35 \mathrm{t}: 36 \mathrm{t}$ in the crude product mixture was 5.4:1. Purification by flash column chromatography [hexane:EtOAc 9:1] afforded an inseparable 5.6:1 mixture of 35t:36t $(75 \mathrm{mg})$, corresponding to pure $35 \mathrm{t}(64 \mathrm{mg}$, 
$80 \%)$. Following General Procedure F, propargylic carbonate 34t $(60 \mathrm{mg}, 0.23 \mathrm{mmol})$ underwent the enantioselective palladium-catalysed cyclisation. Purification by flash column chromatography [hexane:EtOAc 9:1] afforded $35 \mathrm{t}(52.5 \mathrm{mg}, 88 \%)$ as a sticky yellow oil. $R_{F}=$ 0.54 [petrol:EtOAc 2:1]. IR (neat): 2952, $1735,1646 \mathrm{~cm}^{-1} .{ }^{1} \mathrm{H}$ NMR $\left(400 \mathrm{MHz}, \mathrm{CDCl}_{3}\right): \delta$ $8.04(\mathrm{dd}, J=8.4,1.3 \mathrm{~Hz}, 2 \mathrm{H}), 7.48(\mathrm{tt}, J=7.4,1.3 \mathrm{~Hz}, 1 \mathrm{H}), 7.43-7.32(\mathrm{~m}, 6 \mathrm{H}), 5.89(\mathrm{~s}, 1 \mathrm{H})$, $5.38(\mathrm{~s}, 1 \mathrm{H}), 4.88(\mathrm{dd}, J=1.7,0.7 \mathrm{~Hz}, 1 \mathrm{H}), 3.87(\mathrm{~s}, 3 \mathrm{H}), 3.80(\mathrm{~s}, 3 \mathrm{H}) .{ }^{13} \mathrm{C} \mathrm{NMR}(100 \mathrm{MHz}$, $\left.\mathrm{CDCl}_{3}\right): \delta 168.9,168.5,157.5,138.3,134.7,134.6,132.3,131.5,129.0,128.8,128.1,128.0$, 117.8, 77.5, 71.1, 53.5, 53.2. HRMS (ESI) $(\mathrm{m} / \mathrm{z})$ : calcd for $\mathrm{C}_{21} \mathrm{H}_{18} \mathrm{NO}_{5}{ }^{35} \mathrm{Cl}[\mathrm{M}+\mathrm{Na}]^{+}$422.0766; found 422.0766. Chiral HPLC: CHIRALPAK AD-H, $1 \mathrm{~mL} / \mathrm{min}, 90: 10$ hexane: $i-\mathrm{PrOH}, 30^{\circ} \mathrm{C}, t_{\mathrm{A}}$ $($ minor $)=7.7 \mathrm{~min}, t_{\mathrm{B}}($ major $)=9.2 \mathrm{~min}, 34 \%$ ee. $[\alpha]_{\mathrm{D}}{ }^{20}=+23.6\left(c=0.38, \mathrm{CHCl}_{3}\right)$.

\section{Dimethyl 6-(4-fluorophenyl)-5-methylidene-2-phenyl-5,6-dihydro-4H-1,3-oxazine-4,4- dicarboxylate (35u). Following General Procedure E, propargylic carbonate $34 \mathrm{u}$ (75 mg,} $0.30 \mathrm{mmol}$ ) underwent the palladium-catalysed cyclisation. The ratio of $35 \mathrm{u}: 36 \mathrm{u}$ in the crude product mixture was $8.0: 1$. Purification by flash column chromatography [hexane:EtOAc 5:1] afforded an inseparable 8.0:1 mixture of $35 \mathrm{u}: 36 \mathrm{u}(69.5 \mathrm{mg})$, corresponding to pure $35 \mathrm{u}$ (62 $\mathrm{mg}, 81 \%)$. Following General Procedure F, propargylic carbonate $34 \mathrm{u}$ (56 mg, $0.23 \mathrm{mmol}$ ) underwent the enantioselective palladium-catalysed cyclisation. Purification by flash column chromatography [hexane:EtOAc 6:1] afforded $35 \mathrm{u}(53 \mathrm{mg}, 92 \%)$ as a pale yellow solid. $R_{F}=$ 0.48 [petrol:EtOAc 2:1]. m.p. $131-133^{\circ} \mathrm{C}$. IR (neat): 2950, 1746, 1730, 1645, $1510 \mathrm{~cm}^{-1} .{ }^{1} \mathrm{H}$ $\operatorname{NMR}\left(400 \mathrm{MHz}, \mathrm{CDCl}_{3}\right): \delta 8.04$ (dd, $\left.J=8.5,1.4 \mathrm{~Hz}, 2 \mathrm{H}\right), 7.47$ (tt, $J=7.3,1.3 \mathrm{~Hz}, 1 \mathrm{H}$ ), $7.42-$ $7.36(\mathrm{~m}, 4 \mathrm{H}), 7.12(\mathrm{t}, J=8.7 \mathrm{~Hz}, 2 \mathrm{H}), 5.89(\mathrm{~s}, 1 \mathrm{H}), 5.38(\mathrm{~s}, 1 \mathrm{H}), 4.87$ (dd, $J=1.7,0.6 \mathrm{~Hz}$, $1 \mathrm{H}), 3.87(\mathrm{~s}, 3 \mathrm{H}), 3.81(\mathrm{~s}, 3 \mathrm{H}) \cdot{ }^{13} \mathrm{C}$ NMR $\left(100 \mathrm{MHz}, \mathrm{CDCl}_{3}\right): \delta 168.9,168.5,162.8(\mathrm{~d}, J=$ $247.7 \mathrm{~Hz}), 157.6,138.6,132.4,132.0(\mathrm{~d}, J=3.1 \mathrm{~Hz}), 131.5,129.4$ (d, $J=8.2 \mathrm{~Hz}), 128.1$, 128.0, 117.7, $115.6(\mathrm{~d}, J=21.6 \mathrm{~Hz}), 77.6,71.2,53.5,53.2 .{ }^{19} \mathrm{~F}\left\{{ }^{1} \mathrm{H}\right\} \mathrm{NMR}\left(376 \mathrm{MHz}, \mathrm{CDCl}_{3}\right)$ : $\delta$-112.8. HRMS (ESI) $(\mathrm{m} / \mathrm{z})$ : calcd for $\mathrm{C}_{21} \mathrm{H}_{18} \mathrm{NO}_{5} \mathrm{~F}[\mathrm{M}+\mathrm{H}]+384.1242$; found 384.1227. Chiral HPLC: CHIRALPAK AD-H, $1 \mathrm{~mL} / \mathrm{min}, 90: 10$ hexane: $i-\mathrm{PrOH}, 30^{\circ} \mathrm{C}, t_{\mathrm{A}}$ (minor) $=7.4 \mathrm{~min}, t_{\mathrm{B}}$ (major) $=8.0 \mathrm{~min}, 33 \%$ ee. $[\alpha]_{\mathrm{D}}^{20}=+16.7\left(c=0.42, \mathrm{CHCl}_{3}\right)$.

Acknowledgments. We gratefully acknowledge Dr Nathan Halcovitch for X-ray analysis, Dr David Rochester for mass spectrometric analysis and HPLC support, as well as Dr Geoffrey Akien for help with NMR analysis.

\section{References and notes.}

(1) (a) Vitaku, E.; Smith, D. T.; Njardarson, J. T. J. Med. Chem. 2014, 57, 10257. (b) Delost, M. D.; Smith, D. T.; Anderson, B. J.; Njardarson, J. T. J. Med. Chem. 2018, 61, 10996. (c) Pitt, W. R.; Parry, D. M.; Perry, B. G.; Groom, C. R. J. Med. Chem. 2009, 52, 2952. (d) Taylor, R. D.; MacCoss, M.; Lawson, A. D. G. J. Med. Chem. 2014, 57, 5845.

(2) (a) Taylor, A. P.; Robinson, R. P.; Fobian, Y. M.; Blakemore, D. C.; Jones, L. H.; Fadeyi, O. Org. Biomol. Chem. 2016, 14, 6611. (b) Cabrele, C.; Reiser, O. J. Org. Chem. 2016, 81, 10109.

(3) (a) Brown, D. G.; Boström, J. J. Med. Chem. 2016, 59, 4443. (b) Walters, W. P.; Green, J.; Weiss, J. R.; Murcko, M. A. J. Med. Chem. 2011, 54, 6405.

(4) (a) Lovering, F.; Bikker, J.; Humblet, C. J. Med. Chem. 2009, 52, 6752. (b) Lovering, F. Med. Chem. Commun. 2013, 4, 515. (c) Hann, M. M. Med. Chem. Commun. 2011, 2, 349.

(d) Ritchie, T. J.; Macdonald, S. J. F.; Young, R. J.; Pickett, S. D. Drug Discov. Today 2011, 16, 164. (e) Luker, T.; Alcaraz, L.; Chohan, K. K.; Blomberg, N.; Brown, D. S.; Butlin, R. J.; Elebring, T.; Griffin, A. M.; Guile, S.; St-Gallay, S.; Swahn, B.-M.; Swallow, S.; Waring, M. J.; Wenlock, M. C.; Leeson, P. D. Bioorg. Med. Chem. Lett. 2011, 21, 5673.

(5) Aldeghi, M.; Malhotra, S.; Selwood, D. L.; Chan, A. W. E. Chem. Biol. Drug Des. 2014, 83,450 . 
(6) (a) Blakemore, D. C.; Castro, L.; Churcher, I.; Rees, D. C.; Thomas, A. W.; Wilson, D. M.; Wood, A. Nat. Chem. 2018, 10, 383. (b) Goldberg, F. W.; Kettle, J. G.; Kogej, T.; Perry, M. W. D.; Tomkinson, N. P. Drug Discov. Today 2015, 20, 11.

(7) (a) Ogoshi, S.; Tsutsumi, K.; Kurosawa, H. J. Organomet. Chem. 1995, 493, C19. (b) Baize, M. W.; Blosser, P. W.; Plantevin, V.; Schimpff, D. G.; Gallucci, J. C.; Wojcicki, A. Organometallics 1996, 15, 164. (c) Tsutsumi, K.; Ogoshi, S.; Nishiguchi, S.; Kurosawa, H. J. Am. Chem. Soc. 1998, 120, 1938. (d) Tsutsumi, K.; Kawase, T.; Kakiuchi, K.; Ogoshi, S.; Okada, Y.; Kurosawa, H. Bull. Chem. Soc. Jpn. 1999, 72, 2687.

(8) (a) Tsuji, J.; Mandai, T. Angew. Chem. Int. Ed. Engl. 1995, 34, 2589. (b) Ma, S. Eur. J. Org. Chem. 2004, 1175. (c) Ye, J. T.; Ma, S. M. Acc. Chem. Res. 2014, 47, 989. (d) O'Broin, C. Q.; Guiry, P. J. J. Org. Chem. 2020, 85, 10321.

(9) (a) Tsuji, J.; Watanabe, H.; Minami, I.; Shimizu, I. J. Am. Chem. Soc. 1985, 107, 2196. (b) Minami, I.; Yuhara, M.; Watanabe, H.; Tsuji, J. J. Organomet. Chem. 1987, 334, 225. (c) Koizumi, T.; Sugie, K.; Kiyonaga, O.; Yamanaka, M.; Kawabata, S. Macromolecules 2004, 37, 9670. (d) Nishioka, N.; Koizumi, T. Tetrahedron Lett. 2011, 52, 3662. (e) Nishioka, N.; Koizumi, T. Eur. Polym. J. 2011, 47, 1142. (f) Nishioka, N.; Koizumi, T. J. Polym. Sci., Part A: Polym. Chem. 2011, 49, 642. (g) Schröder, S. P.; Taylor, N. J.; Jackson, P.;

Franckevičius, V. Org. Lett. 2013, 15, 3778. (h) Kenny, M.; Christensen, J.; Coles, S. J.; Franckevičius, V. Org. Lett. 2015, 17, 3926. (i) Kenny, M.; Kitson, D. J.; Franckevičius, V. J. Org. Chem. 2016, 81, 5162. (j) Kenny, M.; Schröder, S. P.; Taylor, N. J.; Jackson, P.; Kitson, D. J.; Franckevičius, V. Synthesis 2018, 50, 1796.

(10) (a) Guo, L.-N.; Duan, X.-H.; Liang, Y.-M. Acc. Chem. Res. 2011, 44, 111. (b) Yoshida, M. Chem. Pharm. Bull. 2012, 60, 285. (c) Yoshida, M. Heterocycles 2013, 87, 1835. (d) Hu, X.-H.; Liu, Z.-T.; Shao, L.; Hu, X.-P. Synthesis 2015, 47, 913. (e) Franckevičius, V.

Tetrahedron Lett. 2016, 57, 3586.

(11) (a) Labrosse, J.-R.; Lhoste, P.; Sinou, D. Tetrahedron Lett. 1999, 40, 9025. (b) Labrosse, J.-R.; Lhoste, P.; Sinou, D. Org. Lett. 2000, 2, 527. (c) Labrosse, J.-R.; Lhoste, P.; Sinou, D. J. Org. Chem. 2001, 66, 6634. (d) Labrosse, J.-R.; Lhoste, P.; Sinou, D. Eur. J. Org. Chem. 2002, 1966. (e) Damez, C.; Labrosse, J.-R.; Lhoste, P.; Sinou, D. Tetrahedron Lett. 2003, 44, 557. (f) Dominczak, N.; Damez, C.; Rhers, B.; Labrosse, J.-R.; Lhoste, P.; Kryczka, B.; Sinou, D. Tetrahedron 2005, 61, 2589. (g) Dominczak, N.; Lhoste, P.; Kryczka, B.; Sinou, D. J. Mol. Catal. A Chem. 2007, 264, 110.

(12) Montgomery, T. D.; Rawal, V. H. Org. Lett. 2016, 18, 740.

(13) Liu, Z.-T.; Hu, X.-P. Adv. Synth. Catal. 2019, 361, 836.

(14) (a) Yoshida, M.; Higuchi, M.; Shishido, K. Tetrahedron Lett. 2008, 49, 1678. (b) Yoshida, M.; Higuchi, M.; Shishido, K. Org. Lett. 2009, 11, 4752. (c) Yoshida, M.; Higuchi, M.; Shishido, K. Tetrahedron 2010, 66, 2675. (d) Yoshida, M.; Sugimura, C.; Shishido, K. Org. Lett. 2011, 13, 3482. (e) Montgomery, T. D.; Nibbs, A. E.; Zhu, Y.; Rawal, V. H. Org. Lett. 2014, 16, 3480. (f) Gao, R.-D.; Liu, C.; Dai, L.-X.; Zhang, W.; You, S.-L. Org. Lett. 2014, 16, 3919. (g) Ding, L.; Ga, R.-D.; You, S.-L. Chem. Eur. J. 2019, 25, 4330. (h) Zhang, Z.-F.; Zhang, Y.; Zhang, C.-L.; Ye, S. Eur. J. Org. Chem. 2020, 2020, 3059.

(15) (a) Duan, X.-H.; Liu, X.-Y.; Guo, L.-N.; Liao, M.-C.; Liu, W.-M.; Liang, Y.-M. J. Org. Chem. 2005, 70, 6980. (b) Yoshida, M.; Sugimura, C. Tetrahedron Lett. 2013, 54, 2082. (c) Yoshida, M.; Nakagawa, T.; Kinoshita, K.; Shishido, K. J. Org. Chem. 2013, 78, 1687. (d) Nibbs, A. E.; Montgomery, T. D.; Zhu, Y.; Rawal, V. H. J. Org. Chem. 2015, 80, 4928. (e) Watanabe, H.; Okubo, M.; Watanabe, K.; Udagawa, T.; Kawatsura, M. Tetrahedron Lett. 2017, 58, 2893. (f) Ding, L.; You, S.-L. Org. Lett. 2018, 20, 6206. (g) Min, X.-L.; Xu, X.-R.; He, Y. Org. Lett. 2019, 21, 9188. (h) Wang, Y. M.; Pritchard, G. J.; Kimber, M. C. Eur. J. Org. Chem. 2020, 2914.

(16) Yoshida, M.; Ohno, S.; Shishido, K. Chem. Eur. J. 2012, 18, 1604. 
(17) (a) van Haaren, R. J.; Goubitz, K.; Fraanje, J.; van Strijdonck, G. P. F.; Oevering, H.; Coussens, B.; Reek, J. N. H.; Kamer, P. C. J.; van Leeuwen, P. Inorg. Chem. 2001, 40, 3363. (b) Labrosse, J.-R.; Lhoste, P.; Delbecq, F.; Sinou, D. Eur. J. Org. Chem. 2003, 2813. (18) Geng, L. F.; Lu, X. Y. J. Chem. Soc., Perkin Trans. 1 1992, 17.

(19) (a) Zhou, Y.; Zhu, F. L.; Liu, Z. T.; Zhou, X. M.; Hu, X. P. Org. Lett. 2016, 18, 2734. (b) Li, K.; Zhu, F.-L.; Liu, Z.-T.; Tong, J.; Hu, X.-P. Org. Biomol. Chem. 2018, 16, 742.

(20) Sjögren, M.; Hansson, S.; Norrby, P.-O.; Åkermark, B.; Cucciolito, M. E.; Vitagliano, A. Organometallics 1992, 11, 3954.

(21) Geng, L.; Lu, X. Tetrahedron Lett. 1990, 31, 111.

(22) Yamakawa, T.; Ideue, E.; Iwaki, Y.; Sato, A.; Tokuyama, H.; Shimokawa, J.; Fukuyama, T. Tetrahedron 2011, 67, 6547.

(23) Details of the X-ray data for $\mathbf{3 3 b}$ and $\mathbf{3 5 a}$ are available in the Supporting Information. These data have been deposited with the Cambridge Crystallographic Data Centre (CCDC 2040606 for 33b and CCDC 2040607 for 35a).

(24) (a) Fournier-Nguefack, C.; Lhoste, P.; Sinou, D. Synlett 1996, 553. (b) Locascio, T. M.; Tunge, J. A. Chem. Eur. J. 2016, 22, 18140. (c) O'Broin, C. Q.; Guiry, P. J. Org. Lett. 2020, 22, 879.

(25) (a) Yoshida, M.; Fujita, M.; Ihara, M. Org. Lett. 2003, 5, 3325. (b) Horino, Y.; Homura, N.; Inoue, K.; Yoshikawa, S. Adv. Synth. Catal. 2012, 354, 828.

(26) Vellalath, S.; Van, K. N.; Romo, D. Angew. Chem. Int. Ed. 2013, 52, 13688.

(27) Lee, H. S.; Kim, D. H. Bull. Korean Chem. Soc. 2002, 23, 593.

(28) Lange, J. H. M.; van Stuivenberg, H. H.; Coolen, H. K. A. C.; Adolfs, T. J. P.; McCreary, A. C.; Keizer, H. G.; Wals, H. C.; Veerman, W.; Borst, A. J. M.; de Looff, W.; Verveer, P. C.; Kruse, C. G. J. Med. Chem. 2005, 48, 1823.

(29) Pitts, M. R.; Harrison, J. R.; Moody, C. J. J. Chem. Soc., Perkin Trans. $12001,955$.

(30) Nolt, M. B.; Smiley, M. A.; Varga, S. L.; McClain, R. T.; Wolkenberg, S. E.; Lindsley, C. W. Tetrahedron 2006, 62, 4698.

(31) Xu, Y.-L.; Qi, J.-M.; Sun, F.-F.; Ma, N. Tetrahedron Lett. 2015, 56, 2744.

(32) Tsuchida, K.; Yuki, M.; Nakajima, K.; Nishibayashi, Y. Chem. Lett. 2018, 47, 671.

(33) Li, R.-Z.; Tang, H.; Yang, K. R.; Wan, L.-Q.; Zhang, X.; Liu, J.; Fu, Z. Y.; Niu, D. W. Angew. Chem. Int. Ed. 2017, 56, 7213.

(34) Zhao, J. B.; Clark, D. A. Org. Lett. 2012, 14, 1668.

(35) Fischer, P.; Schweizer, E.; Langner, J.; Schmidt, U. Magn. Reson. Chem. 1994, 32, 567.

Supplementary Material. Supplementary data to this article can be found online. 